
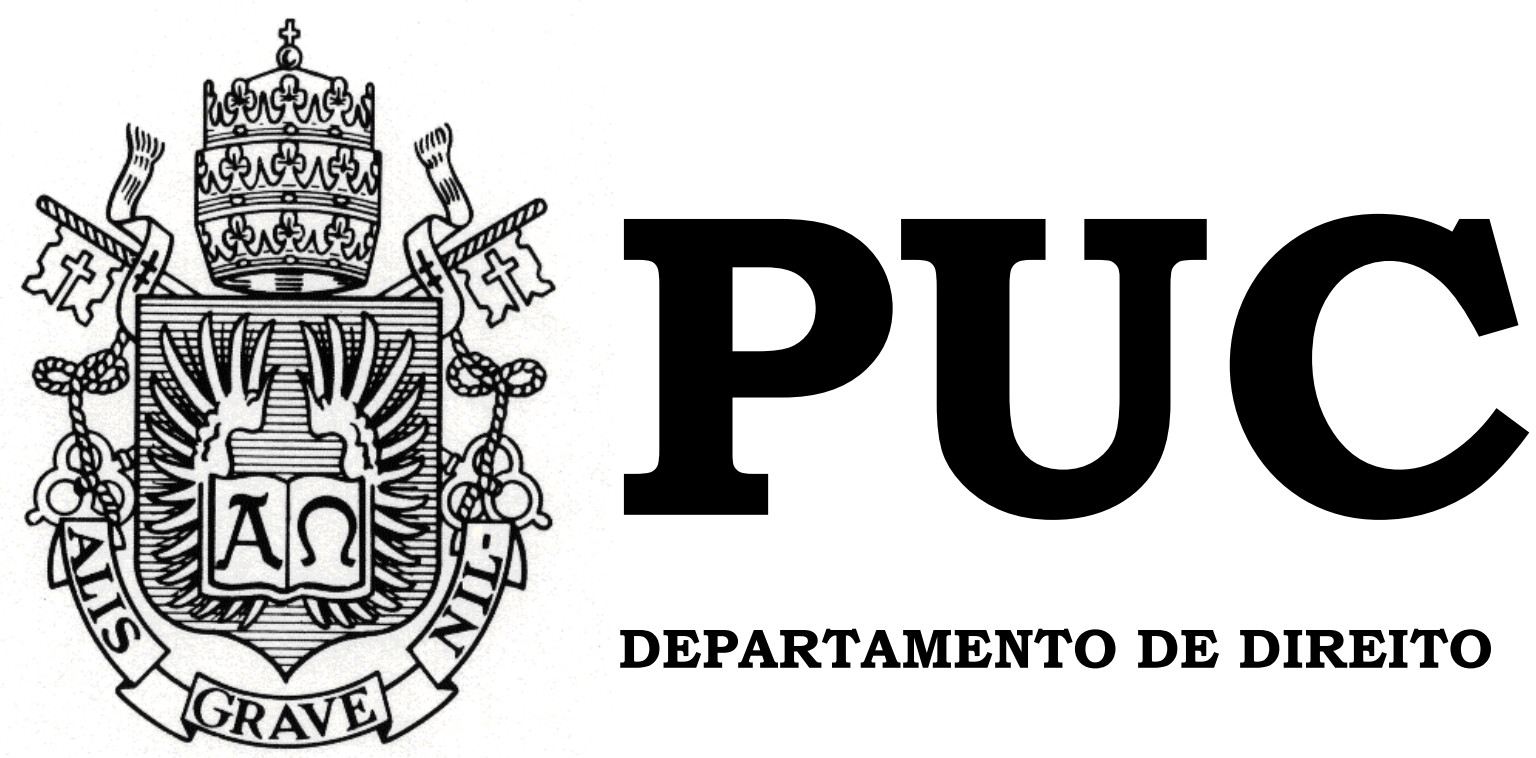

DEPARTAMENTO DE DIREITO

\title{
AS EMPRESAS ESTATAIS COMO CENTROS ECONÔMICOS E A CRISE EM SEU MODELO JURÍDICO
}

\section{Por}

Isabela Schrotke Pires

ORIENTADOR: Marianna Montebello Willeman

PONTIFÍCIA UNIVERSIDADE CATÓLICA DO RIO DE JANEIRO RUA MARQUÊS DE SÃO VICENTE, 225 - CEP 22451-900 RIO DE JANEIRO - BRASIL 


\title{
As Empresas Estatais como centros econômicos e a crise em seu modelo jurídico
}

por

\section{Isabela Schrotke Pires}

\author{
Monografia apresentada ao \\ Departamento de Direito da \\ Pontifícia Universidade Católica do \\ Rio de Janeiro (PUC-Rio) para a \\ obtenção do Título de Bacharel em \\ Direito.
}

Orientadora: Marianna Montebello Willeman 
Dedico este trabalho à minha família, meu porto seguro. À minha mãe, Rosineide Schrotke Pires, ao meu pai, Silvio Cesar Pires, ao meu irmão, Luiz Carlos Schrotke Pires. Agradeço de forma carinhosa pelo apoio e dedicação. 


\section{AGRADECIMENTOS}

De forma sincera, ao encerrar este ciclo importante e essencial, não poderia deixar de agradecer às pessoas que fizeram parte deste caminho, formado por momentos únicos, que me fizeram chegar até aqui mais forte e esperançosa.

Em primeiro lugar agradeço a Deus, pois em todos os momentos recebo sua proteção.

Aos meus pais, Rosineide Schrotke Pires, a pessoa mais doce e amorosa, e Silvio Cesar Pires, o homem mais honesto e guerreiro, sem vocês este momento não estaria se concretizando, devo tudo a vocês. A humildade, a sinceridade, o amor, carinho, honestidade, a forma guerreira de batalhar a cada dia me faz valorizar ainda mais ter chegado até aqui. Além disso, vocês são meus melhores amigos, meu ombro amigo, meu tudo. Saibam que reconheço todas as renúncias que realizaram, e este é somente o início da retribuição que quero proporcionar a vocês.

Agradeço ao meu irmão, meu caçula, uma versão aprimorada dos meus pais e minha, Luiz Carlos Schrotke Pires, pelo o qual nutro o carinho mais puro e o amor mais sincero. Você, que me acompanha diariamente, você, que faz parte de cada momento da minha vida da forma mais especial possível.

Ao meu namorado, João Victor Pereira dos Santos, por todo o amor, paciência, senso de humor implacável, companheirismo, conselhos sinceros, parceria e carinho. Por ser minha segurança nos dias difíceis e meu riso nos dias ensolarados, por me alertar a reclamar menos e agradecer mais. Você me inspira a ser melhor todos os dias, a levar a vida com mais leveza e me apoia em cada sonho, me faz mais forte, soma. Mesmo depois desse tempo todo, meu amor e admiração por você só aumentam. 
À minha grande família, avós Lidia e Maria, madrinha e padrinho, tias e tios, primas e primos, que considero irmãs e irmãos, que mesmo com a distância, mantêm-se presentes em meu coração.

Às minhas amigas, que são as mais sinceras, divertidas, me fazem realizar que a vida sempre pode, e deve ser mais leve. Sejam as que me acompanham desde sempre, ou as que ganhei como presente ao longo da vida, vocês possuem um lugar especial e sou iluminada por poder desfrutar da companhia de cada uma.

Aos profissionais que contribuíram para que eu obtivesse a certeza de que eu estou na profissão certa, e que demonstram a cada dia enorme integridade em suas atitudes, além do amor pelo Direito. Reinaldo Frederico Afonso Silveira, meu ilustre chefe na Procuradoria Geral do Estado do Rio de Janeiro, e Inês Alegria Rocumback, que foi uma segunda mãe em muitos momentos, na Pontifícia Universidade Católica do Rio de Janeiro. Obrigada por terem concedido ensinamentos que durarão para o resto da minha vida.

Por fim, e de forma significativa, gostaria de agradecer à Marianna Montebello Willeman, seja como minha brilhante professora de Direito Administrativo na Pontifícia Universidade Católica do Rio de Janeiro, seja como orientadora desta monografia. Devo meu apreço a este ramo do Direito, por ter tido você como professora. Tenha certeza que você inspira muitos alunos e alunas a serem competentes e excepcionais, assim como você é. Agradeço pela incrível oportunidade de ter sido orientada por você, pela confiança e aprendizado. 


\section{RESUMO}

PIRES, Isabela Schrotke. As Empresas Estatais como Centros Econômicos e a Crise em seu Modelo Jurídico. Rio de Janeiro: 2017. X p. Monografia (Graduação em Direito). Pontifícia Universidade Católica do Rio de Janeiro - PUC-Rio.

O presente trabalho possui o objetivo de analisar a relevância econômica que as empresas estatais exercem no contexto nacional. Além disso, pretende expor o modelo jurídico das mesmas a partir de uma averiguação crítica, por se dizer estar em crise. Intenciona-se realizar uma análise profunda da jurisprudência do Supremo Tribunal Federal, visto que o posicionamento da Corte se tornou decisivo para os rumos que foram tomados. Por meio da análise jurisprudencial, da legislação e da captura do posicionamento doutrinário, foi possível entender que a concessão de privilégios autárquicos às Empresas Estatais prestadoras de serviço público acarretou demasiada confusão em sua própria identidade, o que proporciona disfunções pontuais, tais como o anseio, advindo das Empresas Estatais, por outras prerrogativas que anteriormente eram concedidas somente à Fazenda Pública. Além de prejudicar a sua própria flexibilidade com relação ao mercado de livre iniciativa. Ademais, a presente pesquisa considera os efeitos da guinada jurisprudencial do Supremo Tribunal Federal que refletiram diretamente na Lei $\mathrm{n}^{\circ}$. 13.303 de 30 de julho de 2016, pois que este novo estatuto jurídico possuiu o intuito de unificar os regimes jurídicos. A partir da análise em todas as esferas, sejam elas jurisprudenciais, doutrinárias e legislativas, o presente trabalho propõe-se a apontar soluções a fim de que a crise no modelo jurídico das estatais seja subjugada.

Palavras-Chave: Direito Administrativo. Regime jurídico. Empresas Estatais. Estrutura Societária. Empresa Pública. Sociedade de Economia Mista. Serviço público. Atividade econômica. Autarquização. Jurisprudência. Supremo Tribunal Federal. Backlash. 


\section{SUMÁRIO}

INTRODUÇÃO .......................................................................................... 8

CAPÍTULO 1 - AS EMPRESAS ESTATAIS COMO CENTROS

ECONÔMICOS ............................................................................................ 11

1.1. A estrutura societária das Empresas Estatais .................................... 11

1.1.1. O fortalecimento da governança corporativa............................. 15

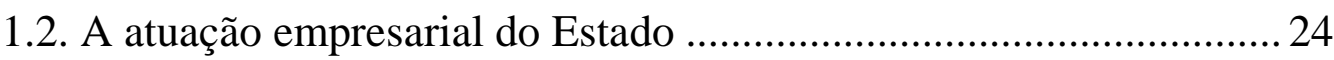

1.3. A função pública inerente às Empresas Estatais e a busca pela

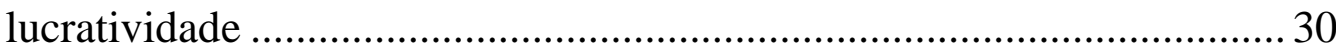

CAPÍTULO 2 - O COLAPSO DO REGIME JURÍDICO DAS

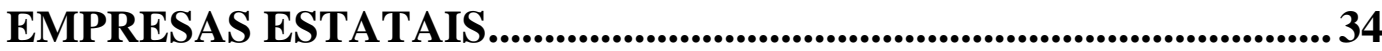

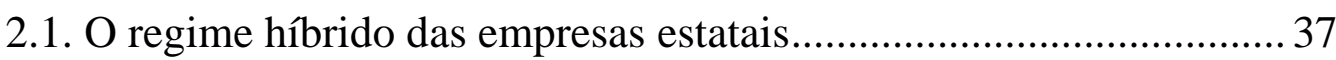

2.2. Espécies de atividades econômicas (lato sensu): serviços públicos, monopólios públicos, serviços públicos sociais e atividades econômicas (stricto sensu) do art. 173 da Constituição Federal .................................... 40

2.3. Tendência autarquizante do Supremo Tribunal Federal e a problemática dos privilégios às empresas estatais prestadoras de serviço público 46

2.3.1 Implicações do artigo 150, parágrafo $3^{\circ}$ da Constituição Federal no regime tributário 47

2.3.2. As estatais prestadoras de serviços públicos e seu regime de execução. 53

CAPÍTULO 3 - A CRISE DE IDENTIDADE DAS EMPRESAS

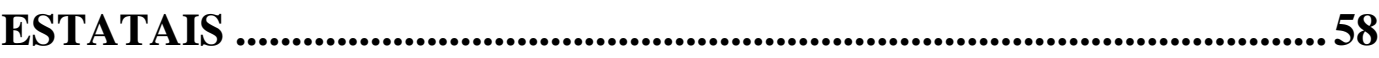

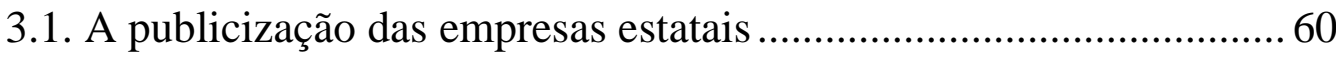

3.1.1. A jurisprudência do Supremo Tribunal Federal e o backlash .. 66 3.2. O controle exercido pelos órgãos de controle nas Empresas Estatais 71 
3.3. O advento do novo estatuto jurídico - A Lei $\mathrm{n}^{\circ} .13 .303$ de 30 de julho de 2016 e a tentativa de uniformização dos regimes jurídicos das

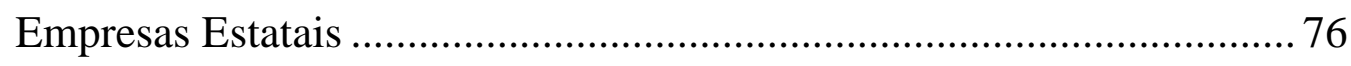

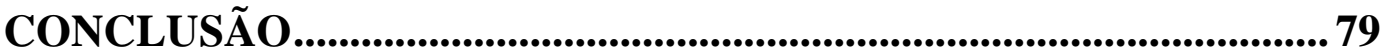

REFERÊNCIAS BIBLIOGRÁFICAS .................................................... 81 


\section{INTRODUÇÃO}

O presente trabalho visa estudar o contexto socioeconômico em que as Empresas Estatais se encontram na atual conjuntura. Constata-se a ocorrência do backlash ${ }^{1}$ à jurisprudência do Supremo Tribunal Federal, no sentido de que passou a ser aplicado às Empresas controladas pelo Estado, o regime autárquico, o que prejudica em vários sentidos sua competição com o mercado, além de desqualificar seus serviços prestados.

O primeiro capítulo desta monografia possui o intuito de esclarecer a estrutura societária, na qual as empresas estatais estão inseridas. Estuda-se aqui as mais diversas formas de aplicação do controle estatal e sua convivência com o mercado de capitais, estruturas como o conselho de administração, o papel dos acionistas majoritários e minoritários, além de significar a relevância da efetiva governança corporativa nas Empresas Estatais.

O segundo capítulo propõe-se a expressar a dicotomia existente no regime das empresas estatais, ou seja, a influência direta do direito privado e do direito público. Começamos pela descrição do gênero atividades econômicas, que como um todo, engloba a prestação de serviços públicos. Ainda, mencionamos a tendência autarquizante do Supremo Tribunal Federal, por meio de suas decisões, e a forma como vem aplicando isso ao

\footnotetext{
${ }^{1}$ Marianna Montebello Willeman, em seu artigo "Constitucionalismo Democrático, Backlash E Resposta Legislativa Em Matéria Constitucional No Brasil", expôs a relevância do efeito do backlash no país, ou seja, a notoriedade que as decisões judiciais vêm adquirindo, da seguinte forma: "A tradição constitucional que reconhece a supremacia judicial em matéria de interpretação constitucional confere grande relevo às reações e às consequências que podem advir de uma decisão judicial a respeito do significado de Constituição. Esse é um fator de extrema importância nas equações a serem solucionadas perante as cortes de justiça, especialmente porque, a depender do grau de reação à decisão judicial, o próprio poder judiciário pode ser chamado a ter que reafirmar sua autoridade interpretativa". Explica ainda que tal conceito é trazido do direito norte-americano: "A doutrina norte-americana estuda esse fenomeno conferindo-lhe a etiqueta de backlash, usualmente associado, para os fins ora em apreciação, aos efeitos indesejados, contraprodutivos ou adversos que podem ser gerados por uma decisão judicial em matéria constitucional".

WILlEMAN, Marianna Montebello. Constitucionalismo Democrático, Backlash e Resposta Legislativa em Matéria Constitucional no Brasil. 33ª ed. REDE. p. II-5, jan/fev/mar 2013.
} 
regime tributário e ao de execução, neste pincelando o regime de bens no que tange à impenhorabilidade dos mesmos.

O terceiro capítulo objetiva expor a forma como a jurisprudência do Supremo Tribunal Federal influenciou negativamente a atuação das Empresas Estatais no Brasil. Mesmo existindo normas constitucionais, tais como o artigo 150 e 173 da Constituição da República Federativa do Brasil. Ainda, expondo como a jurisprudência vem tratando sobre o controle externo nas empresas estatais, principalmente no que tange ao controle exercido pelos Tribunais de Contas, e pincelando o controle pelo poder legislativo e executivo. Por último, visamos comentar de forma abrangente e geral o novo Estatuto das Estatais, a Lei ${ }^{\circ} 13.303$ de 2016, que visa uniformizar os regimes e busca, o que podemos falar que seria uma forma de backlash, preservar o caráter empresarial das empresas estatais.

De todo modo, a solução para a problemática da aplicação do regime autárquico às empresas estatais, seria a mudança de entendimento da Corte. Faz-se necessário que as Estatais realmente atuem de forma competitiva e relevante no mercado, não somente captando lucro, mas perseguindo o interesse público de forma consciente e eficaz, e isto se dá de forma efetiva se elas estiverem aptas a competirem diretamente com o mercado privado. Não somente isso, se mesmo não competindo, que a própria prestação de serviços públicos esteja devidamente protegida, não somente seu patrimônio.

A finalidade da pesquisa, de nenhuma forma, seria a elaboração de um tratado sobre as empresas estatais, esgotando assim todos os assuntos referentes à mesma. Pelo contrário, o que se busca é a realização crítica de uma análise dos aspectos empresarias de gerenciamento estatal, assim como o direcionamento para a problemática existente na jurisprudência do Supremo Tribunal Federal no que tange a aplicação do regime público a estas empresas. 
O objetivo visado será a defesa da existência de uma premente necessidade de modificar o entendimento atual do Supremo Tribunal Federal, consolidado por meio de sua jurisprudência, e isso irá ocorrer a partir de um diálogo institucional entre os poderes Executivo e Legislativo.

Cabe assim dizer, portanto, que o intuito aqui presente é o de criticar a maneira como o Supremo Tribunal Federal vem aplicando os privilégios às empresas estatais. Em outras palavras, está afastando-as de sua natureza empresarial e, simultaneamente, as tornando próximas a um modelo autárquico, de pessoa jurídica de direito público, que é distinto do que ela realmente é.

Por isso, os regimes a serem analisados serão os que influenciaram esta mudança de paradigma da Corte, após isto se busca expor possíveis soluções para esta problematização, o que envolveria um trabalho de convencimento de que as empresas estatais devem ser vistas como centros econômicos, configura-se, assim, necessário que seja respeitado seu viés empresarial ${ }^{2}$.

\footnotetext{
${ }^{2}$ A fim de que seja realizada uma pesquisa aprofundada sobre os temas que envolvam as empresas estatais, seu regime, seja ele licitatório, contratual, pessoal, orçamentário, de bens, de responsabilidade civil, falimentar, processual administrativo, tributário, societário, recomenda-se a leitura de Alexandre Santos de Aragão (ARAGÃO, 2017, p. 161). O autor busca contextualizar historicamente a trajetória das empresas estatais, além de expor caminhos viáveis e eficazes para a atuação do Estado na economia. Neste sentido, o autor Mario Engler Pinto Junior (PINTO JUNIOR, Mario Engler, 2010) possui a obra denominada "Empresa Estatal: função econômica e dilemas societários". Nesta obra ele realiza uma análise minuciosa das questões societárias que envolvem as empresas estatais e analisa seu papel no âmbito econômico.
} 


\title{
CAPÍTULO 1 - AS EMPRESAS ESTATAIS COMO CENTROS ECONÔMICOS
}

O Estado intervém no domínio econômico, ou seja, desempenha suas funções empresariais por meio das Empresas Estatais, e isso se torna necessário, mesmo nas sociedades de livre concorrência, visto que muitas vezes a criação de Empresas Estatais foi associada a grandes crises financeiras enfrentadas pela sociedade, ou até mesmo para dar início ao desenvolvimento industrial. De acordo com Abranches:

\begin{abstract}
As empresas estatais surgem como elemento novo, estrutural e politicamente determinado, para garantir a continuidade e ampliação do processo de acumulação privada de capital. (...), não são nem resultado inexorável de determinações estruturais irresistíveis, nem produto da ideologia, da afirmação autoritária e voluntarista de um projeto estadista de elites bem situadas na estrutura de poder. São produto de respostas políticas a problemas estruturais ${ }^{3}$.
\end{abstract}

As Empresas Estatais possuem objetivos que contendem entre si, um deles é a obtenção de lucratividade, a fim de que possa competir livremente no mercado em regime de igualdade com as empresas privadas, outro é sua função intrínseca, que seria a persecução do interesse público. Desse modo, será necessário contemplar a estrutura societária das Empresas Estatais, a fim de que seja possível compreender sua vocação original.

\subsection{A estrutura societária das Empresas Estatais}

O presente tópico será pautado na exposição geral, sem que sejam esgotados, pois fugiria ao escopo da pesquisa, dos alicerces da estrutura societária, que são o controle acionário e os órgãos de administração da companhia, pois por meio de ambos o Estado poderá exercer seu controle.

\footnotetext{
3 ABRANCHES, Sérgio Henrique. A empresa pública como agente de políticas do Estado: Fundamentos Teóricos do seu Papel, Inclusive em Face de Nossas Relações com o Exterior. In: Seminário sobre empresas estatais. A empresa pública no Brasil: uma abordagem multidisciplinar. Brasília: IPEA, 1980. p. 4-5.
} 
A Lei $n^{0}$ 6.404/76, especificamente em seu artigo $116^{4}$ buscou identificar o acionista controlador como àquele que instrui a companhia a cumprir sua função social, sendo que o que detém o poder de controle responde em sua pessoa pelos danos causados por todo abuso praticado no poder.

Isso se explica, de acordo com Comparato e Salomão Filho, que o acionista controlador possui atribuições e deveres específicos no que tange à companhia em que exerce o controle. Segundo eles:

Na economia da nova sociedade anônima, o controlador se afirma como seu mais recente órgão, ou, se preferir a explicação funcional do mecanismo societário, como titular de um novo cargo social. Cargo, em sua mais vasta acepção jurídica, designa um centro de competência envolvendo uma ou mais funções. $\mathrm{O}$ reconhecimento de um cargo, em qualquer tipo de organização, faz-se pela definição de funções próprias e necessárias. Ora, tais funções existem vinculadas à pessoa do controlador, pelo menos do acionista controlador. No vigente direito acionário brasileiro, elas podem resumir-se no poder de orientar e dirigir, em última instância, as atividades sociais ${ }^{5}$.

O acionista controlador da companhia possuirá deveres e obrigações, independente da caracterização de controle majoritário ou minoritário, basta que sua situação de fato seja minimamente estável. Assim sendo, para que pratique atos, como Pinto Junior menciona, é necessário que a estabilidade seja garantida por sua posição:

Já para outros efeitos previstos na lei do acionariato, como a obrigatoriedade da realização de oferta pública no caso de alienação do controle acionário de companhia aberta (art. 245-A), a condição de acionista controlador pressupõe um mínimo de estabilidade que somente pode ser conferido pela posição jurídica ${ }^{6}$.

\footnotetext{
${ }^{4}$ Entende-se por acionista controlador a pessoa, natural ou jurídica, ou o grupo de pessoas vinculadas por acordo de voto, ou sob controle comum, que a) é titular de direitos de sócio que lhe assegurem, de modo permanente, a maioria dos votos nas deliberações da assembleia-geral e o poder de eleger a maioria dos administradores da companhia; e b) usa efetivamente seu poder para dirigir as atividades sociais e orientar o funcionamento dos órgãos da companhia. Parágrafo único. $\mathrm{O}$ acionista controlador deve usar o poder com o fim de fazer a companhia realizar o seu objeto e cumprir sua função social, e têm deveres e responsabilidades para com os demais acionistas da empresa, os que nela trabalham e para com a comunidade em que atua, cujos direitos e interesses deve lealmente respeitar e atender.

${ }^{5}$ SALOMÃO FILHO, Calixto. Regulação e desenvolvimento. In: SALOMÃO FILHO, Calixto (Org.). Regulação e desenvolvimento. São Paulo: Malheiros Editores, 2002.

${ }^{6}$ PINTO JUNIOR, Mario Engler. Empresa Estatal: função econômica e dilemas societários. $2^{\mathrm{a}}$ ed. São Paulo: Atlas, 2013. p. 340.
} 
O nível mais elevado de decisão interna de uma companhia é a denominada assembleia geral, traduzida como o controle interno, em que as matérias são submetidas à votação dos acionistas da companhia, para que sejam aprovadas ou rejeitadas. As deliberações resultantes das assembleias gerais de cada companhia são, principalmente, resultantes da maioria das ações com direito a voto.

Pinto Junior certifica que, atualmente, o poder do acionista controlador é exercido de maneira a alinhar intuitivamente os administradores da própria companhia a si, existe uma relação, que ele denomina ser de fidelidade, realiza assim, uma crítica relevante:

A fidelidade dos gestores sociais à pessoa do acionista controlador responsável por sua eleição é mais evidente quando há facilidade de substituição imediata. Tudo isso produz o esvaziamento da assembleia geral como locus para manifestação do poder de controle, compreendendo a discussão e tomada de decisões relevantes sobre as atividades empresariais ${ }^{7}$.

Nessa mesma linha de raciocínio, Comparato afirma que as assembleias gerais são meros instrumentos do capitalismo:

\begin{abstract}
Ninguém mais contesta hoje em dia que a assembleia anual das grandes companhias transformou-se num dos mais sofisticados exercícios de ilusão popular do capitalismo. Por trás da liturgia democrática, tanto mais elaborada quanto menos correspondente à realidade do poder econômico, surge o governo 'endocrático' como disse um autor americano, ou o 'despotismo esclarecido' como lembrou Ripert ${ }^{8}$.
\end{abstract}

\title{
Confere ainda um caráter 'meramente formal' às mesmas:
}

Na pesquisa da realidade do poder, na sociedade anônima, não nos podemos contentar com a afirmação legal de que a 'assembleia geral, convocada e instalada de acordo com a lei e o estatuto, tem poderes para decidir todos os negócios relativos ao objeto da sociedade e tomar as resoluções que julgar convenientes à sua defesa e desenvolvimento' (Lei $\mathrm{n}^{\mathrm{o}}$ 6.404, art. 212). Quem toma, de fato, as decisões em assembleia? O controle manifesta-se através dos poderes decisórios da assembleia de acionistas como necessária legitimação do seu exercício. Mas essa legitimação é meramente formal ou procedimental. [...] Ora, ao controlador, mais do que a qualquer dos participantes na sociedade, compete o dever de atuar em vista da realização dessa finalidade [lucrativa]; não

\footnotetext{
${ }^{7}$ PINTO JUNIOR, 2013, p. 342.

${ }^{8}$ COMPARATO, Fabio Konder. Aspectos Jurídicos da Macroempresa. São Paulo: Revista dos Tribunais, 1970. p. 20-21.
} 
só pelo exercício do voto, mas também fora da assembleia, definindo a política empresarial e promovendo sua aplicação pelo órgão administrativo 9 .

Eizirik concorda ao declarar que as companhias estão passando por um processo de "esvaziamento da assembleia geral", justamente devido ao fato de que se tornou uma manifestação do acionista controlador, e os administradores e outros acionistas procuram seguir suas exteriorizações:

Verificamos, presentemente, no entanto, um gradual 'esvaziamento' da assembleia geral como o 'locus' onde se exterioriza, de fato, a manifestação do poder de controle. Ainda que legalmente continue a ser o órgão que expressa a vontade social, seus poderes vêm sendo 'transferidos' cada vez mais para o conselho de administração, nas companhias abertas, assim como para a chamada 'reunião prévia' dos acionistas integrantes de acordo de acionistas, que se caracteriza como órgão não institucionalizado, mas de fundamental importância no processo decisório das companhias que apresentam uma estrutura de controle compartilhado $^{10}$.

O acionista controlador elege a maior parte dos administradores da companhia, então é certo que entre eles exista uma relação de confiança recíproca, por isso é defendido por alguns autores que o destino da companhia estaria nas mãos do acionista controlador. No entanto, Fabio Konder Comparato e Calixto Salomão Filho ${ }^{11}$ discordam deste ponto, pois segundo eles a influência decisiva ainda assim é a assembleia geral.

O artigo 238 da Lei das S.A. ${ }^{12}$ ampara o Estado como acionista controlador. Certo é que seus deveres são mais amplos do que o de um acionista controlador privado, e a missão pública não deve estar vinculada

\footnotetext{
${ }^{9}$ COMPARATO, Fábio Konder; SALOMÃO FILHO, Calixto. O Poder de Controle na Sociedade Anônima (com Salomão Filho, Calixto). $4^{\mathrm{a}}$ ed. São Paulo: Editora Forense, 2005. p. 32, 39, 382.

${ }^{10}$ EIZIRIK, Nelson et al.. Mercado de Capitais: Regime Jurídico. São Paulo: Renovar, 2008. p. 365.

11 "Afigura-se discutível, no entanto, que esse poder de eleger a maioria dos administradores coincida com a essência do poder de controle. É verdade que, nas companhias inglesas, a assembleia geral tem poderes expressos nos estatutos e o board a competência residual, e que, nos Estados Unidos, os administradores têm até mesmo o poder de declarar dividendos. Mas, no direito brasileiro, a competência privativa dos administradores (arts. 142 e 144) não lhes dá o poder supremo na companhia, relativamente à assembleia geral".

COMPARATO, Fábio Konder; SALOMÃO FILHO, Calixto. O Poder de Controle na Sociedade Anônima (com Salomão Filho, Calixto). $4^{\mathrm{a}}$ ed. São Paulo: Editora Forense, 2005. p. 86. In: PINTO JUNIOR, Mario Engler. Empresa Estatal: função econômica e dilemas societários. $2^{a}$ ed. São Paulo: Atlas, 2013. p. 361.

12 Art. 238. A pessoa jurídica que controla a companhia de economia mista tem os deveres e responsabilidades do acionista controlador (artigos 116 e 117), mas poderá orientar as atividades da companhia de modo a atender ao interesse público que justificou a sua criação.
} 
somente ao seu papel como controlador, mas ser inerente ao funcionamento da companhia.

Quando falamos em conselho de administração, falamos em eleição dos administradores pelo acionista controlador. A fim de que a busca pela concretização do interesse público seja realmente efetiva, é necessário que este conselho seja composto por pessoas diversas daquelas que partilham uma mesma visão política ou que já conheçam e tenham relação de fidúcia prévia com o controlador estatal.

Cabe assim dizer, portanto, que uma companhia criada por meio de lei autorizativa e que possui o Estado como acionista controlador, deve perseguir a consecução do interesse público. Iremos ver a seguir a importância do alinhamento entre os dirigentes, gestores, e o controlador da companhia, que se resume em uma alinhada governança corporativa. Além disso, o tópico 1.2., que concerne à 'atuação empresarial do Estado', debruçar-se-á sobre a questão aqui já suscitada acerca do conselho de administração, além de falar sobre o Estado ser controlador, mesmo que detenha menos da metade da participação acionária.

\subsubsection{O fortalecimento da governança corporativa}

A governança corporativa pode ser considerada como conjunto de instituições que ordena o trato entre os gestores e investidores, e tal perspectiva é seguida pela $\mathrm{OECD}^{13}$. Um modo criticado de se dizer governança, porém utilizado no meio empresarial e também entre os operadores de direito, seria afirmar que é um anglicismo da expressão corporate governance ${ }^{14}$.

\footnotetext{
${ }^{13}$ OECD - Organisation for Economic CO-operation and Development. Corporate governance in development: the experiences of Brazil, Chile, India, and South Africa. Paris: OECD Development Centre, 2003. p. 3-4.

${ }^{14}$ Corporate governance possui como correspondente na língua portuguesa, a denominada governança corporativa.

OCDE - Organização para a Cooperação e Desenvolvimento Econômico. Corporate Governance of Stateowned Enterprises. A Survey of OECD Countries. p. 36. Disponível em:
} 
Pinto Junior define 'instituições' como: “o conceito de instituições abrange leis, regulamentos, normas estatutárias, disposições contratuais, códigos de ética e conduta, e práticas negociais" ${ }^{\prime 15}$.

Os investimentos realizados na companhia poder ser diversos, tais como utilizar a mão de obra dos empregados, equipamentos, clientes, consumidores, aporte de capital dos acionistas sem que se espere retorno financeiro, realização de empréstimo bancário. Ou seja, acarretam demasiada robustez à companhia.

No entanto, a maior preocupação acerca da governança corporativa, seria a de que os dirigentes da companhia, que são aqueles que detêm o poder de decisão, passassem a atuar de acordo com as conveniências dos investidores e não no interesse próprio da companhia.

Com o passar do tempo e realizações de experiências empíricas, foi possível certificar que as companhias que possuem uma boa governança corporativa atraem investidores por serem consideradas mais estáveis, trazem maior segurança ao investimento nela realizado, até porque inexiste relação contratual entre o acionista investidor e a companhia em si. Justamente por isso, diz-se que o acionista não controlador seria essencialmente importante para a governança corporativa, sendo ele considerado o beneficiário do fluxo de caixa residual gerado pela companhia, o denominado 'residual claimant ${ }^{16}$ '.

Mario Engler ${ }^{17}$, em consonância com a doutrina estrangeira ${ }^{18}$, afirma que é existente uma desarmonia entre os administradores e os acionistas, o

<http://www.keepeek.com/Digital-Asset-Management/oecd/governance/corporate-governance-ofstate-owned-enterprises_9789264009431-em>. Acesso em: 18 mai. 2017.

${ }^{15}$ PINTO JUNIOR, 2013, p. 61.

${ }^{16}$ A expressão 'residual claimant', a qual não possui um correspondente em português para definila, possui o intuito de expressar que o acionista não controlador recebe, sendo caracterizado como beneficiário, do fluxo de caixa residual gerado pela companhia.

17 "A principal preocupação com a eficiência da empresa estatal reside na dificuldade de minimizar custos de produção, tendo em vista a falta de critérios adequados de avaliação de desempenho e de sistema de incentivos para alinhamento dos interesses pessoais dos administradores com a missão pública atribuída à companhia, combinada com a discricionariedade permitida aos mesmos administradores para justificar o resultado afinal obtido". 
que é ampliado pelas assimetrias informacionais entre ambos. Os administradores possuem conhecimento da real situação da companhia, assim como de informações que não são acessíveis aos acionistas, e isto é denominado de problema de agência.

O problema de agência ${ }^{19}$ seria exatamente os interesses em conflito, ocorre quando as decisões dos administradores não resistem às consequências econômicas que delas advém, ou por serem decisões que cumpram o que está disposto legalmente, porém não seria a atitude mais adequada para a companhia em si. Decisões essas que não são necessariamente ilícitas, mas que configurem situações pessoais privilegiadas ou questões corporativistas.

Vale mencionar o posicionamento doutrinário que expressa tais tomadas de decisões serem influenciáveis de tal modo, tendo como justificativa a natureza humana, tal como Smith defendia:

Há quem enxergue o problema de agencia como sendo algo inerente à própria natureza humana, que tende a agir sempre de forma individualista, sem levar em conta as consequências para o ambiente coletivo. Essa visão apoia-se na racionalidade econômica do liberalismo clássico, que tem origem na obra de Adam Smith ${ }^{20}$.

PINTO JUNIOR, Mario Engler. Estado como acionista controlador. Tese de Doutorado. Orientador: Prof. Calixto Salomão Filho. Faculdade de Direito da USP, 2009. p. 61.

${ }^{18}$ Yair Aharoni, conforme segue Mario Engler, afirma que existe certa dificuldade no que tange ao controle do desempenho das empresas estatais. As alternativas para tornar viável tal controle, segundo o autor, são as seguintes: “(i) verificação quanto ao efetivo atendimento dos objetivos assinalados à empresa estatal; (ii) a realização de auditoria social para apurar o nível de satisfação material e moral dos consumidores, a elevação do padrão de vida da população, a melhoria na distribuição de renda, as externalidades sociais produzidas; e (iii) a comparação (benchmarking) com o histórico passado da companhia. O autor lembra ainda que a ausência de tais estudos tem levado os administradores de companhias públicas a invocarem os custos dos objetivos sociais que lhes são assinalados, como desculpa para justificar a ineficiência da gestão empresarial".

AHARONI, Yair. The Evolution and Management of State Owned Enterprises (Ballinger Series in Business and Public Policy). Ballinger Pub Co - September, 1986. p. 52.

19 Mario Engler explica, em sua dissertação "Estado como acionista controlador", que o pior desempenho da empresa estatal está associado ao problema de agência, que é, segundo ele: "característico das empresas de capital pulverizado e sem acionista controlador definido, em que os administradores (agentes) agem de forma descompromissada com a maximização do bem estar dos acionistas (principais) (...)".

PINTO JUNIOR, 2009, p. 59.

${ }^{20}$ SMITH, Adam. An inquiry into the nature and causes of the wealth of nations. Cambridge: Hackett publishing Company, 1993. p. 188. 
Pinto Junior apresenta a redução do problema de agência, no caso das sociedades anônimas, que seria a retirada dos administradores e sua substituição por outros que visem a ampliação do lucro daquela companhia de forma mais efetiva. $O$ óbice presente em relação a primeira saída apresentada, seria a necessidade de uma reunião de votos suficientes na assembleia geral para eleição de novos administradores. Vale ressaltar que se a base acionaria desta companhia for dispersa, será mais dificultoso seguir por este caminho.

Se, no caso, a companhia valer mais para quem está comprando do que o oposto, a tomada hostil de controle da companhia se torna mais acessível, principalmente nas companhias de capital pulverizado, também se as ações desta companhia localizam-se no mercado nas mãos de acionistas empenhados em sua venda.

A tomada hostil de controle suscita apreensão por parte dos administradores, empregados e outros terceiros vinculados àquela companhia. Isto ocorre, porque existem dois estilos de acionistas que poderão assumir o controle, ser um acionista consciente do histórico da companhia, que respeite o passado da mesma, ou um financista capaz de inovar e redefinir todos os quadros desta companhia. De toda forma, o que irá assumir o controle, na maioria das vezes, busca gerenciar melhor os gastos e enxugar os quadros de empregados, inclusive renova o quadro de administradores da empresa.

Devido à insegurança que a tomada hostil proporciona, tal passou a ser delimitada em meados de 2000, por meio de recursos estatutários, tais como as poison pills ${ }^{21}$, constituency statutes ${ }^{22}$, e em casos como este, o

\footnotetext{
${ }^{21} \mathrm{O}$ autor Mario Engler Pinto Junior define poison pills como mecanismo de defesa adotado pelo estatuto social daquela companhia, a fim de que se evite a "mudança involuntária de controle daquela companhia". PINTO JUNIOR, 2013, p. 366.

${ }^{22} \mathrm{Da}$ mesma forma que define poison pills, o autor acima referido também descreve constituency statutes como possuindo a mesma função que as poison pills, seriam mecanismos de defesa inseridos no estatuto social a fim de proteger o controle daquela companhia. BAINBRIDGE, Stephen M. Interpreting nonshareholder constituency statutes. Pepperdine Law Review. v. 19, 1992. p. 991-1025. Disponível em: <http://ssrn.com/abstract=310261>. Acesso em:
} 
administrador da companhia deverá aceitar pessoalmente sua constituição. Esses recursos, por assim dizer e pelas consequências que dele advêm, transformam a tomada hostil de controle em tomada amigável.

No caso de ser a companhia uma public corporation ${ }^{23}$, o problema de agência passou a ser encarado como uma motivação aos administradores para concentrarem seus trabalhos em prol dos acionistas. Visto que ao atender os interesses dos acionistas, será vantajoso para a companhia em dois aspectos cruciais, tal como expressa Pinto Junior:

$\mathrm{O}$ atendimento ao interesse patrimonial dos acionistas possui duplo viés, sendo um de curto prazo (apuração de lucros máximos em cada exercício social) e outro de mais longo prazo (valorização do investimento acionário), que, por sua vez, vincula-se à cotação da ação na bolsa de valores; a evolução do preço de bolsa reflete normalmente a geração de valor ao acionista, na medida em que incorpora a expectativa de resultados futuros ${ }^{24}$.

Existem formas de ampliar o interesse dos administradores por meio de medidas que aprimoram a rentabilidade da companhia. Estas seriam tentativas de alinhar o interesse dos administradores ao dos acionistas, uma delas seria a remuneração variável a ser designada aos administradores, determinada de acordo com as respostas recorrentes expressas no balanço da companhia, por meio de bônus anuais ou a outorga de opção de compra de ações - denominada stock options ${ }^{25}$.

A opção de compra de ações faz com que os administradores não se posicionem de forma imediatista diante do mercado, eles poderiam por meio da opção de compra de ações, obter ações diretamente da companhia

12 jan. 2007. In: PINTO JUNIOR, Mario Engler. Empresa Estatal: função econômica e dilemas societários. $2^{\text {a }}$ ed. São Paulo: Atlas, 2013. p. 491.

23 As empresas prestadoras de serviços públicos são conhecidas como utilities. As public corporations seriam companhias que não possuem um acionista controlador definido, seu capital é pulverizado mediante ofertas públicas. Segundo Mario Engler Pinto Junior, as public corporations corresponderiam a "à companhia com base acionária diluída e sujeita ao controle gerencial".

${ }^{24}$ PINTO JUNIOR, 2013, p. 66.

${ }^{25}$ As stock options são uma forma de remuneração variável por meio da outorga da opção de compra de ações, Mario Engler Pinto Junior as define: "Aprofundou-se a prática de estipular remuneração variável aos administradores, atrelando-a aos resultados periódicos da companhia expressos no balanço, sob a forma de pagamento de bônus anuais ou mediante a outorga de opção de compra de ações".

Ibid., p. 81. 
por um valor preestabelecido, que corresponde a cotação vigente no momento da concessão da opção. Os administradores possuirão ganho se as ações se valorizarem no futuro, pois estariam exercendo a opção de compra pagando um preço menor ao existente no mercado.

A fim de evitar que ocorram deformidades graves na estrutura da companhia, é necessário que a governança corporativa possua em si elucidações acerca do controle interno estrutural da companhia, além de dominar a prática de incentivar economicamente a companhia.

Pode-se dizer que as companhias de controle concentrado e as de capital pulverizado enfrentam problemáticas distintas quando se fala em problema de agência. Nas de controle concentrado, a "relação agenteprincipal" ocorre entre o controlador e os outros acionistas, não entre os acionistas e administradores. Em decorrência disto, o administrador deixa de ter a independência funcional que seria inerente a sua função, pois que a decisão final passa pelo crivo do acionista controlador.

Em casos como o acima mencionado, muitas vezes, o administrador possui um alinhamento de interesses próximo aos do acionista controlador, por ter sido indicado pelo mesmo, ou por possuir uma relação pessoal próxima. Geralmente, a ruptura entre os dois ocorre a partir do momento em que o acionista controlador solicita que o administrador pratique algum ato que extrapole os limites legais, visto que quem se responsabilizaria pessoalmente pelas consequências seria o administrador da companhia.

Além dos conflitos já explicitados, existem aqueles concernentes a função do acionista controlador e os acionistas minoritários, denominado problema de expropriação, que seria o ato de controlador se expropriar dos fundos da companhia, despojando os demais acionistas. Em contraposição a tal pensamento, alguns autores ${ }^{26}$ afirmam que o controlador poderia ser

\footnotetext{
${ }^{26}$ GILSON, Ronald J. Controlling shareholders and corporate governance: complicating the comparative taxonomy (Aug. 2005). ECGI - Law Working Paper, n. 49. Disponível em: <http://ssrn.com/abstract=784744>. Acesso em: 03 abr. 2017.
} 
positivo para a companhia, pois seria a figura do "chefe", supervisionando de forma apurada os atos dos administradores.

Uma das formas do acionista controlador enriquecer de forma ilícita à custa da companhia em que ele exerce o controle seria por meio da transação com partes relacionadas, visto que, se as partes tiverem uma ligação com o controlador, ele terá realmente se apropriado do fluxo de caixa da companhia, mas pode ser que ocorra apenas um negócio mal realizado, se for o caso em que parte não possua vínculo com o acionista controlador.

Para solucionar o problema de expropriação, foi necessário aprimorar a prática da governança corporativa a fim de equalizar o tratamento entre o controlador e os acionistas minoritários, a fim de evitar conluio entre o controlador e os administradores.

É possível afirmar que as empresas estatais possuem falhas conjugadas características das empresas de controle concentrado, e também de capital pulverizado. A problemática latente é identificada ao passo que o Estado busca viabilizar o interesse político por meio da companhia, o que, muitas vezes, frustra a expectativa dos investidores privados.

O Estado, muitas vezes, passa a exercer o papel de controlador de maneira não competente no sentido de ser capaz para fiscalizar os administradores da empresa, o que é caminho aberto para que os administradores não alinhem seus interesses aos dos objetivados pelo Estado. Tal situação é caracterizada como 'grave' por Pinto Junior, pelo fato de:

(...) a empresa estatal não ter como única finalidade a geração de lucros, servindo também como instrumento de políticas públicas. Tudo isso acaba favorecendo o corporativismo e impactando negativamente o resultado da companhia, além de desviar o foco da missão pública que justificaria a manutenção da propriedade acionária estatal ${ }^{27}$.

\footnotetext{
${ }^{27}$ PINTO JUNIOR, 2013, p. 71.
} 
É preciso dizer que existe a possibilidade dúctil de o Estado, como acionista controlador público, causar prejuízos ao patrimônio da empresa por meio da expropriação. Isto ocorre caso pratique o denominado clientelismo político ou se conduzir a companhia no sentido de que cumpra finalidades macroeconômicas que não estejam alinhadas ao seu estatuto social, o que prejudica diretamente o cumprimento de sua função pública.

Não se pode olvidar que, na sociedade anônima comum, existe a apreensão de captura das vantagens privadas do controle, como por exemplo, o despojo de acionistas minoritários por parte do acionista controlador estatal, ou o abuso praticado pelo Estado no que tange às transações com partes relacionadas, estas sendo outras empresas estatais.

Tenha-se presente que as empresas estatais que não se encontram em concorrência com o mercado privado, é recomendável que esteja configurada como companhia aberta listada em bolsa de valores, a fim de evitar ineficiência estatal em seu controle.

É inegável que as empresas estatais em concorrência com o mercado privado reduzem suas ineficiências internas, pois que os investidores privados irão demandar a produção de resultados, o que produz um efeito competitivo. No caso, o ideal seria o modelo de duopólio, a empresa estatal não possuir propriedade empresarial somente pública ou somente privada, mas sim dividir o mercado com outra companhia privada.

Cumpre assinalar que o Estado possui preferência por lidar com investidores de mercado, do que com investidor típico de private equity ${ }^{28}$.

\footnotetext{
${ }^{28}$ Private equity seria o aporte de recursos em empresas já bem desenvolvidas, em processo de consolidação de mercado, para ajuda-las a se preparar para abrir capital, fundir-se ou serem adquiridas por outras grandes empresas.

Guia da Associação Brasileira de Private Equity \& Venture Capital. Disponível em: <http://www.abvcap.com.br/Download/Guias/2726.pdf>. Acesso em: 19 mai. 2017.

"Infusion of private equity also helps subject the company to some degree of market monitoring and discipline. It focuses boards and management on producing shareholder value, as opposed to the pursuit of 'political' objectives, and may foster greater transparency by imposing disclosure requirements on the company".

OECD - ORGANISATION FOR ECONOMIC CO-OPERATION AND DEVELOPMENT. Privatizing state-owned enterprises: an overview of policies and practices in OECD Countries.
} 
Isto se dá porque o investidor de mercado está interessado em resultados financeiros apenas, já os investidores de private equity costumam se interessar pelas decisões fundamentais da companhia, interferindo, muitas vezes, nas políticas públicas a serem tomadas pelo controlador estatal.

A partir do momento em que o Estado procura obter acesso ao mercado de capitais, se submetendo ao convívio comum com as empresas privadas, principalmente no que tange ao disclosure ${ }^{29}$, a forma mais utilizada pelo Estado para converter a empresa pública unipessoal em sociedade de economia mista é a oferta pública de ações.

$\mathrm{O}$ acesso ao mercado de capitais expande as fontes de financiamento, atrai maiores recursos para as empresas estatais, além de passar a emitir valores mobiliários representativos de dívida, os quais não estão subordinados à ação regulatória. Além disso, a empresa estatal se submete à fiscalização e controle da Comissão de Valores Mobiliários (CVM), podendo sofrer sanções se praticarem alguma infração.

Os benefícios decorrentes do acesso ao mercado de capitais para as empresas estatais são inúmeros, tais como a venda de ações de titularidade estatal que excedem seu poder de controle, o que retorna como reforço ao orçamento público de forma a facilitar o cumprimento de sua função social. Neste contexto, o Estado deverá cumprir austeramente as matérias que tangem a governança corporativa, como afirma Pinto Junior:

Quando a empresa estatal recorre ao mercado de capitais por meio de oferta pública primária ou secundária de ações, afigura-se justificável a assunção de compromissos mais rigorosos em matéria de governança corporativa, tanto por parte dela própria quando do ente público controlador. A concessão de vantagens políticas e patrimoniais aos acionistas de mercado ingressantes, além daquelas já

Paris: OECD Publications, 2003. p. 114. In: PINTO JUNIOR, Mario Engler. Empresa Estatal: função econômica e dilemas societários. $2^{\text {a }}$ ed. São Paulo: Atlas, 2013. p. 90.

${ }^{29}$ Mario Engler Pinto Junior afirma que: "No fundo, a obrigação de disclosure equivale a uma forma de controle social sobre a macroempresa que faz apelo à poupança popular". PINTO JUNIOR, 2013, p. 328.

SALOMÃO FILHO, Calixto. Sociedade anônima: interesse público e privado. Interesse Público. v. 5, n. 20, jul. Belo Horizonte, 2003. p. 19. 
asseguradas por lei, têm por objetivo tornar mais atraente o investimento e valorizar o preço de subscrição ${ }^{30}$.

O desafio dual da empresa estatal encontra-se entre a busca por lucro e o cumprimento do interesse público, pois que a expectativa de recebimento de regresso financeiro do mercado de capitais é latente a companhia.

\subsection{A atuação empresarial do Estado}

No caso das empresas estatais, o Estado configura-se como acionista controlador de determinada companhia. Por ser controlador da companhia, busca ordenar a mesma com o interesse público que é inerente a sua atuação. Assim sendo, deverá utilizar seu direito de voto durante as assembleias gerais para que possa exercer seu comando, deliberar sobre políticas públicas, assim como expressa o artigo 238 da Lei das S.A. ${ }^{31}$.

Comparato e Franco ao comentar o disposto no artigo acima mencionado, afirmam que por mais que esteja escrito o verbo 'poderá' no texto do artigo, não seria viável interpretar a orientação da companhia para que atenda ao interesse público como uma mera faculdade do acionista controlador, o Estado:

Quando a lei, portanto, dispõe que a pessoa jurídica que controla a sociedade de economia mista 'poderá orientar as atividades da companhia de modo a atender ao interesse público que justificou sua criação', ela está expressando um dever, não uma permissão. Temos, aí, um dos frequentes casos em que o verbo 'poder' significa, tecnicamente, 'dever', como foi salientado pela melhor doutrina hermenêutica. O Estado-acionista não pode, sob pena de incorrer em ilegalidade e inconstitucionalidade, deixar de atender às exigências do interesse público que justificaram a criação da sociedade de economia mista, a fim de satisfazer o interesse econômico dos acionistas privados ${ }^{32}$.

\footnotetext{
${ }^{30}$ PINTO JUNIOR, 2013, p. 75.

31 A pessoa jurídica que controla a companhia de economia mista tem os deveres e responsabilidades do acionista controlador (artigos 116 e 117), mas poderá orientar as atividades da companhia de modo a atender ao interesse público que justificou a sua criação.

${ }^{32}$ COMPARATO, Fábio Konder. Sociedade de economia mista transformada em sociedade anônima ordinária - inconstitucionalidade. Revista trimestral de direito público. Instituto Internacional de Direito Público. Instituto de Direito Administrativo Paulista. São Paulo: Malheiros Editores, 1993. p. 63.
} 
A norma do artigo 238 da atual lei das sociedades anônimas apresenta, paradoxalmente, a realização do interesse público como uma faculdade e não como um dever atribuído ao controlador. Diz-se paradoxalmente, porque, se o critério legitimador da intervenção na economia é o interesse público, ditado por razoes de ordem econômica, políticas e sociais, tendo em vista a realização do bem-estar coletivo e se um destes foi o fundamento da criação da sociedade anônima de economia mista, tal como decorre do próprio texto da lei (art. 238), a persecução daquele interesse deveria ser obrigatória e não facultativa ${ }^{33}$.

\title{
Outra forma do Estado exercer seu controle nas Empresas Estatais é
} por meio dos seus órgãos de administração, e isso se dá por meio da eleição dos administradores que atuem de acordo com a orientação estatal, conforme elucida Pinto Junior:

\begin{abstract}
A relação de fidúcia que o acionista controlador mantem com os administradores por ele eleitos configura modalidade de influência dominante sobre os desígnios da companhia. A influência dominante decorre de uma situação de fato, e não propriamente de uma relação jurídica. Como na sociedade de economia mista o conselho de administração possui existência obrigatória, o conceito de maioria dos administradores para efeito de caracterizar o exercício do poder de controle significa mais da metade dos cargos preenchidos naquele órgão societário. Os diretores, por sua vez, são escolhidos por votação do conselho de administração, e não por indicação direta do Estado enquanto acionista controlador. Já a capacidade de eleger a maioria no conselho fiscal não é prerrogativa necessária do titular do controle, pois não se enquadra na categoria de administrador da companhia. O Estado não pode dispensar a influência legitima sobre o comportamento dos conselheiros de administração eleitos com a forca do voto majoritário, que formam - ou deveriam formar - um grupo coeso, capaz de atuar de modo coordenado nos limites de sua competência institucional, para assegurar a gestão da companhia seja a o mesmo tempo eficiente e comprometida com o interesse público que justificou sua criação ${ }^{34}$.
\end{abstract}

$\mathrm{O}$ Estado exerce seu poder de comando em relação às Empresas Estatais de maneira mais ampla, se comparado ao poder de comando de um acionista controlador privado. Isto motivado pelo fato de que deverão ser atendidos os interesses de terceiros, os outros acionistas, além de atentar para o cumprimento do interesse público da companhia.

A fim de que seja concedida maior autonomia para o conselho de administração da própria companhia, será necessário que os componentes espelhem os interesses dos receptores da atividade pública a ser executada

33 FRANCO, Vera Helena de Mello. Direito Empresarial: Sociedade Anônima. Mercado de Valores Mobiliários. v. 2. São Paulo: Revista dos Tribunais, 2014. p. 138-184.

${ }^{34}$ PINTO JUNIOR, 2013, p. 343-344. 
pela companhia. Tal objetivo será alcançado a partir do momento em que sejam consideradas pessoas integrantes da sociedade, que possam realmente perseguir a concretização do interesse público, e isto poderá ser feito por pessoas consideradas 'desobrigadas'.

O interesse público não deve ser encarado como apontamento restrito ao acionista controlador, que no caso em tela é o Estado, pelo contrário, deve ser considerado como o próprio interesse da sociedade de economia mista. Assim sendo, o conselho de administração estará legitimado a buscar sua concretização, mesmo que não haja manifestação do acionista controlador estatal. Assim como Pinto Junior esclarece: “A identificação e consecução do interesse público não constituem tarefas exclusivas do titular do controle acionário, mas objetivo comum compartilhado por todos os acionistas e responsáveis pela gestão social”35.

Ainda na seara do conselho de administração, o posicionamento doutrinário administrativo não possui a tendência extrema de considerar que o mesmo poderia ser totalmente autônomo a fim de realizar políticas públicas independente do poder de controle acionário. Se assim fosse, o poder acionário estatal seria esvaziado por atos desconexos do conselho de administração.

No que tange ao controle minoritário exercido pelo Estado em algumas companhias, pode-se dizer que mesmo ao deter a minoria do capital votante, é possível que, sozinho, exerça o controle de comando. Este tipo de controle ocorre a partir do momento em que as ações estejam pulverizadas no mercado de capitais, e somente o Estado possa unir os votos a fim de que aprove assuntos específicos que sejam definidos pela assembleia geral.

Pinto Junior afirma que não existem questionamentos acerca da companhia que possui o controle minoritário estatal integrar ou não a administração pública, pois:

\footnotetext{
${ }^{35}$ PINTO JUNIOR, 2013, p. 364.
} 
A conclusão nesse particular depende da legislação própria de cada esfera de governo, que pode exigir o requisito da maioria absoluta do capital votante, ou se contentar com outro tipo de influência dominante, para determinar quando uma companhia com participação acionaria estatal passa a integrar a chamada administração indireta. Não é demais lembrar que a Constituição Federal utiliza as expressões empresa pública e sociedade de economia mista, porém, sem defini-las ${ }^{36}$.

No entanto, a dúvida que é suscitada, e já respondida de maneira afirmativa pelo autor, reside no fato de que a excepcionalidade como trata a Lei das S.A., ao tornar menos rígida a busca pelo lucro, a fim de que seja atendido o interesse público, o qual é seu objeto intrínseco, aplicar-se-ia nos casos das companhias que são detidas por um controle minoritário do Estado.

Estável ou não, inequívoco ou não, o controle minoritário exercido pelo Estado poderá se deparar com desafios no que tange às ações em circulação e suas ofertas de aquisição. Não há como negar que a preferência é de um controle estável, a fim de evitar uma mudança de controle da companhia para uma entidade privada. Pinto Junior destaca uma forma de relativizar tal problematização exposta:

Para minimizar a ameaça de mudança involuntária no comando da companhia, nada impede que o estatuto social adote mecanismos legítimos de preservação da dispersão acionária, sem prejuízo de outros remédios específicos em decorrência da natureza estatal do empreendimento. O controle minoritário estável configura posição jurídica devidamente consolidada, e não apenas situação de fato transitória ${ }^{37}$.

Carvalhosa ${ }^{38}$, no entanto, em desacordo com a corrente que afirma que o estatuto social da companhia deveria conter dispositivos para preservar o controle estatal contra provável dispersão acionária, que é o que Mario Engler Pinto Junior defende. Afirma que as denominadas poison

\footnotetext{
${ }^{36}$ PINTO JUNIOR, 2013, p. 347-348.

${ }^{37}$ Ibid., p. 347-348.

${ }^{38}$ CARVALHOSA, Modesto. As poison pills estatutárias na pratica brasileira - alguns aspectos de sua legalidade. In: CASTRO, Rodrigo R. Moteiro de; ARAGÃO, Leandro Santos de (Coord.). Direito societário: desafios atuais. São Paulo: Quartier Latin, 2009. p. 20-29.
} 
pills $^{39}$ seriam controversas ao serem aplicadas no Brasil, justamente por delimitar uma imposição aos acionistas, impedindo que a liberdade seja exercida dentro da companhia.

É importante ressaltar que, mantendo o mesmo ponto de vista, a Comissão de Valores Mobiliários - CVM, em seu Parecer de Orientação no 36, de 23 de julho de $2009^{40}$, expressou-se no sentido de que essas cláusulas sejam acrescentadas no estatuto social. A CVM defende a liberdade do exercício do direito de voto e na soberania da assembleia geral.

Uma forma de garantir estabilidade ao controle minoritário estatal seria a exiguidade de acionistas considerados 'rivais' e a sua condição permanente ao deter o controle. Desta feita, considerando que o controle estatal a ser exercido seja o minoritário ou majoritário, deve ter ele aspecto incondicional, de modo que a discricionariedade do Estado não venha a ser delimitada no momento em que estiver direcionando as atividades da companhia com o intuito de perseguir o cumprimento de sua finalidade pública.

A partir do momento em que o Estado exerce o comando irrestrito da sociedade de economia mista, reduz a possibilidade da existência de controle compartilhado, que significaria a presença e aquiescência de um sócio estratégico a fim de tomar decisões relevantes. Frise-se que isso não inibe a efetivação de um acordo de $\operatorname{acionistas}^{41}$ ou a inserção de cláusulas

\footnotetext{
${ }^{39}$ Da mesma forma que define poison pills, o autor acima referido também descreve constituency statutes como possuindo a mesma função que as poison pills, seriam mecanismos de defesa inseridos no estatuto social a fim de proteger o controle daquela companhia.

BAINBRIDGE, 1992, p. 991-1025 In: PINTO JUNIOR, 2013, p. 491.

${ }^{40}$ Disposições estatutárias que impõem ônus a acionistas que votarem favoravelmente à supressão de cláusula de proteção à dispersão acionária.

Diário Oficial da União. 29 jun. 2009. Disponível em:

<http://www.cvm.gov.br/legislacao/pare/pare036.html>. Acesso em: 31 mar. 2017.

${ }^{41}$ Cabe aqui dizer que, contrariamente a esta corrente, Celso Antônio Bandeira de Mello, defende que as sociedades de economista não deveriam realizar, em hipótese alguma, acordo de acionistas, além de defender a inflexibilidade do controle acionário pelo Estado, conforme expressa: "Com efeito, o que se quer é, precisamente, garantir que seu controle absoluto, que a condição de seus destinos, seja estritamente da alçada do Estado ou de suas criaturas auxiliares, sem que possa repartir decisões, sejam quais forem, sobre qualquer assunto social com particulares. (...) Assim, é da mais solar evidencia, que sociedades de economia mista não podem, sob pretexto algum, efetuar acordos de acionistas, por via dos quais fiquem outorgados aos acionistas minoritários poderes que lhes ensejem conduzir ou embargar a livre condução da empresa por parte daqueles
} 
estatutárias para que se confiram prerrogativas aos possuidores de ações preferenciais.

Sundfeld segue Pinto Junior no sentido de apoiar a denominada 'parceria estratégica' entre a sociedade de economia mista e o sócio privado. Como forma de viabilizar a parceria entre ambos, explica que:

\begin{abstract}
Não há impropriedade no reconhecimento, a sócios minoritários de empresas de economia mista, de direitos de que decorram condicionamentos aos poderes do acionista estatal. Ao submeter-se à forma empresarial - e é disso que se trata nas sociedades mistas - o Estado conscientemente opta por um modelo de organização em que, à diferença do autárquico, seus poderes de controle, conquanto existentes e necessários, serão condicionados, à vista das necessidades de composição de interesses. [...] Se o Estado deixar totalmente de influir na entidade, ela não mais servirá como instrumento de ação administrativa, perderá o caráter de empresa estatal, extinguindo-se, portanto, a personalidade governamental. Daí a necessidade de autorização legislativa. Mas se o Estado, dentro das virtualidades próprias da condição de acionista, realizar mudanças na estruturação social, sem deixar de estar presente na empresa e mantendo o vínculo desta para com as políticas públicas que justificam sua existência, ela então persistira sendo uma empresa estatal dotada de personalidade governamental. A medida independera da citada autorização ${ }^{42}$.
\end{abstract}

No mesmo sentido, Alexandre dos Santos de Aragão expressa seu apoio aos denominados 'parceiros estratégicos', afirmando que o Estado, por meio de suas sociedades de economia mista, deverá agir de forma flexível, como forma de atraí-los e aumentar sua eficiência e competitividade no mercado:

Dentro dessa lógica de atuação cada vez mais próxima do mercado, pautada pela busca de aperfeiçoamento e eficiência, o Estado pode, como forma de atrair os assim chamados "parceiros estratégicos", mitigar o exercício desse controle, seja através dos inúmeros instrumentos negociais de direito societário, como os acordos de acionistas e regras especiais constantes do estatuto social, como, também, através da adoção unilateral e voluntária de standards de governança corporativa $^{43}$.

que são, ex vi legis, majoritários precisamente para terem mãos desatadas no concernente a isto". MELLO, Celso Antônio Bandeira de. Curso de Direito Administrativo. $28^{a}$ ed. São Paulo: Malheiros Editores, 2011. p. 194-195.

42 SUNDFELD, Carlos Ari. A participação privada nas empresas estatais. In: Direito administrativo econômico. São Paulo: Malheiros Editores, 2000. p. $273,282$.

${ }^{43}$ ARAGÃO, Alexandre dos Santos de. Empresas Estatais. Rio de Janeiro: Forense. VitalBook file, 2017. p. 422. 
Cumpre dizer que defendemos a corrente de que o controle estatal poderá ser mitigado, seja por meio do acordo de acionistas ou adesão à Bolsa ${ }^{44}$. O objetivo é que este mecanismo de expressão da vontade do Estado se torne mais efetivo e competitivo juntamente ao mercado privado, e como já dito anteriormente, não prejudicará o interesse público que é objeto social da mesma.

\subsection{A função pública inerente às Empresas Estatais e a busca pela lucratividade}

Existe grande discussão acerca do interesse público presente nas empresas estatais e a busca pela maior lucratividade. Atualmente, pode-se afirmar que as sociedades de economia mista vêm possuindo dificuldade no que tange à identificação própria, seu verdadeiro papel socioeconômico.

É nítido que existe uma dualidade de objetivos da empresa estatal, que seria a consecução do lucro e ao mesmo tempo, a busca pelo cumprimento da finalidade a qual foi criada. Ambas não se anulam, Comparato, inclusive expressa que o fim lucrativo é inerente à caracterização da sociedade anônima:

Constitui objeto da sociedade anônima, diz o art. $2^{\circ}$, 'qualquer empresa de fim lucrativo'. A norma apresenta duas grandes linhas de eficácia. Em primeiro lugar, proíbe a constituição de sociedade anônima para gerir organizações que não tenham por mira produzir e distribuir lucros entre os seus membros, ao contrário do que pode suceder, por exemplo, nos direitos inglês, norte-americano ou alemão ocidental. Em segundo lugar, institui esse objeto de lucro como parâmetro aferidor da responsabilidade dos administradores e do acionista controlador, perante os demais acionistas e titulares do direito de participação em resultados. A lei veda, aliás, compreensivelmente, aos administradores 'praticar ato de liberalidade à custa da companhia (art. 154, p. 1', 'a'). O lucro constitui, pois, o

\footnotetext{
${ }^{44}$ Defendido por Mario Engler Pinto Junior, e o segue Alexandre dos Santos de Aragão: “Andou bem Mario Engler Pinto Junior ao defender a viabilidade dos compromissos assumidos por sociedades de economia mista para se adaptarem às exigências de adesão aos segmentos especiais da Bolsa. "O efeito mais consistente ao longo do tempo, para a sociedade de economia mista, que passa a fazer parte do Novo Mercado, reside no seu fortalecimento institucional". Por este motivo, "a companhia aumenta o grau de proteção contra eventuais desmandos do acionista controlador, criando barreiras para seu uso com fins políticos, que tantos males já provocou ao contribuinte no passado". PINTO JUNIOR, 2010, p. 72 In: ARAGÃO, 2017, p. 423.
} 
fim ou objetivo legal da sociedade, estreitamente ligado ao seu objeto, que é a atividade empresarial definida estatuariamente ${ }^{45}$.

Difícil seria conceituar o interesse público ${ }^{46}$ no que tange à função empresarial do Estado. A distinção que se destaca seria o interesse da coletividade e o interesse estatal, pois ambos poderiam ser classificados como interesse público.

O interesse da coletividade e o interesse do estado são expressões frequentemente utilizadas como interesse público primário e interesse público secundário ${ }^{47}$. O interesse público secundário seria aquele que funcionaria como requisito para o atendimento do interesse primário, que deveria sempre prevalecer caso haja um confronto entre ambos.

Já o interesse público primário $^{48}$ pode ser equiparado ao interesse coletivo presente no artigo 173 da CRFB, deve ser considerada a missão da empresa estatal por si só. É importante reconhecer que a sociedade de economia mista deve visar o interesse público secundário dos aparelhos estatais, e que o conceito de interesse público aplicado às empresas estatais

\footnotetext{
${ }^{45}$ COMPARATO, Fabio Konder. A reforma da empresa. Revista de Direito Mercantil, Industrial, Econômico e Financeiro. Nova Série, a. 22, n. 50, p. 63, abr./jun. 1983.

${ }^{46}$ Mario Engler Pinto Junior destaca que: "Não se trata, porém, de qualquer interesse público, mas apenas daquele previsto na lei autorizativa da constituição da companhia, reproduzido no estatuto social e compatível com seu campo de atuação".

PINTO JUNIOR, 2010, p. 337.

${ }^{47}$ De acordo com Marçal Justen Filho, o Estado e os particulares possuem interesses distintos, a administração pública não existe para satisfazer egoisticamente seu interesse, mas para satisfazer o interesse público. Neste sentido, Celso Antonio Bandeira de Mello afirma que "o interesse público deve ser conceituado como o interesse resultante do conjunto dos interesses que os indivíduos pessoalmente têm quando considerados em sua qualidade de membros da Sociedade e pelo simples fato de o serem". Ainda, explicita que o Estado possui interesses primários e secundários, assim como os particulares, ou seja, àqueles se encaixam no conceito puro de interesse público, já os secundários seriam os interesses da administração pública, propriamente ditos. Expressa tal ideia inspirada no renomado autor italiano Renato Alessi: "Não iguais, segundo o ilustre doutrinador, porque os particulares podem defender tais interesses intrínsecos à sua personalidade, quando bem entenderem, enquanto que o Estado somente os poderá tutelar quando não forem contrários ao dito interesse público primário e quando com este possuírem coesão. Renato ALESSI possui o mesmo entendimento quando elucida "(...) os interesses secundários do Estado só podem ser por ele buscados quando coincidentes com os interesses primários, isto é, com os interesses públicos propriamente ditos".

MELLO, Celso Antonio Bandeira. Curso de Direito Administrativo. 15ª ed. São Paulo: Malheiros Editores, 2002. p. 53.

48 "La peculiaridad de la posición jurídica de la Administración pública radica precisamente en esto, en que su función consiste en la realización del interés colectivo, público, primário". ALESSI, Renato. Institucines de Derecho Administrativo. Tomo I. Traducción dela $3^{\text {a }}$ edición italiana por Buenaventura Pellisé Prats. Barcelona: Bosch, Casa Editorial, 1970. p. 183.
} 
deve priorizar a dimensão institucional sem ser confundida com o interesse do estado em função de sua linha política.

As autoridades governamentais utilizam as empresas públicas como estratégias para alcançar sua finalidade pública e assim sendo, concretizá-la. O foco das políticas públicas não é satisfazer o interesse econômico, mas sim a adoção de políticas coordenadas que visem a obtenção de resultados para a ordem jurídica.

As políticas públicas por si só não objetivam atingir a eficiência econômica, também não se ajustam ao conceito de eficiência, elas demandam que sejam realizadas ponderações entre os interesses coletivos e os individuais a razão pela qual não precisam ser comprometidas com a eficiência, ou ser produtiva.

De toda forma, analisa-se que o direito societário busca harmonizar os objetivos acima expostos. O Estado não possui poderes ilimitados para utilizá-los com a finalidade cumprir o interesse público, e ao mesmo tempo, os acionistas minoritários se expõem ao risco de perder patrimônio de forma não compensável.

Neste sentido, Pinto Junior esclarece que:

O conflito decorrente da dualidade de objetivos da empresa estatal (interesse público e finalidade lucrativa) não se resolve mediante a sobreposição incondicional de um sobre o outro. O lucro não é assegurado em qualquer circunstância, mas também não deve ser definitivamente suprimido. $\mathrm{O}$ acionista privado que decide participar de uma companhia mista vinculada à persecução do interesse público não tem garantia de rentabilidade mínima e nem sequer certeza de recuperar o valor do capital inicialmente investido. A expectativa de lucro pode ser alterada a qualquer momento pela vontade unilateral do Estado, embora dentro de determinados limites ${ }^{49}$.

De acordo com Carolina Barros Fidalgo, a lucratividade baixa ou até mesmo sua ausência pela empresa estatal não significa que não é eficiente, pois que o objetivo da mesma não pode ser única e exclusivamente a busca pelo lucro.

${ }^{49}$ PINTO JUNIOR, 2013, p. 355. 
A aparente inferioridade da empresa estatal, quando comparada com a empresa privada, pode ser atribuída ao fato de priorizar a execução de políticas públicas em detrimento da maximização dos lucros, e não necessariamente à menor capacidade técnica e operacional. Evidências empíricas mostram que a exposição à concorrência de mercado tende a ser mais efetiva para mudar o comportamento empresarial, do que simplesmente a substituição do controlador público pelo privado. Foi constatado também que a empresa estatal tem condições de responder adequadamente às restrições orçamentárias, realizando ajustes internos para redução de custos e melhoria de produtividade ${ }^{50}$.

Cabe assim dizer que o objeto das empresas estatais é por si distinto do das empresas privadas. Sua busca deverá ser por cumprir seu objeto social, sendo eficaz no sentido produtivo, sem que esta eficiência seja exclusivamente econômica. Sendo necessário, portanto, que exista um diálogo entre ambos os interesses no sentido de gerar resultados produtivos utilizando-se de forma mínima os recursos disponíveis.

${ }^{50}$ PINTO JUNIOR, Mario Engler. Empresa Estatal: função econômica e dilemas societários. $2^{\mathrm{a}}$ ed. São Paulo: Atlas, 2013. p. 57. In: FIDALGO, Carolina Barros. O Estado empresário: regime jurídico das tradicionais e novas formas de atuação empresarial do estado na economia brasileira. Rio de Janeiro. 2012. 370 f. p. 166. Dissertação de Mestrado em Direito - Faculdade de Direito, Universidade do Estado do Rio de Janeiro, 2012. 


\title{
CAPÍTULO 2 - O COLAPSO DO REGIME JURÍDICO DAS EMPRESAS ESTATAIS
}

As empresas estatais expressam a atitude volitiva do Estado em criar uma pessoa jurídica de direito privado, que caracteriza o denominado, 'Estado empresário'. As normas que irão incidir sobre essas empresas serão próprias e não aplicáveis às companhias privadas, isto é um dos fatores que torna as empresas estatais um fenômeno jurídico de considerável relevância. Aragão denota a natureza das Estatais da seguinte forma:

\begin{abstract}
Como as estatais são instrumentos da exploração do Estado de atividades econômicas, devemos lembrar que, com exceção dos monopólios públicos e serviços públicos, que já são atividades econômicas de titularidade do próprio Estado, ele só pode explorar as demais atividades econômicas nos casos de exigência de segurança nacional ou de relevante interesse coletivo (art. 173, caput, $\mathrm{CF} / 88$ ), expressão daquilo que constitui, para a maioria da doutrina, o chamado princípio da subsidiariedade da intervenção do Estado na economia: o Estado só pode atuar como agente econômico quando for absolutamente necessário, em face da impossibilidade de os interesses públicos em jogo poderem ser atendidos pela iniciativa privada, e essa atuação (repise-se, com as exceções dos serviços e monopólios públicos) não pode excluir a atuação em igualdade de condições com a iniciativa privada ( art. 173, § $\left.1^{\circ}, \mathrm{II}\right)^{51}$.
\end{abstract}

A natureza empresarial das estatais ${ }^{52}$ não vem sendo considerada diante da jurisprudência e últimas orientações jurídicas, que seguem no sentido de capturar o regime das estatais para o direito público ${ }^{53}$, inclusive as prestadoras de serviço público.

É latente a dificuldade ao se pensar nas Empresas Estatais como centros econômicos, lidar com sua origem societária e simultaneamente a isto, inseri-la no contexto do Direito Público.

\footnotetext{
${ }^{51}$ ARAGÃO, Alexandre Santos de. Curso de Direito Administrativo. $2^{\mathrm{a}}$ ed. rev. atual. e ampl. Rio de Janeiro: Forense, 2013. p. 122.

${ }^{52}$ Expressão extraída do título do trabalho de Carlos Ari Sundfeld e Rodrigo Pagani de Souza, Licitação nas Estatais: Levando a Natureza Empresarial a Sério.

SUNDFELD, Carlos Ari; SOUZA, Rodrigo Pagani de. Licitação nas Estatais: Levando a Natureza Empresarial a Sério. In: Revista de Direito Administrativo. ${ }^{\circ}$ 245, 2007. p. 13.

${ }^{53}$ SILVA, Rodrigo Crelier Zambão da. A captura das estatais pelo regime jurídico de Direito Público: algumas reflexões. p. 237 In: ARAGÃO, Alexandre Santos de (Coord.). Empresas públicas e sociedades de economia mista. $1^{\mathrm{a}}$ ed. Belo Horizonte: Fórum, 2015. p. 302.
} 
Há que se dizer sob as empresas estatais incidem as normas pertinentes às empresas privadas, não somente isto, normas que se aplicam às estatais em sua generalidade, como também normas que se aplicam somente àquela estatal. Pinto esclarece melhor este ponto da seguinte forma:

O Estado empresário é um fenômeno complexo e merecedor de estudos jurídicos. Quando uma pessoa jurídica de direito público decide instituir uma empresa, ela o faz aproveitando o regime jurídico decorrente da personalidade jurídica de direito privado, própria das empresas. Sobre este regime jurídico básico e comum incidirão normas próprias, impertinentes às empresas do setor privado, que darão identidade às empresas estatais ${ }^{54}$.

\section{A Emenda Constitucional $\mathrm{n}^{\mathrm{o}} 19 / 98$ ratificou o interesse do} constituinte em enaltecer a equidade no que tange as empresas estatais e as sociedades privadas. De modo que seja evidente a homogeneidade entre o regime jurídico de Direito Privado e o regime aplicado às Estatais, no sentido de abrir caminho para que concorram de forma isonômica, não serem a elas atribuído trato distinto, conforme prevê o artigo 173, parágrafo $1^{\mathrm{o}}$, incisos II, III e parágrafo $2^{\mathrm{o}}$ da Constituição Federal ${ }^{55}$.

Neste sentido, as transformações do Direito Administrativo ao longo do tempo, como também a influência de Constituições em épocas distintas, acarretou na relativização dos termos que eram ponto chave na distinção da função precípua de cada empresa pública ou sociedade de economia mista.

\footnotetext{
${ }^{54}$ PINTO, Henrique Motta. Empresas estatais: modelo jurídico em crise? São Paulo, 2010. Dissertação de Mestrado. Orientador: Carlos Ari Sundfeld. Pontifícia Universidade Católica de São Paulo. 2010b.

${ }^{55}$ Art. 173. Ressalvados os casos previstos nesta Constituição, a exploração direta de atividade econômica pelo Estado só será permitida quando necessária aos imperativos da segurança nacional ou a relevante interesse coletivo, conforme definidos em lei. $\S 1^{\circ} \mathrm{A}$ lei estabelecerá o estatuto jurídico da empresa pública, da sociedade de economia mista e de suas subsidiárias que explorem atividade econômica de produção ou comercialização de bens ou de prestação de serviços, dispondo sobre: (Redação dada pela Emenda Constitucional no 19 , de 1998); II - a sujeição ao regime jurídico próprio das empresas privadas, inclusive quanto aos direitos e obrigações civis, comerciais, trabalhistas e tributários; (Incluído pela Emenda Constitucional no 19, de 1998) III licitação e contratação de obras, serviços, compras e alienações, observados os princípios da administração pública; (Incluído pela Emenda Constitucional no 19 , de 1998) § $2^{\circ}$ - As empresas públicas e as sociedades de economia mista não poderão gozar de privilégios fiscais não extensivos às do setor privado.
} 
Sundfeld e Pagani de Souza comentam a existência desta crise na distinção acima mencionada:

\begin{abstract}
Verifica-se, por um lado, que a própria distinção 'serviços públicos versus atividades econômicas' mostra sinais de crise, vez que a sua maior utilidade residia (ao menos supostamente) em permitir ao intérprete identificar, diante de um caso concreto, qual o regime jurídico aplicável à situação: em se tratando de atividade econômica em sentido estrito (assim qualificada pelo Direito), o caso se submeteria ao regime de direito privado; em se tratando de serviço público (como tal qualificado pela ordem jurídica), ele se sujeitaria ao regime de serviço público. O problema é que a legislação brasileira vem dificultando esta tarefa atribuída ao interprete (...), vez que tem reconhecido, por exemplo, serviços públicos não subordinados ao regime publicístico, mas sim a um regime de direito privado. Cai por terra, assim, a utilidade maior daquela distinção clássica e, no que tange ao regime das estatais, ela também se torna de utilidade questionável ${ }^{56}$.
\end{abstract}

Tenha-se em mente que, em decorrência da dificuldade de identificação da norma que seria corretamente aplicável às empresas estatais, esta distinção ${ }^{57}$ entre atividades econômicas e prestação de serviços públicos vem deixando de ter significância no que tange à definição do modelo jurídico das empresas estatais. Poder-se-ia dizer que a crise no regime jurídico das mesmas advém de um uso reduzido de tal diferenciação no momento em que irá se definir qual a melhor norma a ser aplicável.

\footnotetext{
${ }^{56}$ SUNDFELD, Carlos Ari; SOUZA, Rodrigo Pagani de. Licitação nas Estatais: Levando a Natureza Empresarial a Sério. In: Revista de Direito Administrativo. $\mathrm{n}^{\circ}$ 245. Rio de Janeiro, Atlas e FGV, 2007. maio-agosto 2007; p. 22. In: PINTO, 2010b, p. 34.

57 Henrique Motta Pinto, em sua dissertação de mestrado (PINTO, 2010b, p. 34.), trouxe importante crítica aduzida por Floriano de Azevedo Marques no que tange à distinção mencionada, no sentido de que a competição com o mercado privado pode ocorrer envolvendo empresas estatais que prestem serviços públicos, não somente aquelas que exploram atividade econômica. $\mathrm{O}$ autor afirma: "Hodiernamente, portanto, saber se a empresa estatal explora serviço público ou atividade econômica em sentido estrito parece ser irrelevante. Há empresas estatais que têm por objeto o desempenho de atividades industriais, comerciais, de serviços que hão de ser ofertadas à coletividade a título oneroso (ou seja, atividades econômicas em sentido amplo). Outras estatais têm por objetivo exercer função pública (o que enseja polêmicas sobre a adequação ou não do cometimento de poder extroverso inerente à função pública a entes submetidos ao regime privado, mesmo que sob controle estatal). Quanto a estas últimas, parece-me irrefutável a aplicação do regime de direito público como se faz para os entes da Administração centralizada". MARQUES NETO, Floriano de Azevedo. As contratações estratégicas das estatais que competem no mercado. Rio de Janeiro: Lumen Juris, 2006 In: OSORIO, Fabio Medina; SOUTO, VILLELA, Marcos Juruena (Coord.). Direito Administrativo - Estudos em Homenagem a Diogo de Figueiredo Moreira Neto. Rio de Janeiro: Lumen Juris, 2006. p. 581-582.
} 


\title{
2.1. O regime híbrido das empresas estatais
}

Conforme se nota, o constituinte buscou aproximar as estatais ao regime privado, em razão de sua conotação empresarial, pois as pessoas jurídicas de direito público possuem limitações que freiam a competitividade e impedem uma atuação eficiente que acompanhe o mercado privado.

No entanto, não é adequado que o operador do direito tenha em vista aplicar somente o Direito Privado sobre as empresas estatais, visto que é certa a existência de um regime híbrido, conforme denota Aragão:

\begin{abstract}
É exatamente este hibridismo que caracteriza as empresas do Estado: a adoção de um regime jurídico essencialmente privado, mas com inúmeras derrogações de direito público, a maior parte delas, inclusive de sede constitucional. Quando elas exercerem atividades econômicas que não sejam de titularidade do Estado (serviços e monopólios públicos), mas sim da iniciativa privada, com base no art. 173, além da personalidade jurídica de direito privado inerente à sua forma empresarial, não poderão ter vantagens distintas das outorgadas às empresas privadas, com o que estariam atuando em concorrência desleal com elas ${ }^{58}$.
\end{abstract}

O new public management ${ }^{59}$, como Alexandre Aragão menciona em sua obra, caracteriza a nova corrente que afirma a existência de uma fuga do Direito Administrativo para o direito privado por meio de medidas, tais como contratos de gestão, remunerações decorrentes de prêmios.

Note-se que as fronteiras entre direito público e direito privado não devem ser estagnadas, e isto serve como estímulo à Administração Pública para que exerça suas finalidades da forma mais eficiente possível.

Inobstante a isto, é necessário dizer que os princípios da Administração Pública devam ser mitigados em sua aplicação pelas empresas estatais. Isto ocorre, porque estas empresas também se submetem ao regime privado. Então, conforme Zambão afirma em seu artigo, existe um questionamento acerca da isonomia proposta pelo constituinte, se isto ocorreu apenas para obstar que os privilégios concedidos à Fazenda Pública

\footnotetext{
${ }^{58}$ ARAGÃO, Alexandre dos Santos de. Curso de Direito Administrativo. Rio de Janeiro: Forense, 2012. p. 122-123.

${ }^{59}$ ARAGÃO, 2017, p. 52.
} 
fossem concedidos as empresas do setor privado. Como resposta, Zambão afirma que:

De todo modo, pensamos ser mais adequado o entendimento que confere à paridade de regimes um sentido mais amplo, vedando exceções que beneficiem ou prejudiquem as estatais. A paridade de regimes, no presente contexto, deve ser considerada como uma via de mão dupla, impedindo que interpretações ampliativas do regime de direito público inviabilizem a atuação concorrencial da entidade. ${ }^{60}$.

Acerca do tratamento privilegiado comentado acima, o Supremo Tribunal Federal, por meio do RE $\mathrm{n}^{\mathrm{o}} 172.816 / \mathrm{RJ}^{61}$, expressou seu entendimento no que tange às empresas estatais que exploram atividade econômica:

O artigo $173 \S 1$ da Constituição Federal tem por objetivo assegurar a livre concorrência, de modo que as entidades públicas que exercem ou venham a exercer atividade econômica não se beneficiem de tratamento privilegiado em relação a entidades privadas que se dediquem a atividade econômica na mesma área ou em área semelhante ${ }^{62}$.

Neste mesmo RE, o Supremo Tribunal Federal expressou o seguinte:

A norma do art. $173, \S 1 .^{\circ}$, da Constituição aplica-se às entidades públicas que exercem atividade econômica em regime de concorrência, não tendo aplicação às sociedades de economia mista ou empresas públicas que, embora exercendo atividade econômica, gozam de exclusividade. $\mathrm{O}$ dispositivo constitucional não alcança, com maior razão, sociedade de economia mista federal que explora serviço público, reservado à União ${ }^{63}$.

Desta feita, definiu por meio de sua decisão que o artigo 173 do dispositivo constitucional não seria aplicável às empresas estatais que exercessem as atividades econômicas de forma exclusiva.

Deve-se ter em mente que a isonomia dos regimes, quando levada a sério, viabiliza uma concorrência leal entre o mercado privado e as estatais propriamente ditas. Por isso, a natureza empresarial das estatais deve ser levada a sério no momento de aplicação dos princípios constitucionais.

\footnotetext{
${ }^{60}$ SILVA, p. 241 In: ARAGÃO, 2015, p. 302.

${ }^{61}$ STF, RE no 172.816/RJ, Plenário, Rel. Ministro Paulo Brossard, Julgado em: 09 fev. 1994.

${ }^{62}$ Ibid.

SILVA, p. 241 In: ARAGÃO, 2015, p. 302.

${ }^{63}$ ARAGÃO, 2017, p. 52.
} 
Souto já afirmava que as entidades da Administração Pública indireta e sua diferenciação é essencial para a regular execução de suas atividades, cada entidade possui seu propósito específico:

A Constituição prevê quatro tipos de entidades na Administração Indireta, a saber, as autarquias, as empresas públicas, as sociedades de economia mista e as fundações. O que se pretende sustentar é que cada uma delas tem uma vocação distinta, não existindo, pois, discricionariedade nessa escolha ${ }^{64}$.

Assim sendo, não cabe ao Supremo Tribunal Federal mudar esse propósito por meio da autarquização dessas estatais, como demonstra a guinada demonstrada no RE anteriormente citado. Neste sentido, Oliveira afirma:

No entanto, ainda que se possa questionar a decisão sob a ótica do princípio da eficiência, não nos parece ser possível extrair da Constituição uma vedação da utilização de uma pessoa jurídica de direito público para o exercício de atividade econômica monopolizada ${ }^{65}$.

É evidente que deva existir ponderação dos princípios da Administração Pública a serem aplicados às estatais, tendo em vista que a aplicação dos mesmos não poderá ser um fator prejudicial para a competição que irá exercer frente as empresas do mercado privado, Filho segue este entendimento e explicita:

Ora, a eliminação dos benefícios e vantagens deve ser acompanhada da exclusão concomitante de encargos e ônus peculiares ao direito público, mas apenas na medida em que tal possa comprometer a atuação da entidade administrativa no mercado. Esse comprometimento caracteriza-se pela ofensa à isonomia em face dos agentes privados, em vista da eliminação da competitividade da entidade administrativa no âmbito do mercado. Não se aplicará o regime de direito público quando produzir encargos que tornem inviável a competição de empresa pública ou sociedade de economia mista com os agentes privados. O raciocínio aplica-se tanto ao aspecto de vantagens quanto ao de encargos constantes da disciplina publicística $^{66}$.

\footnotetext{
${ }^{64}$ SOUTO, Marcos Juruena Villela. Direito Administrativo Empresarial. Rio de Janeiro: Lumen Juris, 2006. p. 74.

${ }^{65}$ OLIVEIRA, Rafael Carvalho Rezende de. Administração Pública, Concessões e Terceiro Setor. Rio de Janeiro: Lumen Juris, 2011. p. 58.

${ }^{66}$ JUSTEN FILHO, Marçal. Comentários à lei de licitações e contratos administrativos. $17^{\mathrm{a}}$ ed. São Paulo: Revista dos Tribunais, 2016. p. 29.
} 
Desta feita, seguindo Aragão em sua fala, o correto seria afirmar que o regime das empresas estatais é híbrido:

\begin{abstract}
Sob essa perspectiva, o mais correto em relação ao regime jurídico das empresas estatais é afirmar que não é propriamente nem de Direito Privado, nem de Direito Público, tampouco de direito privado com derrogações de direito público: trata-se de outro regime jurídico, híbrido e atípico, decorrente da junção de elementos de ambos, elementos estes que, depois de colocados no mesmo ambiente, se modificam recíproca e intrinsecamente, de modo que, nem o elemento de direito privado o será como se estivesse sendo aplicado a um particular qualquer, nem os elementos de direito público que continuarem sendo aplicáveis às estatais o serão como incidem sobre o geral dos organismos públicos ${ }^{67}$.
\end{abstract}

Os elementos de direito privado e de direito público irão influenciar no regime da empresa estatal na medida em que exerce suas atividades. Se a empresa for competitiva, possuir maior influência do capital privado, ela irá tender para o direito privado, já se for o oposto, prestar serviços públicos, por exemplo, possuirá maior intromissão do direito público.

\title{
2.2. Espécies de atividades econômicas (lato sensu): serviços públicos, monopólios públicos, serviços públicos sociais e atividades econômicas (stricto sensu) do art. 173 da Constituição Federal
}

A dicotomia, a qual envolve a prestação de serviços públicos e exploração de atividades econômicas, podem ocorrer em regime tanto concorrencial, quanto monopolizado. Esta bifurcação é, de certa forma, defendida por Celso Antônio Bandeira de Mello ${ }^{68}$ e relativizada na obra Eros Roberto Grau, o mesmo ${ }^{69}$ explica que a atividade econômica seria o gênero, que envolveria como um todo a prestação de serviços públicos.

\footnotetext{
${ }^{67}$ ARAGÃO, 2017, p. 163.

${ }^{68}$ MELLO, Celso Antônio Bandeira de. Prestação de serviços públicos e administração indireta. $2^{\mathrm{a}}$ ed. São Paulo: Revista dos Tribunais, 1979.

69 "Na busca da determinação de tais sentidos, cuidemos de considerar conjuntamente as expressões atividade econômica e serviço público, ignorando, temporariamente, os usos que da primeira fazem o Decreto-lei 200/67 e a Constituição. A primeira indagação que então nos colocamos há de ser a seguinte: ocorre, de fato, oposição entre as noções de atividade econômica e de serviço público? Parece-me que não. Pelo contrário, entendo haver plena integração entre tais
} 
Tenha-se presente que o ato de explorar atividade econômica encontrava-se, inicialmente, vedada pela Constituição. No entanto, existem exceções, que são a prestação de serviço público, os monopólios públicos, as atividades do artigo 173 da Constituição, assim como os serviços públicos sociais.

As atividades sob publicatio ${ }^{70}$ exercidas pelas empresas estatais podem ser exercidas pelos particulares sob delegação, já as atividades concomitantes poder ser exercidas pelos particulares por meio de direito próprio.

É importante destacar que as empresas estatais que exercem atividades concomitantes precisam justificar previamente a finalidade pública para a qual destina suas atividades. Aragão afirma que além dos serviços públicos e atividades econômicas, existe o grupo do monopólio público $^{71}$ que será detalhado adiante. Ortiz explicita que independente do

noções, visto que atividade econômica é gênero no qual se inclui a prestação de serviços públicos.”.

${ }^{70}$ Alexandre dos Santos de Aragão diferencia as atividades econômicas prestadas pelas empresas estatais em dois grupos, o primeiro seriam as atividades exercidas sob publicatio, que se subdividem em serviços públicos e monopólios públicos, e o segundo grupo seria o de estatais que exercem atividades concomitantes, que seriam as atividades descritas no artigo 173 da Constituição da república Federativa do Brasil e os serviços públicos sociais. O referido autor esclarece em sua obra acerca das definições de serviços públicos sociais e as atividades do artigo 173 da Constituição: "Essa segunda exceção (exercício direto estatal em concomitância com a iniciativa privada) comporta duas subespécies: • os serviços públicos sociais, atividades ligadas à dignidade da pessoa humana que o Constituinte não só admite como determina que o Estado preste, às vezes gratuitamente, como a saúde (art. 199, CF) e a educação (art. 209, CF), outras vezes podendo cobrar por elas, como as atividades culturais e de lazer (arts. $6 .^{\circ}$ e 227, CF - ex.: museus e teatros públicos).11 A obrigação do Estado prestar essas atividades não faz com que os particulares, independentemente de qualquer delegação do Estado, também não as possam prestar; $12 \mathrm{e} \cdot$ as atividades econômicas da iniciativa privada em relação às quais o Estado seja, juntamente com a iniciativa privada, legislativamente autorizado a atuar por razões de relevante interesse coletivo ou de segurança nacional, guardando uma paridade de tratamento jurídico em relação aos seus concorrentes privados, titulares originariamente exclusivos daquelas atividades (art. 173, CF). Como exemplos poderíamos citar os bancos públicos e a distribuição de combustíveis explorada pela BR Distribuidora S.A.”.

ARAGÃO, 2017, p. 55-56.

${ }^{71}$ Alexandre dos Santos de Aragão indica a definição taxativa de monopólio público tal como segue: "l.a pesquisa, a lavra, o enriquecimento, o reprocessamento, a industrialização e o comércio de minérios e minerais nucleares e seus derivados, com exceção dos radioisótopos, nos termos dos arts. 21, XXIII, e 177, V, CF; 2. a pesquisa e a lavra de recursos minerais e o aproveitamento dos potenciais hidráulicos (art. 176, CF); e 3. a pesquisa e a lavra das jazidas de petróleo e gás natural e outros hidrocarbonetos fluidos, o refino de petróleo, a importação e exportação de hidrocarbonetos e dos seus derivados básicos, o transporte marítimo do petróleo nacional e seus derivados, bem como o transporte por duto de petróleo, seus derivados e gás natural, sejam eles de origem nacional ou não (art. 177, I a IV)". 
que exerça, a empresa estatal possuirá o intuito de cumprir sua finalidade pública:

Tanto nos serviços públicos como nas atividades econômicas o Estado busca a realização de finalidades públicas, que, todavia, são de espécies muito diferentes: na gestão econômica não há uma finalidade de serviço ao público, isto é, aos cidadãos individualmente considerados, mas uma finalidade de ordenação econômica, de conformação social, de serviço nacional, isto é, de promoção econômico-social da nação considerada em seu conjunto ${ }^{72}$.

Neste sentido, Aragão diferencia o monopólio público e serviço público na medida em que afirma que o serviço público está regulado pelo artigo 175 da Constituição Federal, neste contexto, é possível afirmar que existe a possibilidade do legislador infraconstitucional legislar sobre o tema desde que atenda ao Princípio da Proporcionalidade. Já o monopólio público necessita de uma previsão expressa e taxativa na Constituição.

Filho explica a distinção acima mencionada da seguinte forma:

Tal como dito, então, esse cenário conduziu a doutrina a agrupar as entidades da Administração Indireta, dotadas de personalidade jurídica de direito privado, em dois grandes grupos. A partir do exame da natureza de suas atribuições, costumase distinguir as entidades estatais ou como prestadoras de serviços públicos ou como exploradoras de atividade econômica. A distinção não é bizantina nem atende a reclamos de ordem puramente teórica. Ao contrário, reflete a submissão a regimes jurídicos distintos e permite identificar, de modo imediato, o conjunto de princípios e regras aplicáveis à atuação de cada entidade ${ }^{73}$.

O Supremo Tribunal Federal, no RE $172.816^{74}$ caracteriza-se por compreender que o artigo 173 da Constituição Federal não se aplica às empresas estatais que prestam serviço público de forma exclusiva, seria a elas aplicado, ao invés daquele, o artigo $175^{75}$ da mesma, que se caracterizaria como um regime mais próximo do Direito Público.

ARAGÃO, 2017, p. 52.

72 ORTIZ, Gaspar Ariño. Principios de derecho público económico. Granada: Comares e Fundación de Estudios de Regulación, 1999. p. 494 Apud ARAGÃO, Alexandre dos Santos de. Empresas Estatais. Rio de Janeiro: Forense. VitalBook file, 2017. p. 52-53.

${ }^{73}$ JUSTEN FILHO, Marçal. O Regime Jurídico das Empresas Estatais e Distinção entre "Serviço Público" e "Atividade Econômica". In: Revista de Direito do Estado. v. 1, 2006. p. 124.

${ }^{74}$ STF, RE no 172.816/RJ, Plenário, Rel. Ministro Paulo Brossard, Julgado em: 09 fev. 1994.

${ }^{75}$ Art. 175. Incumbe ao Poder Público, na forma da lei, diretamente ou sob regime de concessão ou permissão, sempre através de licitação, a prestação de serviços públicos. Parágrafo único. A lei disporá sobre: I - o regime das empresas concessionárias e permissionárias de serviços públicos, o 
É importante ressaltar que as atividades descritas no artigo 173 da Constituição Federal devem ser equiparadas ao regime privado, a fim de que a concorrência com o mercado privado seja executada de maneira leal e em situação de paridade.

A tendência de aproximação das empresas prestadoras de serviço público ao regime público é caracterizada pela grande concordância exprimida pelo Supremo Tribunal Federal, que, assim como a doutrina visualiza a distinção entre esses dois grandes grupos, tal como segue:

(...) 2. As sociedades de economia mista e as empresas públicas que explorem atividade econômica em sentido estrito estão sujeitas, nos termos do disposto no $\S 1^{\circ}$ do artigo 173 da Constituição do Brasil, ao regime jurídico próprio das empresas privadas. 3. Distinção entre empresas estatais que prestam serviço público e empresas estatais que empreendem atividade econômica em sentido estrito 4. $\mathrm{O} \S 1^{\circ}$ do artigo 173 da Constituição do Brasil não se aplica às empresas públicas, sociedades de economia mista e entidades (estatais) que prestam serviço público. $(. . .)^{76}$.

Em oposição a isto, existe forte corrente doutrinária seguidora da tese de que o artigo 173 da Constituição Federal é aplicável a qualquer uma das estatais citadas, sejam elas prestadoras de serviço público ou exploradoras de atividade econômica. Em conformidade com esta tese, Souto afirma:

A distinção entre estatais exploradoras de atividades econômicas e prestadoras de serviço público, em face da Lei $\mathrm{n}^{\circ} 8.987 / 96$ - que prevê que as concessões de serviços públicos não são exclusivas -, bem como da $\mathrm{EC} \mathrm{n}^{\circ}$ 19/98 - que trata da função social da empresa pública e da economia mista (CF, art. 173, § $1^{\circ}$, I a V) , começa a cair em desuso. Afinal, as estatais prestadoras de serviço público agora se prestam à implementação de um regime de competibilidade que repudia monopólios públicos ou privados ${ }^{77}$.

Essa corrente afirma que não há como existir dessemelhanças, se a execução das atividades econômicas se der de forma concorrente com o mercado privado. Sundfeld segue tal corrente, visto que muitas empresas

\footnotetext{
caráter especial de seu contrato e de sua prorrogação, bem como as condições de caducidade, fiscalização e rescisão da concessão ou permissão; II - os direitos dos usuários; III - política tarifária; IV - a obrigação de manter serviço adequado.

${ }^{76}$ ADI n ${ }^{\circ}$ 1642/MG, Ministro Eros Grau, Julgado em: 03 abr. 2008.

${ }^{77}$ SOUTO, Marcos Juruena Villela. Direito Administrativo da Economia. Rio de Janeiro: Lumen Juris, 2003. p. 91.
} 
estatais que prestam serviços públicos atuam neste segmento de maneira concorrencial:

Ao longo da década de 90 do último século experimentamos uma disseminação do fenômeno dos serviços públicos prestados em regime de competição (vejam aí os exemplos dos regimes das telecomunicações, da energia elétrica e do setor de portos) e, ainda, a quebra do monopólio do Estado sobre o desempenho de determinadas atividades econômicas (vejam aí o os casos de algumas atividades petrolíferas e de alguns serviços bancários). Em síntese, experimentamos a introdução do regime jurídico de competição, seja nos chamados serviços públicos econômicos, seja nas chamadas atividades econômicas em sentido estrito exploradas pelo Estado. (...) Daí a situação que hoje vivenciamos, de introdução e mesmo acirramento da disputa por mercados entre empresas privadas e empresas estatais. Podemos citar alguns exemplos que ilustram esta assertiva (cada qual, evidentemente, com suas nuanças): o caso da Petróleo Brasileiro S.A (PETROBRAS) e suas concorrentes privadas; o caso de determinados bancos estatais e seus concorrentes privados; o caso das companhias estaduais e municipais de saneamento básico e suas concorrentes privadas (as famosas multinacionais do setor de saneamento); entre outros ${ }^{78}$.

Marques Neto que aquiesce com o entendimento acima explicitado, no sentido de que a classificação das empresas estatais deveria independer de qualquer diferenciação no que tange à natureza da atividade que a estatal desempenha, por isso afirma o seguinte:

\begin{abstract}
O que me parece relevante para se verificar o regime jurídico a balizar a atividade da empresa estatal será a atividade que exerce e se a mesma se desenvolve em ambiente de competição ou não. No contexto jurídico e econômico atual, podemos ter atividades econômicas (agora em sentido amplo, é dizer, atividades às quais se pode atribuir relevância econômica) consideradas serviços públicos prestadas em regime de exclusividade ou de competição. Bem como podemos ter atividades econômicas em sentido estrito (aquelas que não são tomadas pela ordem jurídica como serviço público) exploradas em regime de monopólio ou competição, neste último caso como o gênero das atividades econômicas. Hodiernamente, portanto, saber se a empresa estatal explora serviço público ou atividade econômica em sentido estrito parece ser irrelevante $(. . .)^{79}$.
\end{abstract}

Mister se faz ressaltar que a descrição dual dos regimes impactou a jurisprudência do Supremo Tribunal Federal como se verá em análise a ser realizada no capítulo 3 deste trabalho. No entanto, a opção pela personalidade de Direito Privado deveria ser concedida às empresas estatais, a fim de que concorram com o mercado privado.

\footnotetext{
${ }^{78}$ SUNDFELD; SOUZA, 2007, p. 14-15.

${ }^{79}$ MARQUES NETO, 2006, p. 581.
} 
Se forem elas prestadoras de serviços públicos, que haja nuances do Direito Público, como é o caso das empresas que atuam em regime de monopólio, como Zambão da Silva explicita:

(...) pensamos que o critério ideal para determinar o regime aplicável deveria ser a simples opção pela personalidade jurídica de direito privado, permitindo, se for o caso, apenas alguns temperamentos decorrentes da continuidade do serviço público, especialmente para aquelas estatais que exerçam as suas atividades fora de um cenário concorrencial ${ }^{80}$.

Não seria o objetivo de a pesquisa retratar o papel do Estado atuante na economia de forma indireta, que se diga, por meio da regulação, como é o caso das agências reguladoras. Aragão explica a diferenciação entre o estado atuante de forma direta e indiretamente na economia, sem possui relação, no entanto com a distinção doutrinária tradicional:

O Estado atua diretamente na economia quando, através de qualquer dos seus instrumentos organizacionais, inclusive da Administração Indireta, é o próprio agente econômico, e essa atuação terá natureza empresarial quando o fizer de maneira sistemática e perene. Tanto é assim que o art. $175 \mathrm{da} C F$, ao se referir à exploração indireta de serviços públicos, se refere apenas aos particulares que com o Poder Público celebram contratos de concessão, não às entidades da Administração Indireta que recebam essa incumbência (de prestar serviços públicos) diretamente da lei. Por outro lado, o Estado pode atuar indiretamente na economia, como regulador, através de entidade de direito público da sua Administração Indireta, como as agências reguladoras, que são autarquias ${ }^{81}$.

Em suma, o viés empresarial de atuação do Estado pode-se dar por meio das empresas estatais, como também por meio de entes da administração direta. O escopo deste trabalho possui como finalidade precípua analisar o Estado como agente econômico, seja por meio da administração direta ou indireta. Na sequência, será estudado o regime das empresas estatais, no que tange às características que mais influenciam na questão da autarquização das mesmas, tornando seu regime mais próximo do regime público.

\footnotetext{
${ }^{80}$ SILVA, p. 241 In: ARAGÃO, 2015, p. 302.

${ }^{81}$ ARAGÃO, 2017, p. 60.
} 


\subsection{Tendência autarquizante do Supremo Tribunal Federal e a problemática dos privilégios às empresas estatais prestadoras de serviço público}

A atuação empresarial do Estado por meio de suas empresas estatais, que possuem, por óbvio, personalidade de direito privado, trazem intrinsicamente a si a aplicação das normas direcionadas ao setor privado. Isto ocorre para o melhor cumprimento de seu objeto social, que envolve questões econômicas.

No entanto, ao longo do tempo, a Corte veio aplicando, a diversos julgados que serão explicitados posteriormente, limitações à atuação das empresas estatais. Isto vem ocorrendo por meio da imposição de obrigatoriedade de submeter-se ao controle do tribunal de contas, licitar, realizar concursos públicos, entre outras atividades que são inerentes à Administração Pública.

O Supremo Tribunal Federal busca, e isto se depreende a partir de sua jurisprudência, conceder proteção integral, por meio da garantia de aplicação de privilégios, que são provenientes do Estado, às empresas estatais que prestam serviço público.

Cabe dizer que ao conceder privilégios, o Supremo Tribunal Federal, simultaneamente, limita a atuação das empresas estatais do ponto de vista empresarial, no que tange a concorrência com as empresas no setor privado. Visto que a partir do momento em que uma empresa estatal possui privilégios que o mercado privado não possui, a concorrência torna-se desleal, existiria uma intervenção exacerbada no domínio econômico.

Por isso é necessário destacar que o objeto deste tópico é dar notoriedade aos benefícios e privilégios que tais julgamentos impuseram às empresas estatais, existem as limitações que são inerentes à concessão de privilégios e serão comentadas, porém de forma alguma existe a pretensão de esgotá-las, não seria concernente ao escopo desta pesquisa. 
Após análise realizada por Alexandre dos Santos de Aragão, pode-se depreender do posicionamento do Supremo Tribunal Federal que seus julgamentos foram similares no que tangencia ao regime de execução, envolvendo, a título exemplificativo, a questão de penhora dos bens das estatais, assim como o regime tributário, quando se fala em concessão de imunidade e isenções.

Isto é, em sua jurisprudência a Corte julgou com base na diferenciação entre estatais prestadoras de serviço público e as que exploram atividades econômicas em sentido estrito. Por tal motivo, escolheu-se abranger neste trabalho especificamente os dois regimes a seguir analisados, pois as duas matérias podem ser analisadas sob o mesmo prisma.

\subsubsection{Implicações do artigo 150, parágrafo $3^{\circ}$ da Constituição Federal $^{82}$ no regime tributário}

Este tópico irá tratar do regime tributário que as empresas estatais possuem, com base no artigo 173 , parágrafo $1^{\circ}$, inciso II da Constituição Federal $^{83}$, o qual também o é das empresas privadas, sendo que seguindo o texto constitucional, os benefícios, sejam eles a imunidade tributária ou as isenções, poderão ser aplicados às estatais somente se puderem ser estendidos às empresas do mercado privado ${ }^{84}$.

\footnotetext{
${ }^{82}$ Art. 150. Sem prejuízo de outras garantias asseguradas ao contribuinte, é vedado à União, aos Estados, ao Distrito Federal e aos Municípios: $\S 3^{\circ}$ - As vedações do inciso VI, "a", e do parágrafo anterior não se aplicam ao patrimônio, à renda e aos serviços, relacionados com exploração de atividades econômicas regidas pelas normas aplicáveis a empreendimentos privados, ou em que haja contraprestação ou pagamento de preços ou tarifas pelo usuário, nem exonera o promitente comprador da obrigação de pagar imposto relativamente ao bem imóvel.

83 Art. 173. Ressalvados os casos previstos nesta Constituição, a exploração direta de atividade econômica pelo Estado só será permitida quando necessária aos imperativos da segurança nacional ou a relevante interesse coletivo, conforme definidos em lei. $\S 1^{\circ}$ A lei estabelecerá o estatuto jurídico da empresa pública, da sociedade de economia mista e de suas subsidiárias que explorem atividade econômica de produção ou comercialização de bens ou de prestação de serviços, dispondo sobre: II - a sujeição ao regime jurídico próprio das empresas privadas, inclusive quanto aos direitos e obrigações civis, comerciais, trabalhistas e tributários.

${ }^{84} \mathrm{O}$ parágrafo $2^{\circ}$ do artigo 173 da Constituição, segundo Carolina Barros Fidalgo: "veda a previsão de quaisquer privilégios fiscais em favor das sociedades estatais, que não sejam também extensíveis às empresas do setor privado".
} 
Objetivamente, este tópico irá abordar a interpretação, como Alexandre dos Santos de Aragão bem define, "contra constitutionem", adotada pelo Supremo Tribunal Federal em seus julgados sobre empresas estatais, no que toca a concessão de imunidade recíproca ${ }^{85}$ e isenções ${ }^{86}$.

A Corte limitou a concessão de privilégios, que seriam essas imunidades e isenções às estatais exploradoras de atividades econômicas e às que prestam serviço público na modalidade concorrente com o mercado privado. Um dos casos emblemáticos, em que se foi negada a concessão de imunidade tributária, foi o Agravo Regimental em Recurso Extraordinário 285.716 ${ }^{87}$, que envolveu a sociedade de economia mista Petrobrás:

\begin{abstract}
A imunidade tributária recíproca não se aplica à Petrobras, pois: 3.1. Trata-se de sociedade de economia mista destinada à exploração econômica em benefício de seus acionistas, pessoas de direito público e privado, e a salvaguarda não se presta a proteger aumento patrimonial dissociado de interesse público primário; 3.2. A Petrobras visa a distribuição de lucros, e, portanto, tem capacidade contributiva para participar do apoio econômico aos entes federados; 3.3. A tributação de atividade econômica lucrativa não implica risco ao pacto federativo ${ }^{88}$.
\end{abstract}

FIDALGO, Carolina Barros. O Estado empresário: regime jurídico das tradicionais e novas formas de atuação empresarial do estado na economia brasileira. Rio de Janeiro. 2012. 370 f. p. 166. Dissertação de Mestrado em Direito. Faculdade de Direito, Universidade do Estado do Rio de Janeiro, 2012. p. 205.

${ }^{85}$ E importante destacar que o objetivo deste tópico não é exaurir todos os tipos de imunidades tributárias previstas constitucionalmente, mas tão somente a imunidade recíproca, por ser ela a que se relaciona ao tema de estudo. A fim de esclarecer o que seriam essas imunidades, a autora Carolina Fidalgo faz referência em sua dissertação de mestrado como "a primeira", se referindo as mesmas, e possuindo como base o Tratado do ilustre autor Ricardo Lobo Torres: "A primeira só pode ser prevista pela Constituição Federal e importa em exclusão total do poder de tributar do Estado, isto é, em incompetência absoluta para a aplicação de um tributo sobre determinada hipótese". Afirma ainda ser a imunidade recíproca seu interesse de pesquisa no tópico, ser esta referente ao inciso VI, do art. 150, da Constituição, que: "pró́be a instituição de impostos sobre o patrimônio, renda ou serviços de outros entes da Federação".

TORRES, Ricardo Lobo. Tratado de Direito Constitucional, Financeiro e tributário. v. III. Rio de Janeiro: Renovar, 2005. p. 491 In: FIDALGO, Carolina Barros. O Estado empresário: regime jurídico das tradicionais e novas formas de atuação empresarial do estado na economia brasileira. Rio de Janeiro. 2012. 370 f. p. 166. Dissertação de Mestrado em Direito - Faculdade de Direito, Universidade do Estado do Rio de Janeiro, 2012. p. 197.

${ }^{86}$ Novamente, a ilustre autora Carolina Barros Fidalgo, em sua dissertação de mestrado, definiu o que seriam as isenções: "As isenções, por sua vez, consistem em autolimitações ao poder fiscal ("o próprio poder tributante limita o exercício de sua competência”), podendo ser previstas por lei ordinária, desde que atendidos os princípios da proporcionalidade e isonomia. O seu efeito é a derrogação da incidência de determinado tributo a uma hipótese específica".

TORRES, 2005, p. 491. In: FIDALGO, 2012, p. 197.

${ }^{87}$ STF, RE no 285.716 AgRg, $2^{\text {a }}$ Turma, Rel. Ministro Joaquim Barbosa, Julgado em: 02 mar. 2010.

${ }^{88}$ ARAGÃO, 2017, p. 280-281. 
A justificativa que se utilizou foi justamente a de que ela explora atividade econômica, e um dos parâmetros utilizados para não aplicar o regime de imunidade tributária recíproca, pelo Supremo Tribunal Federal, e elencado pelo ilustre Aragão:

Como se vê, de acordo com o STF, três pontos devem ser alternativamente considerados a fim de se verificar a não incidência da imunidade tributária: (i) se a tributação não incide sobre bens e serviços inerentes à satisfação dos objetivos públicos do ente federativo; (ii) se a tributação incide sobre atividades econômicas desenvolvidas com o objetivo de lucro, com o que em princípio as sociedades de economia mista, por terem necessariamente sócios privados, estariam afastadas da possibilidade de usufruírem das vantagens de ser Fazenda Pública, salvo se forem sociedades de economia mista meramente nominais; e (iii) se a tributação incide sobre atividade desenvolvida em regime de concorrência ${ }^{89}$.

Baseando-se no texto constitucional ${ }^{90}$, não teriam direito à imunidade recíproca as que explorem atividades econômicas ou que cobrem uma contraprestação e, diferentemente das empresas estatais, o parágrafo $2^{\circ}$ deste artigo 150, da Constituição afirma expressamente que as autarquias podem desfrutar deste privilégio.

Por estar expresso no texto constitucional que as empresas estatais que cobram contraprestação de seus usuários não teriam direito à imunidade, Fidalgo relata em sua dissertação que o absurdo em comum notado nos julgados da Empresa de Correios e Telégrafos, Infraero (que será detalhado adiante) e $\operatorname{CODESP}^{91}$ seria o de que essas três estatais cobram a referida contraprestação, e mesmo assim obtiveram o benefício:

\footnotetext{
${ }^{89}$ ARAGÃO, 2017, p. 278.

${ }^{90}$ Artigo 150, parágrafo $3^{\circ}$, Constituição Federal.

BRASIL. Constituição da República Federativa do Brasil de 1988. Disponível em: <http://www.planalto.gov.br/ccivil_03/constituicao/constituicaocompilado.htm〉. Acesso em: 21 mai. 2017.

${ }^{91}$ No caso da CODESP, Recursos Extraordinários no 253.472, 265.749 (Julgado em: 27.05.2003), 318.185 (09.03.2004), 357.447 (01.03.2004) e 253.472 (25.08.2010) e nos Agravos de Instrumentos $\mathrm{n}^{\circ} 391.873(01.02 .2007)$ e 351.888 (01.02.2007), o município de Santos estava cobrando IPTU sobre imóveis utilizados pela Companhia Docas do Estado de São Paulo CODESP, que eram utilizados para a prestação de serviço público portuário. Em seu desfecho, foi concedida a imunidade tributária, pois, de acordo com a Relatora Ministra Ellen Gracie: "Os imóveis integrantes do acervo patrimonial do Porto de Santos são imunes à incidência do IPTU, pois integram o domínio da União e se encontram ocupados pela agravada apenas em caráter precário".
} 
O interessante (ou absurdo) de todos esses julgados é que apenas nesse RE $n^{\circ}$ 253.472 o STF veio a atentar para o disposto no parágrafo $3^{\circ}$ do artigo 150 , o que se fazia essencial, já que tanto a CODESP, quanto a ECT, quanto a INFRAERO, se enquadram, a toda evidencia, na exceção prevista nesse parágrafo. Ainda que seja discutível se elas submetem ou não ao regime de direito público, fato é que o referido dispositivo também excepciona do âmbito de incidência da imunidade tributária aquelas entidades que exploram atividades mediante "contraprestação ou pagamento de preços ou tarifas pelo usuário", o que ocorre nesses três casos ${ }^{92}$.

A crítica relevante constante da dissertação de Carolina Barros Fidalgo seria a de que o Supremo Tribunal Federal, no entanto, contrariando o disposto no parágrafo $3^{\circ}$ do artigo 150, da Carta Constitucional, estaria aplicando a imunidade recíproca prevista no inciso VI, 'a' do mesmo artigo às empresas estatais prestadoras de serviços públicos, sem discriminar se seriam esses prestados de forma concorrente ou exclusiva.

O Supremo Tribunal Federal concedeu a imunidade tributária recíproca, afastando a cobrança de ISS sobre os bens da Infraero por meio do Agravo Regimental em Recurso Extraordinário 363.41293.

\begin{abstract}
A Infraero, que é empresa pública, executa, como atividade-fim, em regime de monopólio, serviços de infraestrutura aeroportuária constitucionalmente outorgados à União Federal, qualificando-se, em razão de sua específica destinação institucional, como entidade delegatária dos serviços públicos a que se refere o art. 21, inciso XII, alínea "c", da Lei Fundamental, o que exclui essa empresa governamental, em matéria de impostos, por efeito da imunidade tributária recíproca (CF, art. 150, VI, "a"), do poder de tributar dos entes políticos em geral. Consequente inexigibilidade, por parte do Município tributante, do ISS referente às atividades executadas pela INFRAERO na prestação dos serviços públicos de infraestrutura aeroportuária e daquelas necessárias à realização dessa atividade-fim. $\mathrm{O}$ alto significado político-jurídico da imunidade tributária recíproca, que representa verdadeira garantia institucional de preservação do sistema federativo. Doutrina. Precedentes do STF. Inaplicabilidade, à Infraero, da regra inscrita no art. 150, § $3 .^{\circ}$, da Constituição. A submissão ao regime jurídico das empresas do setor privado, inclusive quanto aos direitos e obrigações tributárias, somente se justifica, como consectário natural do postulado da livre concorrência (CF, art. 170, IV), se e quando as empresas governamentais explorarem atividade econômica em sentido estrito, não se aplicando, por isso mesmo, a disciplina prevista no art. $173, \S 1 .^{\circ}$, da Constituição, às empresas
\end{abstract}

In: FIDALGO, Carolina Barros. O Estado empresário: regime jurídico das tradicionais e novas formas de atuação empresarial do estado na economia brasileira. Rio de Janeiro. 2012. 370 f. p. 166. Dissertação de Mestrado em Direito - Faculdade de Direito, Universidade do Estado do Rio de Janeiro, 2012. p. 199.

${ }^{92}$ FIDALGO, 2012, p. 199.

${ }^{93}$ STF, RE no 363.412 Agravo Regimental, $2^{\text {a }}$ Turma, Rel. Ministro Celso de Mello, Julgado em: 07 ago. 2007. 
públicas (caso da Infraero), às sociedades de economia mista e às suas subsidiárias que se qualifiquem como delegatárias de serviços públicos ${ }^{94}$.

Seguindo o entendimento que havia sido adotado em relação a $\mathrm{ECT}^{95}$, caso em que também foi concedida a imunidade tributária recíproca, pois ficou reconhecido que a empresa não utiliza as contraprestações para auferir lucro, mas reverte para custear o próprio serviço público prestado.

Carolina Barros Fidalgo, em concordância com José dos Santos Carvalho Filho e Diogo de Figueiredo Moreira Neto ${ }^{96}$ defendem que o legislador poderia criar isenções que fossem favoráveis às entidades que prestam os serviços públicos de forma exclusiva.

Neste sentido, o julgado ${ }^{97}$ mais recente, do presente ano, acerca da concessão de imunidade tributária recíproca à empresa estatal é o Agravo Regimental em Ação Cível Originária n ${ }^{\circ}$ 2730, em que a Corte afirma o seguinte:

A imunidade tributária recíproca pode ser estendida a empresas públicas ou sociedades de economia mista prestadoras de serviço público de cunho essencial e exclusivo. (...) Acerca da natureza do serviço público de saneamento básico, trata-se de compreensão iterativa do Supremo Tribunal Federal ser interesse comum dos entes federativos, vocacionado à formação de monopólio natural, com altos custos operacionais. (...) A empresa estatal presta serviço público de abastecimento de água e tratamento de esgoto, de forma exclusiva, por meio de convênios municipais. Constata-se que a participação privada no quadro societário é irrisória e não há intuito lucrativo. Não há risco ao equilíbrio concorrencial ou à livre iniciativa, pois o tratamento de água e esgoto consiste em regime de monopólio natural e não se comprovou concorrência com outras sociedades empresárias no mercado relevante.

\footnotetext{
${ }^{94}$ ARAGÃO, 2017. p. 280.

${ }^{95}$ Recursos Extraordinários $\mathrm{n}^{\circ} 407.099$ (Julgado em: 22.6.2004), 354.897 (17.8.2004), 398.630 (17.8.2004), 424.227 (24.8.2004), 364.202 (05.10.2004); e das Ações Cíveis Originárias no 811 (26.04.2007), 959 (17.3.2008), 1095 (17.3.2008), 765 (13.5.2009).

${ }^{96}$ MOREIRA NETO, Diogo de Figueiredo. Curso de Direito Administrativo. 14a ed. Rio de Janeiro: Editora Forense, 2006. p. 261

CARVALHO FILHO, José dos Santos. Manual de Direito Administrativo. $18^{\mathrm{a}}$ ed. Rio de Janeiro: Lumen Juris, 2008. p. 447 In: FIDALGO, Carolina Barros. O Estado empresário: regime jurídico das tradicionais e novas formas de atuação empresarial do estado na economia brasileira. Rio de Janeiro. 2012. 370 f. p. 166. Dissertação de Mestrado em Direito - Faculdade de Direito, Universidade do Estado do Rio de Janeiro, 2012. p. 206.

${ }^{97}$ STF, Agravo Regimental em Ação Cível Originária no 2730, Plenário. Rel. Ministro Edson Fachin, Julgado em: 07 mar. 2017.
} 
Em contrapartida, Regina Helena Costa ${ }^{98}$ discorda do entendimento acima citado, estando em consonância com a tese adotada pelo Ministro Luis Roberto Barroso, no Recurso Extraordinário da Sabesp nº $600.867^{99}$, pois acredita que a prestação de serviço público por meio da empresa estatal seria a forma descentralizada de poder do Estado. Então, seja ou não cobrada a contraprestação, aplica-se a imunidade ${ }^{100}$.

De toda forma e para que se conclua este tópico, a doutrina a que nos filiamos é a seguida por Alexandre dos Santos de Aragão, no sentido de que o artigo 150 , parágrafo $3^{\circ}$ do texto constitucional não permite que as empresas estatais prestadoras de serviço público, as quais cobrem contraprestação, recebam a prerrogativa de imunidade recíproca.

Adiantando o próximo tópico que irá analisar o regime de execução, o qual vem passando pela mesma já referida tendência autárquica, Motta Pinto esclarece que o aspecto empresarial e privado das empresas estatais vem sendo mitigado pela Corte:

\begin{abstract}
Quando uma estatal passa a deter um regime privilegiado de execução e tributação, sua personalidade de direito privado fica mitigada. Com a totalidade dos seus bens protegida da execução e com o seu patrimônio, a sua renda e os seus serviços resguardados da tributação por impostos, essas entidades estatais se igualam, nesses aspectos, às pessoas de direito público. A permanência de outros aspectos decorrentes da sua personalidade de direito privado, como o regime trabalhista comum (celetista) e a autonomia orçamentária diante da pessoa de direito público que a controla, quando existente, coloca as empresas estatais
\end{abstract}

\footnotetext{
98 "Se o serviço público for prestado diretamente pela pessoa política estará, indubitavelmente, imune à tributação por via de impostos. Ora, a mera delegação da execução desse serviço público, pela pessoa que é titular da competência para prestá-lo à coletividade, por meio de lei, a uma empresa por ela instituída - empresa pública delegatária do serviço, não pode, portanto, alterar o regime jurídico - inclusive tributário - que incide sobre a mesma presta".

COSTA, Regina Helena. Imunidades Tributárias: teoria e análise da jurisprudência do STF. São Paulo: Malheiros Editores, 2001. p. 144-145 In: ARAGÃO, Alexandre dos Santos de. Empresas Estatais. Rio de Janeiro: Forense. VitalBook file, 2017. p. 277.

${ }^{99} \mathrm{Na}$ sessão plenária de 06.08.2015, a Ministra Carmen Lúcia pediu vista dos autos - que se encontram em seu gabinete desde o dia 13.08.2015.

ARAGÃO, Alexandre dos Santos de. Empresas Estatais. Rio de Janeiro: Forense. VitalBook file, 2017. p. 280.

${ }^{100}$ A não ser que a empresa estatal tenha por finalidade a obtenção de lucro, seja destinada ao sócio particular minoritário ou ao Estado, ou que preste o serviço público na modalidade concorrência com o mercado privado.
} 
privilegiadas em algum ponto no meio do caminho entre as empresas estatais "genuínas" e as autarquias ${ }^{101}$.

A partir de agora iremos analisar o impacto desta mitigação referida acima, também no regime de execução das empresas estatais prestadoras de serviços públicos.

\subsubsection{As estatais prestadoras de serviços públicos e seu regime de execução}

Há que se dizer que as pessoas jurídicas detentoras de personalidade de direito público possuem a benesse de procedimento especial executório similar ao da Fazenda Pública, por essas pessoas de direito público serem consideradas extensão do próprio estado, como é o caso das autarquias e fundações públicas.

Por serem as empresas estatais pessoas jurídicas de direito privado, com base no Código Civil ${ }^{102}$, como também mencionado por Alexandre Santos de Aragão em seu livro ${ }^{103}$, autores como Marcos Juruena Villela Souto, Celso Rodrigues Ferreira Junior, Diógenes Gasparini, Maria Sylvia Zanella Di Pietro, entre outros ${ }^{104}$, defendem que os bens das empresas estatais são privados.

101 PINTO, Henrique Motta. A autarquização das Empresas Estatais na jurisprudência do Supremo Tribunal Federal: um obstáculo para as reformas na administração pública. v. 15. n. 57. São Paulo: Cadernos de Gestão Pública e Cidadania, 2010a. p. 11.

102 Código Civil, artigo 98.

BRASIL. Código Civil, Lei 10.406, de 10 de janeiro de 2002. Disponível em: <http://www.planalto.gov.br/ccivil_03/leis/2002/L10406compilada.htm>. Acesso em: 15 mai. 2017.

103 ARAGÃO, Alexandre dos Santos de. Empresas Estatais. Rio de Janeiro: Forense. VitalBook file, 2017. p. 314.

104 Alexandre dos Santos de Aragão menciona os autores a seguir como aqueles que defendem ser privados os bens pertencentes às empresas estatais.

VILLELA SOUTO, 2003, p. 109.

FERREIRA JUNIOR, Celso Rodrigues. Do Regime de Bens das Empresas Estatais: Alienação, Usucapião, Penhora e Falência. In: SOUTO, Marcos Juruena Villela (Coord.). Direito Administrativo Empresarial. Rio de Janeiro: Lumen Juris, 2006. p. 74.

ROLIM, Luis Antonio. A Administração Indireta, as Concessionárias e Permissionárias em Juízo. Características das autarquias, empresas públicas, sociedades de economia mista, fundações públicas e dos particulares em colaboração com o Estado. São Paulo: RT, 2004.

BORGES, Alice Gonzalez. Impenhorabilidade de Bens. Sociedade de Economia Mista Concessionária de Serviços Portuários. Bens afetados à Prestação de Serviço Público. Revista 
Em contraposição, existem autores ${ }^{105}$ que afirmam serem os bens das empresas estatais como bens públicos. Alexandre dos Santos de Aragão menciona em sua obra, acima referida, que um dos defensores desta corrente seria Hely Lopes Meirelles, o qual afirma que os bens seriam públicos:

Mas com destinação especial e sob administração privada da estatal para os fins previstos em seu estatuto. Ainda de acordo com o autor, quando da extinção da empresa estatal, esses bens são reincorporados à entidade pública que os integralizou ${ }^{106}$.

Motta Pinto esclarece, em sua dissertação, que a concessão de impenhorabilidade dos bens ${ }^{107}$ das empresas estatais que prestam serviço público é considerada um privilégio, pois as empresas do setor privado não desfrutam de tal benefício, segundo o autor:

Se o fundamento para a declaração da impenhorabilidade de bens usar um critério objetivo, com a análise da qualidade de certo bem como público, ou da afetação do bem à prestação de um serviço público, não se tratará de um privilégio, uma vez que a proteção será extensível a uma empresa privada prestadora de serviço público. Portanto, a impenhorabilidade de bens de uma empresa estatal de serviço

Eletrônica de Direito Administrativo - REDAE. n. 11, 2007. p. 2-13. Disponível em: <http://www.direitodoestado.com/revista/REDAE-11-AGOSTO-2007-

ALICE\%20GONZALEZ.pdf>. Acesso em: 13 fev. 2012.

FURTADO, Lucas Rocha. Curso de Direito Administrativo. Belo Horizonte: Fórum, 2007. p. 206207 ;

GASPARINI, Diógenes. Direito Administrativo. $11^{\mathrm{a}}$ ed. São Paulo: Saraiva, 2006. p. 435.

DI PIETRO, Maria Sylvia Zanella. Direito Administrativo. $22^{\mathrm{a}}$ ed. São Paulo: Atlas, 2008. p. 461. MENDONÇA, José Vicente Santos de. A Captura Democrática da Constituição Econômica. Uma proposta de releitura das atividades públicas de fomento, disciplina e intervenção direta na Economia à luz do pragmatismo e da razão pública, 2010. 485f. Tese (Doutorado em Direito) Faculdade de Direito, Universidade do Estado do Rio de Janeiro, Rio de Janeiro, 2010. p. 233.

ARAÚJO, Edmir Netto de. Curso de Direito Administrativo. São Paulo: Saraiva, 2010. p. 241. ARAGÃO, Alexandre dos Santos de. Curso de Direito Administrativo. $2^{\mathrm{a}}$ ed. rev. atual. e ampl. Rio de Janeiro: Forense, 2013. p. 124. In: ARAGÃO, Alexandre dos Santos de. Empresas Estatais. Rio de Janeiro: Forense. VitalBook file, 2017. p. 315.

${ }^{105}$ MUKAI, Toshio. O Direito Administrativo e os Regimes Jurídicos das Empresas Estatais. 2. ed. Belo Horizonte: Fórum, 2004. p. 227, 269.

ATALIBA, Geraldo. Sabesp. Serviço público. Delegação a empresa estatal, Imunidade a impostos. Regime de taxas In: Revista de Direito Público - RDP. v. 92. p. 89, 1989 In: ARAGÃO, Alexandre dos Santos de. Empresas Estatais. Rio de Janeiro: Forense. VitalBook file, 2017. p. 315.

106 MEIRELLES, Hely Lopes. Direito Administrativo Brasileiro. 32 a ed. São Paulo: Malheiros Editores, 2006. p. 367.

${ }^{107} \mathrm{CF} / 88$, art. 100, caput e parágrafos $1^{\circ}$ a 16 . NCPC, arts. 910, CAPUT e parágrafo $1^{\circ}, 535$, parágrafo $3^{\circ}$, inciso I. 
público significará um privilegio quando for inacessível as empresas do setor privado prestadoras de serviço público ${ }^{108}$.

A concessão em razão de ser, contraposta por alguns doutrinadores $^{109}$, a empresa estatal prestadora de serviço público, exatamente como acima descrito por Henrique Motta Pinto, seria segundo ele a utilização de um critério "subjetivo".

Tal critério passou a ser utilizado e afirmado pelo Supremo Tribunal Federal, pois segundo ele, a empresa estatal que presta serviço público deveria possuir as mesmas prerrogativas da Fazenda Pública. Este posicionamento refletiu no caso pioneiro da Companhia Docas do Rio de Janeiro, da ECT em 2000, entre 2008 e 2009 nos julgados da ELETRONORTE, EMDUR-Porto Velho, CARHP-AL, CASAL-AL, EBDA-BA. No entanto, foi parcialmente seguido Metrô-SP ${ }^{110}$ no ano de 2005 e não aplicaram os benefícios nos casos SANED-Diadema, CEHOPSE e CASAL-AL.

Dentre os julgados mencionados, os que serão estudados a fundo serão os casos de maior relevância para o objeto da presente pesquisa, que é o julgado da Companhia Docas do Rio de Janeiro e da Empresa de Correios e Telégrafos. Cabe ressaltar que não atende ao escopo deste trabalho a análise profunda de todos os casos julgados pelo Supremo Tribunal Federal no que concerne às empresas estatais e a execução de seus bens, visto que

\footnotetext{
108 PINTO, 2010b, p. 113.

${ }^{109}$ Em contraposição a isto, existem autores, como expresso na obra de Alexandre dos Santos de Aragão, que defendem a impenhorabilidade de bens das empresas estatais, não pela razão de ser, como Henrique Motta Pinto afirma, mas por estarem atrelados diretamente à prestação de serviços públicos e Alexandre dos Santos de Aragão menciona como exemplo o caso das concessionárias, em que os bens são afetados por serem inerentes a prestação do serviço público. Os autores que reafirmam esta tese são Luis Antonio Rolim, Alice Gonzalez Borges, Edmir Netto de Araújo, Maria Sylvia Zanella Di Pietro, José Vicente Santos de Mendonça. (In: ARAGÂO, 2017, p. 316). 110 No caso do Metrô-SP, no RE 472.003/SP (Recorrente: Metrô-SP, recorrida: Catenco Engenharia S/A, homologada pelo Ministro Relator Carlos Britto em 7 de março de 2007), a Corte, segundo Henrique Motta Pinto: "suspendeu a penhora, afirmando o privilégio por se tratar de uma estatal de serviços públicos, mas não determinou que a execução ocorresse por meio de precatórios". Esta coletânea de jurisprudência trazida por Henrique Motta Pinto em sua dissertação de mestrado, em que identificou se a tendência autarquizante estava ou não sendo seguida nos julgados expostos acima.
}

PINTO, 2010b, p. 114. 
os casos a serem estudados exemplificam a tendência autarquizante da Corte.

O Recurso Extraordinário 172.816 111 , Alexandre dos Santos de Aragão o caracteriza como "leading case", e explicita que o julgado teve seu alicerce na questão da possibilidade de desapropriação de bem da Companhia Docas do Rio de Janeiro, sociedade de economia mista federal, a qual presta serviço público. A Corte decidiu com base na diferenciação entre prestação de serviço público de maneira concorrencial ou exclusiva, como no caso se considerou exclusiva, decidiu-se que o parágrafo $1^{\circ}$ do artigo 173 da Constituição Federal não se aplicaria a esta sociedade de economia mista.

No mesmo sentido, em 2000, Henrique Motta Pinto detalha o julgamento dos cinco ${ }^{112}$ recursos que envolveram a Empresa de Correios e Telégrafos, empresa pública federal, que envolviam penhoras de bens com a finalidade de pagamento de dívidas decorrentes de lides trabalhistas.

Cabe destacar que o artigo 12 do Decreto-lei 509 de $1969^{113}$ havia concedido à ECT proteção em relação aos seus bens, e a Corte julgou este caso no mesmo sentido da Companhia das Docas, afastando a penhorabilidade dos seus bens por ser ela considerada estatal que presta serviços públicos de forma exclusiva, confirmando a proteção que é inerente ao Estado.

\footnotetext{
${ }^{111}$ STF, RE no 172.816/RJ, Plenário, Rel. Ministro Paulo Brossard, Julgado em: 09 fev. 1994.

${ }^{112}$ RE 220.906/DF, Plenário, Rel. Ministro Maurício Corrêa, Julgado em: 16 de novembro de 2000.

RE 230.072/RS Plenário, Rel. Ministro Ilmar Galvão, Redator para o Acórdão Ministro Maurício Corrêa, Julgado em: 16 nov. 2000.

RE 230.051/SP, Plenário, Rel. Ministro Ilmar Galvão, Redator para o Acórdão Ministro Maurício Corrêa, Julgado em: 6 nov. 2000.

RE 225.011/MG, Plenário, Rel. Ministro Marco Aurélio, Redator para Acórdão Ministro Maurício Corrêa Julgado em: 16 nov. 2000.

RE 229.696/PE, Plenário, Rel. Ministro Ilmar Galvão, Redator para Acórdão Ministro Maurício Corrêa, Julgado em: 16 nov. 2000.

113 "A ECT gozará de isenção de direitos de importação de materiais e equipamentos destinados aos seus serviços, dos privilégios concedidos à Fazenda Pública, quer em relação a imunidade tributária, direta ou indireta, impenhorabilidade de seus bens, rendas e serviços, quer no concernente a foro, prazos e custas processuais".
} 
No próximo capítulo desta monografia serão detalhados os julgados acima retratados, além de destacar o voto contra e vencido do Ministro Sepúlveda Pertence neste julgado da Empresa de Correios e Telégrafos, nos Recursos Extraordinários 220.906 e 229.969, por meio do qual declarou sua oposição a esta tendência autarquizante do Supremo Tribunal Federal. 


\section{CAPÍTULO 3 - A CRISE DE IDENTIDADE DAS EMPRESAS ESTATAIS}

Não se pode olvidar a nítida existência de uma crise no modelo jurídico das Empresas Estatais, acerca da identificação de seu regime jurídico. Será analisado a seguir que a jurisprudência do Supremo Tribunal Federal, ao 'autarquizar' as Empresas Estatais, passou a tornar deficiente a prestação do serviço público, pois que ao estado näo seria dada a oportunidade de selecionar o melhor meio para executar a prestação.

Os danos decorrentes dos julgados do Supremo Tribunal Federal, de fato, não se relacionam às Empresas Estatais exploradoras de atividade econômica, mas apenas se liga às Empresas Estatais prestadoras de serviços públicos e será a partir disso a identificação da crise do modelo jurídico das empresas estatais.

Esta tendência autarquizante do Supremo Tribunal Federal no que tange às empresas estatais prestadoras de serviço público em regime de exclusividade ganhou destaque nos julgados mencionados no capítulo anterior, os julgados relativos à Companhia Docas do Rio de Janeiro, como também a Empresa de Correios e Telégrafos.

Existem inúmeros julgados mencionados no capítulo anterior em que foi possível perceber essa tendência publicista da Corte, porém fugiriam ao escopo deste trabalho, que é confrontar os pontos mais relevantes que concernem a esta nomenclatura que o Supremo Tribunal Federal vem concedendo às empresas estatais, de forma a confundir sua identidade.

Nos Recursos Extraordinários 220.906 e 229.969, os votos vencedores basearam-se no texto do artigo 12 do Decreto-lei 509 de 1969, além de afirmar que a ECT, por ser empresa estatal, não deveria ter seu regime equiparado ao regime das empresas privadas. Motta Pinto explicita 
em sua tese os argumentos específicos do voto vencedor, inclusive o do

Ministro Relator Maurício Corrêa:

(i) A ECT é pessoa jurídica equiparada à Fazenda Pública, explorando serviço de competência da União; (ii) não se aplica às estatais prestadoras de serviço público o preceito constitucional de equiparação com as empresas privadas (art. 173, parágrafos $1^{\circ}$ e $2^{\circ}$ ), não estando aquelas submetidas ao regime jurídico próprio destas; (iii) foi recepcionada a norma que prescreve a impenhorabilidade de bens, rendas e serviços da ECT, devendo a execução ocorrer mediante o sistema de precatórios $\left(\mathrm{CF} / 88\right.$, art. 100) ${ }^{114}$.

Em contraposição aos argumentos acima explicitados, o Ministro

Sepúlveda Pertence, que foi voto vencido, contra a impenhorabilidade de

bens da ECT, afirmou o seguinte:

(i) o preceito constitucional de equiparação das empresas estatais às privadas 9art. 173, parágrafos $1^{\circ}$ e $2^{\circ}$ ) aplica-se somente às estatais exploradoras de atividade econômica, que se distinguem das estatais prestadoras de serviços públicos; (ii) entretanto, da circunstancia de prestar serviço público não decorre a impenhorabilidade de todos os bens e rendas da estatal, mas tão somente dos que estejam diretamente afetados ao serviço; (iii) apesar da atividade-fim influenciar no regime jurídico das estatais em determinados aspectos, elas são constituídas, por opção do Estado, na forma de pessoas jurídicas de direito privado; (iv) os bens das estatais que não forem diretamente vinculados ao serviço público, entre os quais estão as suas rendas, são bens sujeitos ao regime jurídico comum, e portanto, penhoráveis; (v) a extensão as estatais, por lei, de prerrogativas do Poder Público, não pode configurar privilégios inconstitucionais; (vi) é privilégio inconstitucional a impenhorabilidade universal do patrimônio da ECT, promovida pelo art. 12 do Decreto-lei 509/69, que não permite opção alternativa ao sistema de precatórios para a execução judicial de seus débitos; (vii) o mecanismo de precatórios é um privilégio, que só pode ser explicado por se destinar à Fazenda Pública, donde estão excluídas as estatais; (viii) a lei ordinária não pode estender o sistema de precatórios a pessoas jurídicas de direito privado, ainda que integrantes da administração indireta, por configurar privilégio incompatível com o regime jurídico das empresas estatais; (iv) a mecânica de funcionamento dos precatórios depende da existência de orçamento legal e anual de despesas, que as estatais não possuem (...); (xii) no limite, a aplicação do sistema de precatórios só seria pertinente na hipótese de falência da ECT, quando suas dívidas se tornariam da União, que possui responsabilidade subsidiária quanto à elas ${ }^{115}$.

Deste modo, o Ministro coaduna com a corrente de que mesmo que essas empresas estatais prestem serviço público, foi opção estatal que elas obtivessem personalidade de direito privado, e sua natureza deve ser

\footnotetext{
114 PINTO, 2010b, p. 115-116.

115 Ibid., p. 117-118.
} 
respeitada, pois é a melhor forma de seu objeto social e de suas responsabilidades serem devidamente cumpridas.

Alexandre dos Santos de Aragão, no mesmo sentido do Ministro Sepúlveda Pertence, também em concordância com o defendido por Marçal Justen Filho, afirma que não seria a solução submeter as estatais ao regime de precatórios, seria uma maneira de proteger a inadimplência das mesmas. Justen Filho afirma:

\begin{abstract}
Adotar a tese, por exemplo, da submissão ao regime de precatório para as sociedades de economia mista fundado no argumento da prestação do serviço público conduziria, de modo inafastável, a que idêntica solução deveria ser adotada inclusive para as concessionárias privadas de serviço público. Afinal, o critério decisório seria a natureza da atividade desempenhada. Isso conduziria inclusive à eliminação do risco da insolvência para entidades privadas, o que é absolutamente incompatível com a natureza do próprio instituto da concessão ${ }^{116}$.
\end{abstract}

Assim como será explicado adiante, a Corte vem impondo o molde autárquico, relativo à Administração Direta, às empresas estatais prestadoras de serviço público em situação de exclusividade, especificamente e principalmente quando se fala de seu regime tributário e de execução.

\title{
3.1. A publicização das empresas estatais
}

As empresas estatais atuam em competição direta com o mercado no âmbito privado, propondo-se a uma competição igualitária entre ambas que disputam o mesmo mercado. Cabe mencionar o artigo 173, parágrafo $2^{\circ}$ da Constituição da República Federativa do Brasil, que proíbe que empresas públicas e sociedades de economia mista possam desfrutar de privilégios fiscais, por tais privilégios não serem estendidos ao mercado privado.

Ao longo do tempo, a doutrina e jurisprudência firmaram-se no sentido de que tal vedação se aplicaria somente às companhias que atuariam

\footnotetext{
116 JUSTEN FILHO, Marçal. Curso de Direito Administrativo. 9. ed. São Paulo: RT, 2013. p. 301302 In: ARAGÃO, Alexandre dos Santos de. Empresas Estatais. Rio de Janeiro: Forense. VitalBook file, 2017. p. 292.
} 
em regime de livre iniciativa, competição direta, e não àquelas empresas que possuíam regime econômico de monopólio, o que seria o caso da empresa pública que presta serviço delegado pelo Estado nos termos do artigo 150, inciso VI, alínea “a”, da Constituição da República Federativa do Brasil.

A abordagem diversa no que tange à natureza da atividade exercida e sua restrição no momento de leitura do artigo 173, CRFB, após a edição da Emenda n. 19, de 1998, prevê que exista lei nacional que estabeleça o estatuto jurídico das empresas estatais "que explorem atividade econômica de produção ou comercialização de bens ou de prestação de serviços", que se submeteriam ao regime das empresas privadas propriamente ditas.

Ao analisar a jurisprudência do Supremo Tribunal Federal, é possível verificar que tal dispositivo não é aplicável à empresa estatal prestadora de serviço público, o que, segundo Pinto Junior seria uma atitude que a captura ao regime público:

\begin{abstract}
A feição autárquica pode até fazer sentido para a empresa pública unipessoal que presta serviço público de competência do ente controlador, pois a situação é em tudo equivalente à prestação direta pelo Estado, tornando justificável o benefício da imunidade. O mesmo tratamento afigura-se descabido se a prestação do serviço público for intermediada por sociedade de economia mista com participação de acionistas privados, ou por empresa estatal atuando como concessionária de outra esfera de governo. Nesse caso, o interesse da companhia adquire autonomia própria, seja porque passa a abrigar anseios estranhos a administração pública, seja porque fica sujeito a influências externas a vontade do estado $^{117}$.
\end{abstract}

A doutrina reconhece que a sociedade de economia mista regida pela Lei $n^{\circ}$. 6404/76 seria a que explora atividade econômica competitiva, de livre iniciativa. Assim sendo, o Decreto-Lei 200/1967, menciona atividade econômica como forma de indicar a empresa pública e a sociedade de economia mista, de forma que não incluiria a prestação de serviço público.

A sugestão doutrinária seria de que tal estatuto, determinado pelo artigo 173, CRFB, deveria definir o sentido da atuação empresarial do

\footnotetext{
${ }^{117}$ PINTO JUNIOR, 2013, p. 210-211.
} 
Estado, assim como instituir os mecanismos de controle e adequasse à estrutura e funcionamento dos órgãos societários a feição publicista da companhia.

Em conexão ao tópico $2.1 \mathrm{em}$ que foram relatados os aspectos concernentes ao regime híbrido das empresas estatais, é importante destacar a existência de um movimento, denominado pela doutrina ${ }^{118}$ de 'pendular'.

Este movimento caracteriza-se pela aquisição de características próprias do direito privado pelas empresas estatais, o que garante uma maior liberdade em relação a atos a serem praticados no mercado privado, o que gera uma consequente agilidade e menor burocratização, um afastamento do que inibe a competitividade das mesmas.

No entanto, ao praticar atividades concernentes às empresas estatais de forma competitiva, com a liberdade descrita anteriormente, abusos passam a ser praticados pelos operadores das mesmas, o que atraiu a atuação dos órgãos de controle, tema que será aprofundado no tópico 3.2. Tal atuação permitiu que limitações fossem aplicadas às empresas estatais, tais como a realização de licitações e de concursos públicos ${ }^{119}$, a fim de evitar favorecimentos pessoais e econômicos de seus operadores.

Em decorrência desta limitação da liberdade, ocorre uma publicização do regime das empresas estatais, para que sejam evitados desvios que possam comprometer a finalidade pública que deveriam, a

\footnotetext{
${ }^{118}$ Alexandre dos Santos de Aragão define este movimento pendular como a discricionariedade ofertada as empresas estatais na liberdade da execução de seu objeto social e a incidência rígida dos mecanismos do direito público, tornando suas práticas mais engessadas e burocráticas. " $O$ direito administrativo deve evitar que, também dessa vez, se retorne ao citado movimento pendular entre a rigidez publicista e a relativa liberdade privatista para as estatais. $O$ que se deve buscar é, mantendo-se o máximo possível os meios para as estatais atuarem com agilidade no mercado, impor-lhes obrigações de demonstração de sua atuação republicana, o que de forma alguma deve ser confundido com a mera e automática aplicação das exigências formalistas típicas do direito administrativo. Quiséramos o direito administrativo tivesse tal capacidade moralizadora, na qual tantas vezes já falhou".

ARAG ÃO, 2017, p. 174.

119 É importante frisar, novamente, assim como realizado nos tópicos 2.3 e 2.3.1, 2.3.2, em que falamos sobre os regimes tributário e de execução, que abranger o regime de licitação, assim como o regime de pessoal das empresas estatais foge ao escopo do trabalho, o que não significa que possamos mencioná-los a título exemplificativo, já que estão correlacionados a esta interpretação constitucional trazida pelos julgados do Supremo Tribunal Federal.
} 
princípio, atender. Novamente, após a aproximação ao regime público, busca-se a ingerência do direito privado, a fim de que a empresas estatais sejam mais eficientes em sua atuação conjunta com o mercado.

Almeida Paiva, como menciona Alexandre Aragão, afirma que ocorre às empresas estatais, o mesmo que ocorreu com as autarquias, essa aproximação ao direito público que impede uma atuação libertária das empresas estatais:

À medida que tais sociedades se afastem das normas e da técnica das empresas privadas, despindo-se de suas características de independência de ação e consequente liberdade administrativa, deixarão de ser os instrumentos simples, flexíveis e eficientes e correrão, por conseguinte, o risco de falharem às suas finalidades. Torna-se, por isso mesmo, indispensável não se repita com tais tipos de sociedades o que ocorreu com as entidades autárquicas, que, segundo Oscar Saraiva, envelheceram precocemente: 'surgidas', diz êle, 'em maior número no quinquênio de 1937 a 1942, trazendo em si condições de independência de ação e liberdade administrativa que as tornavam instrumentos flexíveis e eficientes de ação, logo a seguir, as influências centralizadoras de padronização, uniformização e controle as alcançaram, tornando em muitos casos sua administração quase tão rígida quanto a do próprio Estado, e fazendo desaparecer as razões de conveniência que originaram sua instituição'. As sociedades de economia mista e as chamadas empresas públicas evidentemente haverão de subsistir como instrumentos jurídicos a serviço do Estado moderno, no seu mister e empenho de atender aos interesses gerais da coletividade, mas isto realmente só será possível na medida em que se mantiverem fiéis às suas características de empresa privada, de forma a não permitir sua transformação em simples órgãos da administração pública descentralizada ${ }^{120}$.

A tendência de publicização, que pode ser denominada como maximalista, ficou refletida no novo Estatuto das empresas estatais, o qual seguiu esta roupagem com o objetivo de ser a resposta ao momento atual do país, em que diversos episódios notórios de corrupção na estrutura das mesmas vêm sendo revelados.

Por esta razão, buscou-se cercar as empresas estatais de controle, reduzindo seu espaço discricionário, ampliando os mecanismos de

\footnotetext{
${ }^{120}$ PAIVA, Alfredo de Almeida. As sociedades de economia mista e as empresas públicas como instrumentos jurídicos a serviço do Estado. In: Revista de Direito Administrativo (Seleção Histórica). v. 1. p. 319-320, 1991.

ARAGÃO, Alexandre dos Santos de. Empresas Estatais. Rio de Janeiro: Forense. VitalBook file, 2017. p. 170.
} 
governança corporativa ${ }^{121}$. Neste sentido, Rosilho explica a distinção entre

o que seria o minimalismo e o maximalismo:

O pano de fundo da oposição ressaltada no título deste tópico - maximalistas versus minimalistas - pode ser sintetizado nas seguintes indagações: Como deveria ser o modelo legal das licitações públicas? De que forma as regras jurídicas poderiam contribuir para a construção de um bom sistema de contratações públicas? A estas perguntas os maximalistas responderiam afirmando que um bom modelo legal seria aquele que procurasse antever, por meio de dispositivos legais, as escolhas e caminhos que pudessem levar a uma boa contratação pública. A aposta desse grupo é a de que a lei deveria ser minuciosa, detalhista e abrangente, dever ser capaz de cercar a discricionariedade da Administração Pública. Os minimalistas, por outro lado, responderiam às indagações afirmando que um bom modelo legal seria aquele que fosse capaz de gravar na lei os elementos essenciais à realização das licitações, suas diretrizes fundamentais. A ideia, neste caso, é a de que a lei deveria limitar-se a dizer o básico e que deveria evitar o casuísmo e a minudência. As decisões pontuais sobre as contratações públicas deveriam ser tomadas noutro âmbito, que não o legal ${ }^{122}$.

Alexandre dos Santos de Aragão, no entanto, discorda que trazer esta rigidez do Direito Administrativo seja o caminho mais adequado para a proteção das empresas estatais contra as práticas corrompidas, e esta é a corrente a qual seguimos nesta monografia:

Não nos parece que o recrudescimento dos mecanismos tradicionais do Direito Administrativo, com toda a sua rigidez, seja o remédio mais adequado para essas mazelas, sobretudo no âmbito das empresas estatais. Em primeiro lugar, porque, se essa fosse a melhor solução, esses mesmos vícios não ocorreriam nas entidades de direito público, em princípio submetidas a todas as exigências típicas de direito administrativo, o que, como é de conhecimento comum, infelizmente não é o caso. Em segundo lugar, porque, além de não conseguir evitar desvios de conduta, ao prejudicar-lhes a agilidade e a flexibilidade inerentes à gestão empresarial, pode acabar comprometendo ainda mais o atendimento aos objetivos institucionais das estatais, sobretudo das que atuam em mercados competitivos. Nem o regime publicista nem o privado são infensos ou mais adequados ontologicamente a combater malversações. Essas patologias envolvem aspectos éticos, históricos e sociológicos sobre os quais o Direito - e muito menos o Direito Administrativo isoladamente - não possui integral gestão ${ }^{123}$.

O propósito deste tópico é afirmar que o retorno completo para a burocratização e a rigidez dos meios como as empresas estatais poderiam

\footnotetext{
${ }^{121}$ A governança corporativa foi o objeto de estudo do tópico 1.1.1. desta monografia.

${ }^{122}$ ROSILHO, André. Licitação no Brasil. São Paulo: Malheiros Editores, 2013.

SUNDFELD, Carlos Ari. (Coord.). Parcerias Público-Privadas. 2a ed. São Paulo: Direito GV, Malheiros Editores, 2011. p. 104-105.

${ }^{123}$ ARAGÃO, 2017, p. 173-174.
} 
negociar, seria um retrocesso. Carlos Ari Sundfeld, e o segue Alexandre dos

Santos de Aragão, afirmam que o direito mais aplicável às empresas estatais seria o "Direito Administrativo dos Negócios".

Na Administração Pública o ambiente mais propício ao DAN é o dos organismos que disputam mercado (empresas estatais que concorrem com empresas do setor privado) ou que são responsáveis por serviços cuja falta ou deficiência possa levar à convulsão popular imediata (transporte público, segurança, coleta de lixo) ou a perdas eleitorais (saúde, educação, financiamento agrícola etc.). Também os momentos de crise econômica e política aguda são adequados para ela. Aí, são muito fortes os estímulos para a busca de resultados e, por isso, não funcionam do mesmo modo os mecanismos de autopreservação dos agentes públicos, típicos do DAC. Para fundamentar suas práticas, o discurso do DAN baseia-se em máximas ou figuras como continuidade do serviço público, ordem pública, eficiência, empresa estatal, parcerias com o setor privado, Terceiro Setor, direitos sociais, interesse público, emergência, calamidade, etc ${ }^{124}$.

O mesmo autor denota a bipolaridade ${ }^{125}$ do Direito Administrativo, pois que ambos os lados de forma extrema seriam prejudiciais ao funcionamento das estatais. O que deveria ser priorizado pelo próprio Supremo Tribunal Federal em seus julgados, seria preservar o caráter privado da empresa estatal, tal como é, e seguir a orientação constitucional para que cumpra adequadamente seu objeto social.

No próximo tópico iremos analisar os efeitos deste pretexto que o Supremo Tribunal Federal vem utilizando para defender a prestação de serviços públicos, e a discordância desta tendência publicizante que as decisões vêm apoiando.

\footnotetext{
124 SUNDFELD, Carlos Ari. O Direito Administrativo entre os clipes e os negócios. In: ARAGÃO, Alexandre dos Santos de; MARQUES NETO, Floriano de Azevedo (Coord.). Direito Administrativo e seus novos paradigmas. Belo Horizonte: Fórum, 2008. p. 148.

${ }^{125}$ Carlos Ari Sundfeld explica esta bipolaridade referida acima da seguinte forma: "Antes de tudo esta advertência: não se pode ignorar o caráter bipolar do direito administrativo, tomando um só polo como dogma e lançando o outro às feras. A militância em torno da bandeira do direito administrativo dos clipes teve um importante papel, mas está virando religião monoteísta em guerra santa. O direito administrativo dos negócios não é invenção recente de mentes deturpadas, mas parte necessária da história e da prática do direito administrativo. Talvez estejam nele algumas das soluções para os impasses governamentais recentes e para fazer de nosso ramo o direito administrativo do desenvolvimento que tanto se reclama".
}

SUNDFELD, 2014, p. 152. 


\subsubsection{A jurisprudência do Supremo Tribunal Federal e o backlash $h^{126}$}

A crise mencionada teve seu início, principalmente devido ao firme posicionamento do Supremo Tribunal Federal com relação ao formato das Empresas Estatais e seu afastamento do modelo originário empresarial em alguns quesitos.

O principal propósito da guinada jurisprudencial do Supremo Tribunal Federal foi o de uniformizar os regimes das entidades que compõe a administração indireta, de forma que as Empresas Estatais que prestem serviços públicos ou as que exploram a lucratividade sejam equivalentes em relação às prerrogativas.

A Corte vem mitigando as características empresariais, no sentido de afastar as Empresas Estatais prestadoras de serviços públicos de seu formato empresarial, já a tendência legislativa é oposta a isto. Desta forma, este julgado ${ }^{127}$ do Supremo impôs um obstáculo ao legislados.

Ora, ficou reafirmado por meio do voto da Relatora Ministra Rosa Weber na Ação Civil Originária $\mathrm{n}^{\circ} 811$ em Agravo Regimental ${ }^{128}$, que a ECT possui imunidade tributária recíproca, mesmo nas atividades concorrenciais, justamente por não buscarem a obtenção do lucro, mas sustentam-se somente pelo subsidio que advém do serviço postal.

\footnotetext{
${ }^{126}$ A professora Marianna Montebello Willeman, em seu artigo "Constitucionalismo Democrático, Backlash E Resposta Legislativa Em Matéria Constitucional No Brasil" menciona o autor Cass R. Sunstein e sua definição do que seria o backlash: "Let us define "public backlash", in the context of constitutional law, in the following way: Intense and sustained public disapproval of a judicial ruling, accompanied by agressive steps to resist that ruling and remove its legal force. In cases of backlash, many minds have rejected the Court's decision, and they have done so with conviction", em tradução livre realizada pela autora "Deixe-nos definer o backlash public, no context do direito constitucional, da seguinte forma: reprovação intensa e sustentada de uma decisão judicial, acompanhada de medidas agressivas para se resistir a essa decisão e se retirar sua força legal. Em casos de backlash, um grande número de pessoas rejeita a decisão da Corte e o faz com Conviç̧ão".

SUNSTEIN, Cass R. A Constitution of Many Minds: why the founding document doesn't mean what it meant before? Princeton: Princeton University Press, 2009. p. 123 apud WILLEMAN, WILlEMAN, Marianna Montebello. Constitucionalismo Democrático, Backlash e Resposta Legislativa em Matéria Constitucional no Brasil. 33ª ed. REDE. p. II-6, jan/fev/mar 2013.

${ }^{127} \mathrm{O}$ julgado pioneiro a que nos referimos neste ponto é o posicionamento do Supremo Tribunal Federal em relação à ECT, em 2004. O qual trouxe este viés autarquizante no sentido da concessão da imunidade recíproca.

${ }^{128}$ STF, ACO 811, AgRg/DF, Rel. Ministra Rosa Weber, Primeira Turma, Julgado em: 21 jun. 2016.
} 
Existe uma tendência de submeter às associações societárias entre Empresas Estatais e particulares, há algumas regras especiais, mas há menos tendência de querer olhar a especialidade como um princípio, um dado necessário, justamente porque a aceitação da ideia de Empresa no mundo Estatal importou uma quebra de paradigma. Em matéria de legislação contratual para o Estado, pode-se notar a ocorrência de inflação legislativa.

A Constituição da República Federativa do Brasil expressou a ideia de que as Empresas Estatais não deveriam ter privilégios, o fato é que, em boa medida, há Empresas Estatais que de fato trabalham num ambiente de competição sem prerrogativas. No entanto, nos últimos anos, a Suprema Corte subverteu essa ideia ao criar uma jurisprudência para privilegiar Empresas Estatais prestadoras de serviço público e é curioso que tenha feito isso exatamente enquanto a sociedade estava vivendo a era do Direito Administrativo Empresarial, em que se estava trabalhando de forma elaborada na construção do regime jurídico da administração pública que realiza negócios, inclusive utilizando-se das Empresas Estatais.

O Direito Administrativo estava reconhecendo a importância da atuação empresarial destas empresas, desenvolvia o controle coerente com seus negócios, pode-se citar a título exemplificativo a questão da governança corporativa, o aprimoramento dos Conselhos de Administração e o modo como o governo se posiciona.

Atualmente, advinda do direito norte-americano, a tese do backlash vem sendo adotada no Brasil, assim como Marianna Montebello Willeman destaca em seu artigo, que possui como base o Direito Constitucional, mas que os efeitos do instituto são similares, ou seja, as decisões advindas dos tribunais deixaram de ser incontestáveis e passaram a ser debatidas, tal como elucida:

Percebe-se que o backlash desconstruiu a presunção usualmente aceita de que as decisões judiciais adotadas em matéria constitucional devem ser objeto de deferência sem protesto e, portanto, desafia a própria titularidade, por parte das 
instâncias judiciais, da última palavra quanto ao significado da Constituição. Atualmente, a abordagem acadêmica que tem marcado a apreciação desse fenômeno busca investigar como deve ser a atuação das cortes de justiça diante dos riscos que um backlash pode trazer. Em outras palavras: devem os juízes simplesmente ignorar os efeitos políticos e sociais indesejados que uma decisão judicial pode vir a provocar e decidir sem levar essa circunstância em consideração ou, inversamente, os riscos de backlash devem ser sopesados antes da adoção de uma decisão judicial, justificando e conduzindo a uma postura minimalista por parte do judiciário ${ }^{129}$.

No entanto, exatamente nesse período a Corte criou uma jurisprudência surpreendente que diz que se a Estatal explorar serviço público possui imunidade e essas estatais se submeteriam ao regime do precatório, sem precatório. Sendo que, a Constituição afirma exatamente o oposto a isto.

À época, no Recurso Extraordinário no 599.628/DF ${ }^{130}$, o Ministro Joaquim Barbosa aquiesceu à corrente atual de abonar a diferenciação entre as estatais no que tange à sua atividade desempenhada, no momento em que estava em voga a discussão sobre o regime de precatórios a ser aplicado à Eletronorte:

(...) A meu sentir, a circunstância de o modelo de geração e fornecimento de energia admitir a livre iniciativa e a concorrência é preponderante para resolução da controvérsia. De fato, o exercício de atividade com intuito lucrativo, sem monopólio estatal, deve submeter-se aos instrumentos de garantia do equilíbrio concorrencial, nos termos do art. $173, \S 1^{\circ}$, II e $\S 2^{\circ}$ da Constituição. Em especial, a empresa pública e a sociedade de economia mista devem despir-se das prerrogativas próprias do Estado nas hipóteses em que incursionarem na seara de exploração econômica. A importância estratégica da atividade não afasta a sua conformação à legislação vigente. (...) Portanto, a extensão à sociedade de economia mista, de prerrogativa constitucional inerente ao Estado tem o potencial para desequilibrar artificialmente as condições de concorrência, em prejuízo das pessoas jurídicas alheias a qualquer participação societária estatal.

Fidalgo, ao analisar o julgado do Supremo Tribunal Federal, despertou a atenção dos doutrinadores no sentido de que a jurisprudência da Corte poderia estar passando por um momento revisional:

Vê-se, portanto, que o tema encontra-se em processo de revisão. É bastante provável que, a partir daí, seja sedimentado o entendimento de que o art. 173 da

\footnotetext{
${ }^{129}$ WILLEMAN, 2013, p. II-6.

${ }^{130}$ STF, RE no 599.628/DF, Plenário, Rel. Ministro Ayres Britto, Julgado em: 25 mai. 2011.

SILVA, p. 241 In: ARAGÃO, 2015, p. 302.
} 
Constituição Federal se aplica a todas as empresas estatais exploradoras de atividades econômicas (em sentido lato) em regime de concorrência. ${ }^{131}$.

Um recente julgado da Corte, do presente ano de 2017, a Ação Civil Originária $\mathrm{n}^{\circ} 571$ em Agravo Regimental ${ }^{132}$, por meio da relatoria do Ministro Dias Toffoli, baseou-se em afirmar que o STF vem aplicando a tendência publicista de forma cautelosa e não se estende a todo e qualquer regime das estatais, como ele mesmo afirma:

\begin{abstract}
Rememore-se que o mais longe a que chegou esta Corte diz respeito aos casos em que se admitiu a equiparação das estatais prestadoras de serviço público em caráter exclusivo a entidades de direito público da Administração Indireta para fins de reconhecimento da imunidade tributária. A hipótese dos autos, contudo, não se harmoniza com tal situação fática. Reconhecer que um ente público não deve tributar outro quando em foco a prestação de serviços públicos é conclusão que se coaduna com o modelo de federalismo colaborativo adotado pela Constituição Federal. Quer esta Corte registrar, em tais julgados, que o serviço público - seja prestado direta ou indiretamente pelo Estado - não deve estar sujeito a ônus impostos por outros entes, sob pena de se criarem dificuldades no atendimento das necessidades essenciais da coletividade, fim maior daquela espécie de atuação prestacional. A cada ente é atribuído um conjunto de obrigações constitucionais, em sua essência, concretizado pela prestação de serviços públicos. O que está Corte em última instância está por definir com a jurisprudência apontada (em matéria de imunidade tributária) é a preservação das competências de cada ente e, nesse passo, do próprio modelo federativo.
\end{abstract}

No caso em questão, como se tratava de repartição de receitas, o Supremo Tribunal Federal possuiu o intuito de proteger o pacto federativo. No entanto, admite que vem sim concedendo a imunidade tributária recíproca quando se está diante de uma empresa estatal que preste serviço público.

Podemos dizer aqui que o aspecto comum entre as decisões mencionadas nesta pesquisa, proferidas pelo STF, é que as empresas estatais prestadoras de serviços públicos possuem direito aos privilégios. Deste modo, acredita-se que elas possuem acesso às prerrogativas do Estado por meio da utilização do critério subjetivo.

\footnotetext{
${ }^{131}$ FIDALGO, 2012, p. 198.

${ }^{132}$ STF, ACO 571, AgRg/SP, Rel. Ministro Dias Toffoli, Plenário, Julgado em: 07 mar. 2017.
} 
A utilização deste critério implica nas seguintes problemáticas: o resguardo do patrimônio dessas empresas estatais e não do serviço público propriamente dito, no caso de a empresa estatal estar em concorrência com o mercado privado, prejudica seu desempenho e a simples sensação pela Corte de que há atividade pública sendo prestada pela estatal já é motivo para uma decisão que conceda privilégios.

Se o critério objetivo fosse utilizado pelo STF, no caso da impenhorabilidade de bens, só poderiam ser impenhoráveis aqueles bens que fossem realmente afetados pelo serviço público prestado. Já em relação ao regime tributário, a imunidade tributária recíproca não seria concedida, justamente porque a Constituição não inclui as empresas estatais em seu rol exaustivo e não protege serviços públicos tarifados.

Henrique Motta Pinto ${ }^{133}$, que realiza uma pesquisa profunda acerca do posicionamento do STF em relação ao tema aqui exposto, afirma que a dúvida possivelmente suscitada seria a seguinte: se a Corte concede tais privilégios às estatais e não protegem o serviço público em si, mas sim seu patrimônio, e se elas fossem concessionarias de serviço público? Seriam aptas a desfrutar dos privilégios? A resposta, segundo o autor seria completamente negativa. Até porque, o Supremo, inequivocamente, afirma que os privilégios concedidos são em razão de seu pertencimento à administração pública.

Os principais privilégios concedidos, no que tange a impenhorabilidade de bens e a imunidade tributária recíproca, foram concedidos com fundamentação constitucional e de maneira necessária. Assim, um dos problemas que queremos indicar decorrente deste posicionamento jurisprudencial é o de que a gestão pública fica prejudicada, tanto no âmbito de atuação do poder legislativo quanto do executivo.

Neste sentido, a partir do momento em que o STF torna necessário o estabelecimento de privilégios para as estatais prestadoras de serviço

\footnotetext{
${ }^{133}$ PINTO, 2010b, p. 177.
} 
público, ele admite que sua personalidade de direito privado não impeça a incidência do regime público. O que queremos dizer aqui é que a vontade estatal no sentido de criar uma empresa é menosprezada.

Resta claro que, para a Corte, o formato empresarial da empresa estatal prestadora de serviço público não é adequado. Devido a este pensamento, aproxima ao regime jurídico autárquico.

Ora, se o Estado adotou a forma empresarial por meio de uma empresa estatal justamente porque não possuía a intenção de criar uma autarquia, a personificação do direito público. O Supremo Tribunal Federal vem, por meio de suas decisões, relativizando essa vontade proveniente do Estado e descaracterizando as empresas estatais.

Parece-nos que, sob o ponto de vista da Corte, que a prestação de serviço público seria incompatível ao regime jurídico empresarial da empresa estatal e este posicionamento vem se expandindo. Em oposição a isto, temos a produção legislativa ${ }^{134}$ que busca a valorização da natureza empresarial das empresas estatais.

\subsection{O controle exercido pelos órgãos de controle nas Empresas Estatais}

Destaca-se que a Corte não possui certeza de como se realiza o controle de administração pública que realiza negócios ${ }^{135}$. Não existe a crença de que o Tribunal de Contas da União possuiria a lógica de controlar as Empresas Estatais, adaptando-se aos negócios decorrentes das mesmas.

\footnotetext{
${ }^{134}$ O próprio Estatuto das Estatais, a Lei 13.303 de 2016. Além dele, temos a Lei no 8.987 de 1995, como também a Lei ${ }^{\circ} 11.079$ de 2004.

135 Afirmamos isto com base na obra do doutrinador Rafael Carvalho Rezende de Oliveira o qual afirma: "Tradicionalmente, o STF afastava as estatais do controle pelo tribunal de contas, tendo em vista o patrimônio o patrimônio privado dessas entidades, o que afastaria a aplicação do art. 71, II, da CRFB que prevê o referido controle em relação às "contas dos administradores $e$ demais responsáveis por dinheiros, bens e valores públicos da administração direta e indireta". (Neste sentido: Informativos de jurisprudência do STF 250, 259 e 260)".

OLIVEIRA, Rafael Carvalho Rezende de. Curso de Direito Administrativo. $4^{\mathrm{a}}$ ed. rev. atual. e ampl. Rio de Janeiro: Forense; São Paulo: Método, 2016. p. 127-128.
} 
Ao longo do tempo ocorreu uma mudança de perspectiva e o Supremo Tribunal Federal, em seus julgados ${ }^{136}$, enxerga que seria danoso ao erário público não exercer o controle sobre essas companhias, por esta razão passou a admitir que o controle fosse exercido, sem realizar a distinção entre as atividades por elas exercidas.

Vale mencionar a recente decisão proferida em 2017 pelo Supremo Tribunal Federal no Mandado de Segurança $n^{\circ} 26297$ em Agravo Regimental ${ }^{137}$, o qual concordou com a decisão do Tribunal de Contas da União que entendeu ser ilegal o pagamento a título de participação nos lucros da Eletronorte aos empregados admitidos após 1983. Por assim dizer:

É que, examinadas as contas, pode o TCU aplicar aos responsáveis, em caso de ilegalidade de despesa ou irregularidade de contas, as sanções previstas em lei, que estabelecerá, entre outras cominações, multa proporcional ao dano causado ao erário. A Corte de Contas deve, ainda, assinar prazo para que o órgão ou entidade adote as providências necessárias ao exato cumprimento da lei, se verificada ilegalidade. São os gestores e demais responsáveis pelo dinheiro público os destinatários das sanções e comandos emitidos pelo TCU.

Não se sabe a forma como o controle será exercido de maneira adequada e concernente ao papel das Empresas Estatais no contexto socioeconômico atual. Para que ocorra o controle adequado, será necessário que o Direito seja aprimorado para que possa distinguir situações relativas às empresas que realizam negócios, pois se caracterizou da seguinte forma, ou o controle é exercido da maneira tradicional ou essas empresas não são controladas, o que é periclitante.

De todo modo é importante ressaltar que o objetivo deste tópico não é exaurir todos os tipos de controle incidente às estatais, que são exercidos pelo Poder Legislativo, Poder Executivo, Poder Judiciário, Tribunais de Contas ou até mesmo o controle societário exercido pelo chefe do Poder Executivo. Tão somente será comentar o que mais se liga ao tema deste

\footnotetext{
${ }^{136}$ STF, Tribunal Pleno, MS 25.092/DF, Rel. Ministro Carlos Velloso, Julgado em: 17 mar. 2006. STF, Tribunal Pleno, MS 24.423/DF, Rel. Ministro Gilmar Mendes, Julgado em: 20 fev. 2009, Informativo de Jurisprudência do STF $\mathrm{n}^{\circ} .519$.

${ }^{137}$ STF, MS n 26297/DF. Segunda Turma. Rel. Ministro Edson Fachin, Julgado em: 16 mar. 2017.
} 
trabalho e será profundamente analisado em tópico posterior, que será o controle pelos Tribunais de Contas.

Iremos nos debruçar sobre as controvérsias relevantes acerca deste tema, a fim de afirmar que deverá ser utilizado de forma dosada, para que não torne engessada a operação das empresas estatais.

Carolina Barros Fidalgo expressa que já é pacífico o fato de que somente o exercício do controle interno societário não é suficiente para garantir que a empresa estatal cumpra seu objeto social. Por isso, é necessário que incida um controle externo, porém não de forma exagerada. A autora menciona a crítica de Pedro Paulo de Almeida Dutra:

Em vista disso, tem-se que "os controles exercidos sobre a empresa pública devem salvaguardar a necessária autonomia destas últimas. (...) muito embora dependa do Poder Público, a empresa pública não merece ser denominada de empresa a não ser que possua uma vida própria e persiga livremente o seu objeto". Mas deve ser feita a ressalva de que a autonomia a ser preservada não é absoluta, mas a possível, em se considerando que essas sociedades são criadas para uma determinada finalidade pública: "a autonomia da empresa está condicionada ao papel instrumental que lhe é atribuído".

As empresas estatais são criadas por meio de autorização legislativa ${ }^{138}$, além disso, o controle exercido pelo Poder Legislativo se manifesta por meio de edição de leis que autorizem as privatizações ou até mesmo a disposição constitucional que prevê a fiscalização dos atos da administração indireta pelo Congresso Nacional, o qual é auxiliado pelo Tribunal de Contas da União. Existe também a possibilidade de o Poder Legislativo aprovar ou não o orçamento ${ }^{139}$ da mesma.

O controle exercido pelos Tribunais de Contas, assim previsto nos artigos 70 e 71 da Constituição Federal, como também nos artigos 85 a 87

\footnotetext{
${ }^{138}$ Constituição Federal, artigo 37, inciso XIX.

${ }^{139}$ Carolina Barros Fidalgo menciona a crítica de Dallari, o qual afirma que este controle deverá ser exercido de forma bastante restrita.

DALlARI, Adilson Abreu. O Controle Político das Empresas Públicas. In: A Empresa Pública no Brasil: uma abordagem multidisciplinar. Brasília: IPEA, 1980. p. 184. apud FIDALGO, Carolina Barros. $O$ Estado empresário: regime jurídico das tradicionais e novas formas de atuação empresarial do estado na economia brasileira. Rio de Janeiro. 2012. 370 f. p. 166. Dissertação de Mestrado em Direito. Faculdade de Direito, Universidade do Estado do Rio de Janeiro, 2012. p. 234.
} 
do Estatuto das Estatais, deveria se adequar as atividades econômicas que a empresa estatal exerce. Não deverá, pois, incidir um controle que seria aplicado às outras entidades da Administração Pública, isso engessaria seus atos. Alexandre dos Santos de Aragão menciona dois possíveis problemas decorrentes de um controle exacerbado dos Tribunais de Contas, que seriam eles:

Além do problema do comprometimento da autonomia decisória e negocial, decorrente do receio de futuras penalizações, engessando pelo medo a agilidade da estatal, outro problema decorrente da sujeição dessas empresas ao controle externo clássico incidente sobre os demais órgãos e entidades públicas diz respeito ao inexorável aumento dos seus custos ${ }^{140}$.

Ora, seguimos o entendimento de Alexandre dos Santos de Aragão, pois que uma empresa estatal engessada pelo controle exacerbado não será competitiva no mercado privado, que atua em sua grande parte sob a influência do princípio da livre iniciativa, assim como a busca por oportunidades lucrativas. A consequência deste controle exacerbado seria a perda de competitividade com o mercado privado, como explica Aragão:

\begin{abstract}
Note-se que essas desvantagens competitivas não se refletem apenas na gestão interna da estatal, mas também nas suas relações com seus parceiros comerciais, sobretudo com aqueles para os quais faça pagamentos, a serem também indiretamente controlados pelos tribunais de contas. O agente econômico, na busca constante da maximização de seus lucros, responde de forma racional a estímulos. Para ele, a possibilidade de fiscalização (e sancionamento) dos tribunais de contas é mais um elemento das relações de custo-benefício com as quais vai ter que lidar na condução dos seus negócios. O natural é que os empresários monetizem o risco criado, repassando-o para o preço final, a ser pago pela estatal. Assim, o aumento dos riscos em um contrato repercute no preço final do mesmo. Na economia, todo risco é precificado. Dito de outra forma, esse controle pode trazer o efeito colateral de onerar - e dificultar - a contratação pelas empresas públicas e sociedades de economia mista, em razão da intensificação dos riscos do contrato e do consequente encarecimento do preço dos serviços a elas prestados ${ }^{141}$.
\end{abstract}

Existe aqui em voga, quando se trata de controle a ser exercido pelos Tribunais de Contas, a necessidade da observância do princípio da economicidade. Alexandre dos Santos de Aragão menciona o julgado do

\footnotetext{
${ }^{140}$ ARAGÃO, 2017. p. 371.

${ }^{141}$ Ibid., p. 371-372.
} 
Tribunal de Contas da União que já demonstra um parâmetro, em que se respeita o caráter privado da empresa estatal.

Sob essa inspiração, o Tribunal de Contas da União - TCU já constatou a necessidade, diante de caso concreto, de afastar a fiscalização em contratos celebrados por entidades sujeitas a seu controle por força do princípio da eficiência em sua vertente da economicidade, afirmando que "o cumprimento do princípio da legalidade não pode, entretanto, resultar em invalidação do princípio constitucional da economicidade". Em vista disso, dispensou a empresa "das diligencias, audiências previas e citações solicitadas", pois "a estrita e formal adequação do contrato, implicaria, inexoravelmente, gastos superiores ao ocorrido". Concluiu o Tribunal que "não se pode falar em dano ao Erário já que se verificou ter sido plenamente atendido o princípio constitucional da economicidade ${ }^{142}$ ",

Iremos abranger no próximo tópico a combinação que deverá ser realizada entre os artigos 87 e 90 do Estatuto das Estatais, os quais abrangem o controle exercido pelos Tribunais de Contas, visto que, como Alexandre dos Santos de Aragão bem diz, o artigo $87^{143}$ busca uma "presunção de legitimidade às avessas", e o artigo $90^{144}$ estabelece, como o próprio autor diz, o "Princípio da Deferência".

\footnotetext{
142 Decisão 753/1996 - Plenário. In: ARAGÃO, Alexandre dos Santos de. Empresas Estatais. Rio de Janeiro: Forense. VitalBook file, 2017. p. 372-373.

${ }^{143}$ Art. 87. O controle das despesas decorrentes dos contratos e demais instrumentos regidos por esta Lei será feito pelos órgãos do sistema de controle interno e pelo tribunal de contas competente, na forma da legislação pertinente, ficando as empresas públicas e as sociedades de economia mista responsáveis pela demonstração da legalidade e da regularidade da despesa e da execução, nos termos da Constituição. § 1 Qualquer cidadão é parte legítima para impugnar edital de licitação por irregularidade na aplicação desta Lei, devendo protocolar o pedido até 5 (cinco) dias úteis antes da data fixada para a ocorrência do certame, devendo a entidade julgar e responder à impugnação em até 3 (três) dias úteis, sem prejuízo da faculdade prevista no $\S 2^{\circ}$. $§ 2^{\circ}$ Qualquer licitante, contratado ou pessoa física ou jurídica poderá representar ao tribunal de contas ou aos órgãos integrantes do sistema de controle interno contra irregularidades na aplicação desta Lei, para os fins do disposto neste artigo. § 3 o Os tribunais de contas e os órgãos integrantes do sistema de controle interno poderão solicitar para exame, a qualquer tempo, documentos de natureza contábil, financeira, orçamentária, patrimonial e operacional das empresas públicas, das sociedades de economia mista e de suas subsidiárias no Brasil e no exterior, obrigando-se, os jurisdicionados, à adoção das medidas corretivas pertinentes que, em função desse exame, lhes forem determinadas.

${ }^{144}$ Art. 90. As ações e deliberações do órgão ou ente de controle não podem implicar interferência na gestão das empresas públicas e das sociedades de economia mista a ele submetidas nem ingerência no exercício de suas competências ou na definição de políticas públicas.
} 


\subsection{0 advento do novo estatuto jurídico - A Lei no. 13.303 de 30 de julho de 2016 e a tentativa de uniformização dos regimes jurídicos das Empresas Estatais}

O artigo 173 da Constituição da República Federativa do Brasil afirma que existe a necessidade de um estatuto das Empresas Estatais, sendo elas as companhias que realizam atividades econômicas. No entanto, este novo estatuto surgiu com o intuito de unificar os regimes, sendo ele aplicado não somente as que exploram atividades econômicas, como também às prestadoras de serviço público.

Ressalta-se que fugiria ao escopo deste trabalho a abordagem de todos os temas concernentes às empresas estatais presentes neste Estatuto $^{145}$. Busca-se analisar temas aqui já explicitados, por exemplo, o fortalecimento da governança corporativa e também como ficou estabelecido o controle a ser exercido pelos Tribunais de Contas.

Certo dizer que este Estatuto sofreu grande influência proveniente do atual contexto brasileiro, as empresas estatais passando por um momento crítico, como Alexandre dos Santos de Aragão afirma:

Pelo déficit público e excessos de interferências governamentais em seus preços, e, também, pela Operação Lava Jato, que, como se sabe, tem como objeto esquemas de corrupção ocorridos, sobretudo em empresas estatais, mormente na Petrobras ${ }^{146}$.

\footnotetext{
${ }^{145} \mathrm{Um}$ dos temas considerados relevantes para os doutrinadores, dentre eles, Alexandre dos Santos de Aragão, seria o tema das licitações. Por mais que o tema tenha sofrido alterações após o advento deste Estatuto, alguns positivos e outros nem tanto, pois se encontra mais próximo da Lei 8.666 de 1993 do que ao Código Civil, como o próprio autor expressa, não será abordado no presente tópico, o qual visa uma abordagem sucinta sobre temas já aprofundados anteriormente neste mesmo trabalho. Ficamos então com o comentário de Alexandre dos Santos de Aragão sobre o tema: "Um dos temas mais relevantes por ele disciplinado - o das licitações e contratos -, tem tratamento de vigência específico, com a entrada em vigor bem postergada: apenas as licitações iniciadas e os contratos celebrados após vinte e quatro meses de sua publicação serão por ele regidos (art. 91, §3..$^{\circ}$. Somente para as estatais que virem a ser criadas após a edição do Estatuto é que o seu regime licitatório e contratual terá incidência imediata, já que o citado § $3 .^{\circ}$ se refere ao prazo de vinte e quatro meses fixados pelo caput, e este se refere apenas às estatais preexistentes". ARAGÃO, 2017, p. 176.

${ }^{146}$ Ibid., p. 175.
} 
Por este motivo, no que tange à governança corporativa, a qual foi aplicada com intensidade no âmbito federal por meio do Decreto 8.945 de 27 de dezembro de 2016, as normas relativas à transparência e também à designação de dirigentes ganharam enorme notoriedade. O artigo 17, parágrafo $2^{\circ}$, incisos I e II $^{147}$, deste Estatuto, a título exemplificativo, exclui a nomeação de dirigentes que integrem partidos políticos.

No que tange ao controle dos atos das empresas estatais, o artigo 87 e o 90 trazem, a partir de uma complementação de ideias, a noção da business judgement rule ${ }^{148}$ para a doutrina brasileira. Em suma, trata-se de uma legitimação dos atos de gestão, parte-se do ponto de vista de que existe uma boa-fé, e assim como no direito norte-americano ${ }^{149}$, só seria objeto de controle se for manifesta a ilegalidade.

Como já afirmado no tópico específico de controle pelos Tribunais de Contas, e não iremos adentrar novamente assuntos já expostos, este estatuto buscou preservar o aspecto empresarial, de gestão dessas empresas. Contrariamente a jurisprudência do Supremo Tribunal Federal, que passou a aplicar o controle de forma ostensiva, sem diferenciar as atividades por elas exercidas.

Conclui-se que o significado deste estatuto para o Direito Administrativo traz consigo a ideia do hibridismo dos regimes. A fim de preservar um perfil eficiente e trazer a economicidade para as empresas

\footnotetext{
${ }^{147}$ Art. 17. Os membros do Conselho de Administração e os indicados para os cargos de diretor, inclusive presidente, diretor-geral e diretor-presidente, serão escolhidos entre cidadãos de reputação ilibada e de notório conhecimento, devendo ser atendidos, alternativamente, um dos requisitos das alíneas "a", "b" e "c" do inciso I e, cumulativamente, os requisitos dos incisos II e III: Art. 17. Os membros do Conselho de Administração e os indicados para os cargos de diretor, inclusive presidente, diretor-geral e diretor-presidente, serão escolhidos entre cidadãos de reputação ilibada e de notório conhecimento, devendo ser atendidos, alternativamente, um dos requisitos das alíneas "a", "b" e "c" do inciso I e, cumulativamente, os requisitos dos incisos II e III.

${ }^{148} \mathrm{~A}$ business judgement rule, proveniente do direito norte-americano, com base no leading case Otis \& Co v. Pennsylvania R. Co. 61 F. Supp 905 (E.D. Pa. 1945). Alexandre dos Santos de Aragão definiu o termo como: "a business judgment rule é definida como o princípio que assegura que os "os diretores das empresas são protegidos pela presunção a eles conferida pelo Direito de terem agido com boa-fé em relação aos interesses da empresa cuja gestão the foi conferida". ARAGÃO, 2017, p. 378.

${ }_{149}$ Gimbel v. Signal Cos, 316 A.2d 599, 608 (Del. Ch. 1974), apud ARAGÃO, Alexandre dos Santos de. Empresas Estatais. Rio de Janeiro: Forense. VitalBook file, 2017. p. 378.
} 
estatais, este deverá ser o seu papel, e pode-se dizer que, como mencionado em tópico anterior, representa o backlash desta jurisprudência publicista. 


\section{CONCLUSÃO}

A pesquisa realizada com base na jurisprudência do Supremo Tribunal Federal, assim como na análise doutrinária, possuiu a finalidade de expor a captura do regime publicista às estatais. Além disso, queremos demonstrar que tal entendimento deverá ser modificado, a fim de que se conclua que uma empresa estatal, independente da atividade que exerça, possui personalidade jurídica de direito privado ${ }^{150}$.

As soluções possíveis e mais adequadas para solucionar a crise no modelo jurídico das Empresas Estatais seria modificar o entendimento do Supremo Tribunal Federal, o qual concede às Empresas Estatais prestadoras de serviços públicos as prerrogativas, tais quais foram mencionadas neste trabalho, a imunidade tributária recíproca e o regime de execução da Fazenda Pública. Esta modificação do entendimento da Corte dar-se-á por meio da produção de entendimentos sumulados a partir de uma transformação de suas atitudes.

Ainda, é certo que, conforme a ocorrência da ampliação dos benefícios concedidos pela Corte, as Empresas Estatais existentes irão pleitear judicialmente estes privilégios, como já está acontecendo, sendo este um movimento cíclico. Isto faz com que elas mitiguem sua substância empresarial.

Outra forma de mitigar esta questão seria o Supremo Tribunal Federal deixar de conceder a prerrogativa de impenhorabilidade de seus bens, assim como a imunidade tributária recíproca, pois conforme tais prerrogativas forem sendo concedidas, as empresas estatais prestadoras de serviços públicos teriam sua identidade confundida com a das autarquias,

\footnotetext{
${ }^{150} \mathrm{~A}$ fim de aprofundar-se no tema acerca da compatibilidade da personalidade jurídica de direito privado das empresas estatais e a prestação de serviços públicos, cabe a leitura sugerida por PINTO, Henrique Motta; MARTINS, Humberto Falcão; CUNHA JUNIOR, Luiz Arnaldo Pereira da. p. 266, 267, 275. In: PINTO, 2010b, p. 184.
} 
que prejudicaria sua identidade como Empresa Estatal e a forma como executaria suas funções.

Neste sentido, ainda sobre possíveis soluções para a questão da tendência de captura do regime público pelas Empresas Estatais, seria a produção de novas leis que afastassem as prerrogativas concedidas a essas empresas estatais, adequando o formato empresarial pelo Estado com as necessidades decorrentes da prestação de serviço público.

Neste sentido, o ideal seria a efetiva produção de novas leis e o convencimento do Supremo Tribunal Federal de que seria uma alteração constitucional, de que a jurisprudência que fora antes consolidada pela Corte passou a gerar uma grave crise no modelo jurídico da Empresa Estatal.

A empresa estatal prestadora de serviço público está transvestida de autarquia, possui seus privilégios, são equiparadas à Fazenda Pública, e isto não vem protegendo o serviço público por ela prestado, pelo contrário, somente seu patrimônio encontra-se protegido. Esta situação prejudica àqueles que contratam com a administração pública, tornando engessada sua atuação no mercado privado.

O Estado escolheu a forma empresarial, a pessoa jurídica de direito privado, por meio das empresas estatais, para prestar os serviços públicos de forma descentralizada. Se quisesse, poderia conceder este serviço público ou mesmo criar uma autarquia, então que sejam mantidas suas características originárias, as que conferem sua própria identidade. Não reside lógica em o Estado adotar a forma empresarial, e, por conseguinte, o Supremo Tribunal Federal relativizá-la, conferindo roupagem de pessoa jurídica de direito público. Isto muito causa estranheza e na realidade, não alcança o objetivo que seria precipuamente atendido, que é o interesse público. Deve-se, portanto, atentar prioritariamente para a melhor forma de prestação de serviço pelo Estado, a fim de que seja priorizada a melhor e mais eficiente consecução do interesse público permitida pelo ordenamento. 


\section{REFERÊNCIAS BIBLIOGRÁFICAS}

ABRANCHES, Sérgio Henrique. A empresa pública como agente de políticas do Estado: Fundamentos Teóricos do seu Papel, Inclusive em Face de Nossas Relações com o Exterior. In: Seminário sobre empresas estatais. A empresa pública no Brasil: uma abordagem multidisciplinar. Brasília: IPEA, 1980.

ADI n 1642/MG, Ministro Eros Grau, Julgado em: 03 abr. 2008.

AHARONI, Yair. The Evolution and Management of State Owned Enterprises (Ballinger Series in Business and Public Policy). Ballinger Pub Co - September, 1986.

ALESSI, Renato. Institucines de Derecho Administrativo. Tomo I. Traducción dela $3^{\text {a }}$ edición italiana por Buenaventura Pellisé Prats. Barcelona: Bosch, Casa Editorial, 1970.

ARAGÃO, Alexandre dos Santos de. Curso de Direito Administrativo. Rio de Janeiro: Forense, 2012.

Curso de Direito Administrativo. $2^{\mathrm{a}}$ ed. rev. atual. e ampl. Rio de Janeiro: Forense, 2013.

Curso de Direito Administrativo. $2^{\mathrm{a}}$ ed. rev. atual. e ampl. Rio de Janeiro: Forense, 2013. p. 124. In: ARAGÃO, Alexandre dos Santos de. Empresas Estatais. Rio de Janeiro: Forense. VitalBook file, 2017.

- Empresas Estatais: O Regime Jurídico das Empresas Públicas e Sociedades de Economia Mista. 1. ed. - São Paulo: Forense, 2017.

ARAÚJO, Edmir Netto de. Curso de Direito Administrativo. São Paulo: Saraiva, 2010.

ATALIBA, Geraldo. Sabesp. Serviço público. Delegação a empresa estatal, Imunidade a impostos. Regime de taxas In: Revista de Direito Público RDP. v. 92. p. 89, 1989 In: ARAGÃO, Alexandre dos Santos de. Empresas Estatais. Rio de Janeiro: Forense. VitalBook file, 2017.

BAINBRIDGE, Stephen M. Interpreting nonshareholder constituency statutes. Pepperdine Law Review. v. 19, 1992. Disponível em: <http://ssrn.com/abstract=310261>. Acesso em: 12 jan. 2007. In: PINTO 
JUNIOR, Mario Engler. Empresa Estatal: função econômica e dilemas societários. $2^{\mathrm{a}}$ ed. São Paulo: Atlas, 2013.

BORGES, Alice Gonzalez. Impenhorabilidade de Bens. Sociedade de Economia Mista Concessionária de Serviços Portuários. Bens afetados à Prestação de Serviço Público. Revista Eletrônica de Direito Administrativo - REDAE. n. 11, 2007. p. 2-13. Disponível em:

<http://www.direitodoestado.com/revista/REDAE-11-AGOSTO-2007ALICE\%20GONZALEZ.pdf>. Acesso em: 13 fev. 2012.

BRASIL. Código Civil, Lei 10.406, de 10 de janeiro de 2002. Disponível em:

<http://www.planalto.gov.br/ccivil_03/leis/2002/L10406compilada.htm>. Acesso em: 15 mai. 2017.

BRASIL. Constituição da República Federativa do Brasil de 1988. Disponível em:

<http://www.planalto.gov.br/ccivil_03/constituicao/constituicaocompilado. htm>. Acesso em: 21 mai. 2017.

CARVALHO FILHO, José dos Santos. Manual de Direito Administrativo. $18^{\mathrm{a}}$ ed. Rio de Janeiro: Lumen Juris, 2008. p. 447 In: FIDALGO, Carolina Barros. O Estado empresário: regime jurídico das tradicionais e novas formas de atuação empresarial do estado na economia brasileira. Rio de Janeiro. 2012. 370 f. p. 166. Dissertação de Mestrado em Direito Faculdade de Direito, Universidade do Estado do Rio de Janeiro, 2012.

CARVALHOSA, Modesto. As poison pills estatutárias na pratica brasileira - alguns aspectos de sua legalidade. In: CASTRO, Rodrigo R. Moteiro de; ARAGÃO, Leandro Santos de (Coord.). Direito societário: desafios atuais. São Paulo: Quartier Latin, 2009.

COMPARATO, Fabio Konder. A reforma da empresa. Revista de Direito Mercantil, Industrial, Econômico e Financeiro. Nova Série, a. 22, n. 50, p. 63, abr./jun. 1983.

Aspectos Jurídicos da Macroempresa. São Paulo: Revista dos Tribunais, 1970.

. Sociedade de economia mista transformada em sociedade anônima ordinária - inconstitucionalidade. Revista trimestral de direito público. Instituto Internacional de Direito Público. Instituto de Direito Administrativo Paulista. São Paulo: Malheiros Editores, 1993. 
; SALOMÃO FILHO, Calixto. O Poder de Controle na Sociedade Anônima (com Salomão Filho, Calixto). $4^{\mathrm{a}}$ ed. São Paulo: Editora Forense, 2005.

; _ $\quad$ O Poder de Controle na Sociedade Anônima (com Salomão Filho, Calixto). 4a ed. São Paulo: Editora Forense, 2005 In: PINTO JUNIOR, Mario Engler. Empresa Estatal: função econômica e dilemas societários. $2^{\mathrm{a}}$ ed. São Paulo: Atlas, 2013.

COSTA, Regina Helena. Imunidades Tributárias: teoria e análise da jurisprudência do STF. São Paulo: Malheiros Editores, 2001. p. 144-145 In: ARAGÃO, Alexandre dos Santos de. Empresas Estatais. Rio de Janeiro: Forense. VitalBook file, 2017.

DALLARI, Adilson Abreu. O Controle Político das Empresas Públicas. In: A Empresa Pública no Brasil: uma abordagem multidisciplinar. Brasília: IPEA, 1980. p. 184. apud FIDALGO, Carolina Barros. O Estado empresário: regime jurídico das tradicionais e novas formas de atuação empresarial do estado na economia brasileira. Rio de Janeiro. 2012. $370 \mathrm{f}$. p. 166. Dissertação de Mestrado em Direito. Faculdade de Direito, Universidade do Estado do Rio de Janeiro, 2012.

DI PIETRO, Maria Sylvia Zanella. Direito Administrativo. 22 ed. São Paulo: Atlas, 2008. p. 461.

Diário Oficial da União. 29 jun. 2009. Disponível em: <http://www.cvm.gov.br/legislacao/pare/pare036.html>. Acesso em: 31 mar. 2017.

EIZIRIK, Nelson et al.. Mercado de Capitais: Regime Jurídico. São Paulo: Renovar, 2008.

FERREIRA JUNIOR, Celso Rodrigues. Do Regime de Bens das Empresas Estatais: Alienação, Usucapião, Penhora e Falência In: SOUTO, Marcos Juruena Villela (Coord.). Direito Administrativo Empresarial. Rio de Janeiro: Lumen Juris, 2006.

FIDALGO, Carolina Barros. O Estado empresário: regime jurídico das tradicionais e novas formas de atuação empresarial do estado na economia brasileira. Rio de Janeiro. 2012. 370 f. p. 166. Dissertação de Mestrado em Direito. Faculdade de Direito, Universidade do Estado do Rio de Janeiro, 2012. 
FRANCO, Vera Helena de Mello. Direito Empresarial: Sociedade Anônima. Mercado de Valores Mobiliários. v. 2. São Paulo: Revista dos Tribunais, 2014.

FURTADO, Lucas Rocha. Curso de Direito Administrativo. Belo Horizonte: Fórum, 2007.

GASPARINI, Diógenes. Direito Administrativo. $11^{\mathrm{a}}$ ed. São Paulo: Saraiva, 2006.

GILSON, Ronald J. Controlling shareholders and corporate governance: complicating the comparative taxonomy (Aug. 2005). ECGI - Law Working Paper, n. 49. Disponível em: 〈http://ssrn.com/abstract=784744〉. Acesso em: 03 abr. 2017.

Guia da Associação Brasileira de Private Equity \& Venture Capital. Disponível em: <http://www.abvcap.com.br/Download/Guias/2726.pdf>. Acesso em: 19 mai. 2017.

JUSTEN FILHO, Marçal. Comentários à lei de licitações e contratos administrativos. $17^{\mathrm{a}}$ ed. São Paulo: Revista dos Tribunais, 2016.

Curso de Direito Administrativo. 9. ed. São Paulo: RT, 2013 In: ARAGÃO, Alexandre dos Santos de. Empresas Estatais. Rio de Janeiro: Forense. VitalBook file, 2017.

O Regime Jurídico das Empresas Estatais e Distinção entre "Serviço Público" e "Atividade Econômica". In: Revista de Direito do Estado. v. 1, 2006.

MARQUES NETO, Floriano de Azevedo. As contratações estratégicas das estatais que competem no mercado. Rio de Janeiro: Lumen Juris, 2006 In: OSORIO, Fabio Medina; SOUTO, VILLELA, Marcos Juruena (Coord.). Direito Administrativo - Estudos em Homenagem a Diogo de Figueiredo Moreira Neto. Rio de Janeiro: Lumen Juris, 2006.

MEIRELLES, Hely Lopes. Direito Administrativo Brasileiro. $32^{\mathrm{a}}$ ed. São Paulo: Malheiros Editores, 2006.

MELLO, Celso Antonio Bandeira de. Curso de Direito Administrativo. 15 ed. São Paulo: Malheiros Editores, 2002.

Curso de Direito Administrativo. 25. Ed. São Paulo: Malheiros Editores, 2007. 
Prestação de serviços públicos e administração indireta. $2^{\mathrm{a}}$ ed. São Paulo: Revista dos Tribunais, 1979.

MENDONÇA, José Vicente Santos de. A Captura Democrática da Constituição Econômica. Uma proposta de releitura das atividades públicas de fomento, disciplina e intervenção direta na Economia à luz do pragmatismo e da razão pública, 2010. 485f. Tese (Doutorado em Direito) Faculdade de Direito, Universidade do Estado do Rio de Janeiro, Rio de Janeiro, 2010.

MOREIRA NETO, Diogo de Figueiredo. Curso de Direito Administrativo. $14^{\mathrm{a}}$ ed. Rio de Janeiro: Editora Forense, 2006.

MUKAI, Toshio. O Direito Administrativo e os Regimes Jurídicos das Empresas Estatais. 2. ed. Belo Horizonte: Fórum, 2004.

OCDE - Organização para a Cooperação e Desenvolvimento Econômico. Corporate Governance of Stateowned Enterprises. A Survey of OECD Countries. p. 36. Disponível em: <http://www.keepeek.com/Digital-AssetManagement/oecd/governance/corporate-governance-of-state-ownedenterprises_9789264009431-em>. Acesso em: 18 mai. 2017.

OECD - Organisation for Economic CO-operation and Development. Corporate governance in development: the experiences of Brazil, Chile, India, and South Africa. Paris: OECD Development Centre, 2003.

OECD - ORGANISATION FOR ECONOMIC CO-OPERATION AND DEVELOPMENT. Privatizing state-owned enterprises: an overview of policies and practices in OECD Countries. Paris: OECD Publications, 2003 In: PINTO JUNIOR, Mario Engler. Empresa Estatal: função econômica e dilemas societários. 2a ed. São Paulo: Atlas, 2013.

OLIVEIRA, Rafael Carvalho Rezende de. Administração Pública, Concessões e Terceiro Setor. São Paulo: Método, 2015.

Administração Pública, Concessões e Terceiro Setor. Rio de Janeiro: Lumen Juris, 2011.

Curso de Direito Administrativo. $4^{\mathrm{a}}$ ed. rev. atual. e ampl. Rio de Janeiro: Forense; São Paulo: Método, 2016.

ORTIZ, Gaspar Ariño. Principios de derecho público económico. Granada: Comares e Fundación de Estudios de Regulación, 1999. 
Principios de derecho público económico. Granada: Comares e Fundación de Estudios de Regulación, 1999 Apud ARAGÃO, Alexandre dos Santos de. Empresas Estatais. Rio de Janeiro: Forense. VitalBook file, 2017.

PAIVA, Alfredo de Almeida. As sociedades de economia mista e as empresas públicas como instrumentos jurídicos a serviço do Estado. In: Revista de Direito Administrativo (Seleção Histórica). v. 1. p. 319-320, 1991.

PINTO JUNIOR, Mario Engler. Empresa Estatal: Função Econômica e Dilemas Societários. São Paulo: Atlas, 2010.

Empresa Estatal: função econômica e dilemas societários. $2^{\mathrm{a}}$ ed. São Paulo: Atlas, 2013.

Empresa Estatal: função econômica e dilemas societários. 2a ed. São Paulo: Atlas, 2013. p. 57. In: FIDALGO, Carolina Barros. O Estado empresário: regime jurídico das tradicionais e novas formas de atuação empresarial do estado na economia brasileira. Rio de Janeiro. 2012. $370 \mathrm{f}$. p. 166. Dissertação de Mestrado em Direito - Faculdade de Direito, Universidade do Estado do Rio de Janeiro, 2012.

Estado como acionista controlador. Tese de Doutorado. Orientador: Prof. Calixto Salomão Filho. Faculdade de Direito da USP, 2009.

PINTO, Henrique Motta. A autarquização das Empresas Estatais na jurisprudência do Supremo Tribunal Federal: um obstáculo para as reformas na administração pública. v. 15. n. 57. São Paulo: Cadernos de Gestão Pública e Cidadania, 2010a.

Empresas estatais: modelo jurídico em crise? São Paulo, 2010. Dissertação de Mestrado. Orientador: Carlos Ari Sundfeld. Pontifícia Universidade Católica de São Paulo. 2010b.

; MARTINS, Humberto Falcão; CUNHA JUNIOR, Luiz Arnaldo Pereira da. p. 266, 267, 275. In: PINTO, 2010 b.

RE 220.906/DF, Plenário, Rel. Ministro Maurício Corrêa, Julgado em: 16 de novembro de 2000.

RE 225.011/MG, Plenário, Rel. Ministro Marco Aurélio, Redator para Acórdão Ministro Maurício Corrêa Julgado em: 16 nov. 2000. 
RE 229.696/PE, Plenário, Rel. Ministro Ilmar Galvão, Redator para Acórdão Ministro Maurício Corrêa, Julgado em: 16 nov. 2000.

RE 230.051/SP, Plenário, Rel. Ministro Ilmar Galvão, Redator para o Acórdão Ministro Maurício Corrêa, Julgado em: 6 nov. 2000.

RE 230.072/RS Plenário, Rel. Ministro Ilmar Galvão, Redator para o Acórdão Ministro Maurício Corrêa, Julgado em: 16 nov. 2000.

ROLIM, Luis Antonio. A Administração Indireta, as Concessionárias e Permissionárias em Juízo. Características das autarquias, empresas públicas, sociedades de economia mista, fundações públicas e dos particulares em colaboração com o Estado. São Paulo: RT.

ROSILHO, André. Licitação no Brasil. São Paulo: Malheiros Editores, 2013.

SALOMÃO FILHO, Calixto. Regulação e desenvolvimento. In: SALOMÃO FILHO, Calixto (Org.). Regulação e desenvolvimento. São Paulo: Malheiro, 2002.

Sociedade anônima: interesse público e privado. Interesse Público. v. 5, n. 20, jul. Belo Horizonte, 2003.

SILVA, Rodrigo Crelier Zambão da. A captura das estatais pelo regime jurídico de Direito Público: algumas reflexões In: ARAGÃO, Alexandre Santos de (Coord.). Empresas públicas e sociedades de economia mista. $1^{\mathrm{a}}$ ed. Belo Horizonte: Fórum, 2015.

SMITH, Adam. An inquiry into the nature and causes of the wealth of nations. Cambridge: Hackett publishing Company, 1993.

SOUTO, Marcos Juruena Villela. Direito Administrativo da Economia. Rio de Janeiro: Lumen Juris, 2003.

Direito Administrativo Empresarial. Rio de Janeiro: Lumen Juris, 2006.

STF, Ação Civil Originária 571, AgRg/SP, Relator Ministro Dias Toffoli, Plenário, Julgado em: 07 de março de 2017.

STF, Ação Civil Originária 811, AgRg/DF, Relatora Ministra Rosa Weber, Primeira Turma, Julgado em: 21 de junho de 2016. 
STF, ACO 571, AgRg/SP, Rel. Ministro Dias Toffoli, Plenário, Julgado em: 07 mar. 2017.

STF, ACO 811, AgRg/DF, Rel. Ministra Rosa Weber, Primeira Turma, Julgado em: 21 jun. 2016.

STF, Agravo Regimental em Ação Cível Originária no 2730, Plenário. Rel. Ministro Edson Fachin, Julgado em: 07 mar. 2017.

STF, MS n ${ }^{\text {o } 26297 / D F . ~ S e g u n d a ~ T u r m a . ~ R e l . ~ M i n i s t r o ~ E d s o n ~ F a c h i n, ~}$ Julgado em: 16 mar. 2017.

STF, RE no 172.816/RJ, Plenário, Rel. Ministro Paulo Brossard, Julgado em: 09 fev. 1994.

STF, RE $n^{\text {o }}$ 285.716 AgRg, 2 ${ }^{\text {a }}$ Turma, Rel. Ministro Joaquim Barbosa, Julgado em: 02 mar. 2010.

STF, RE no 363.412 Agravo Regimental, 2a Turma, Rel. Ministro Celso de Mello, Julgado em: 07 ago. 2007.

STF, RE no 599.628/DF, Plenário, Rel. Ministro Ayres Britto, Julgado em: 25 mai. 2011.

STF, Tribunal Pleno, MS 24.423/DF, Rel. Ministro Gilmar Mendes, Julgado em: 20 fev. 2009, Informativo de Jurisprudência do STF nº 519.

STF, Tribunal Pleno, MS 25.092/DF, Rel. Ministro Carlos Velloso, Julgado em: 17 mar. 2006.

SUNDFELD, Carlos Ari. (Coord.). Parcerias Público-Privadas. $2^{\mathrm{a}}$ ed. São Paulo: Direito GV, Malheiros Editores, 2011.

A participação privada nas empresas estatais. In: Direito administrativo econômico. São Paulo: Malheiros Editores, 2000.

Direito Administrativo Para Céticos - $2^{\mathrm{a}}$ ed. São Paulo: Malheiros Editores, 2014.

O Direito Administrativo entre os clipes e os negócios. In: ARAGÃO, Alexandre dos Santos de; MARQUES NETO, Floriano de Azevedo (Coord.). Direito Administrativo e seus novos paradigmas. Belo Horizonte: Fórum, 2008. 
; SOUZA, Rodrigo Pagani de. Licitação nas Estatais: Levando a Natureza Empresarial a Sério. In: Revista de Direito Administrativo. $\mathrm{n}^{\mathrm{o}} 245$, 2007.

SUNSTEIN, Cass R. A Constitution of Many Minds: why the founding document doesn't mean what it meant before? Princeton: Princeton University Press, 2009 apud WILLEMAN, Marianna Montebello. Constitucionalismo Democrático, Backlash e Resposta Legislativa em Matéria Constitucional no Brasil. 33 ${ }^{\mathrm{a}}$ ed. REDE. jan/fev/mar 2013.

TORRES, Ricardo Lobo. Tratado de Direito Constitucional, Financeiro e tributário. v. III. Rio de Janeiro: Renovar, 2005. p. 491 In: FIDALGO, Carolina Barros. O Estado empresário: regime jurídico das tradicionais e novas formas de atuação empresarial do estado na economia brasileira. Rio de Janeiro. 2012. 370 f. p. 166. Dissertação de Mestrado em Direito Faculdade de Direito, Universidade do Estado do Rio de Janeiro, 2012.

WILlEMAN, Marianna Montebello. Constitucionalismo Democrático, Backlash e Resposta Legislativa em Matéria Constitucional no Brasil. 33a ed. REDE. jan/fev/mar 2013. 